UNIVERSIDADE DE SÃO PAULO

FACULDADE DE FILOSOFIA, LETRAS E CIÊNCIAS HUMANAS

DEPARTAMENTO DE FILOSOFIA

PROGRAMA DE PÓS-GRADUAÇÃO EM FILOSOFIA

HENRIQUE DE MORAIS RIBEIRO

Monadismo e Fisicismo:

Um Ensaio sobre as Relações Mente-Corpo 
HENRIQUE DE MORAIS RIBEIRO

\section{Monadismo e Fisicismo: Um Ensaio sobre as Relações Mente-Corpo}

Tese de doutorado apresentada ao programa de Pós-Graduação em Filosofia do Departamento de Filosofia da Faculdade de Filosofia, Letras e Ciências Humanas da Universidade de São Paulo, para defesa sob a orientação do Prof. Dr. Osvaldo Frota Pessoa Júnior. 


\section{Agradecimentos}

Iniciei meus estudos na Filosofia no curso de graduação da Universidade Estadual Paulista “Júlio de Mesquita Filho" em 1993. Desde então até 1996, eu fui convidado para fazer parte do Grupo Acadêmico "Estudos Cognitivos" onde tive contato com muitas pessoas que me ajudaram a aprimorar meu interesse pela Filosofia. As discussões interdisciplinares do GAEC abrangiam muitas áreas, tais como: Inteligência Artificial, Neurociência Cognitiva, Linguística Computacional e principalmente, questões de Filosofia da Mente. Fui introduzido por colegas no GAEC e devo aos professores e colegas de pesquisa a oportunidade de começar minhas discussões sobre questões filosóficas sobre a natureza da mente.

Depois de completar meus estudos de graduação, continuei na Faculdade de Filosofia e Ciências da UNESP, juntando-me ao programa de mestrado. Neste curso, continuei a ter a oportunidade de participar do GAEC de 1997 a 2000, quando então defendi minha dissertação de mestrado no campo da Filosofia da Ciência, aplicando resultados desta área no campo da Ciência Cognitiva, focalizando a questão da interdisciplinaridade nesta ciência. No trabalho com esta questão, tive a chance de me corresponder com Hilary Whitehall Putnam, que contribuiu para o entendimento de muitas questões sobre a teoria funcionalista da relação mente-corpo na Filosofia da Mente contemporânea. 
Quando completei meu mestrado, decidi fazer parte de meus estudos no exterior, para aprimorar meu doutorado e para focalizar meus interesses na Filosofia da Mente, escolhendo como tópico da tese o problema mente-corpo.

Após realizar alguns estudos de doutorado sobre filosofia das neurociências, semiótica e filosofia da mente no programa de doutorado da Universidade Estadual Paulista no ano de 2000, iniciei, então, uma pesquisa prospectiva sobre agências de fomento à pesquisa doutoral, bem como sobre programas de doutorado em universidades nos Estados Unidos, Inglaterra, França e Austrália, durante os anos de 2000 a 2002. Obtive, nesta fase, como resultado, uma bolsa da CAPES - Ministério da Educação em 2002, para doutorado pleno ou estágio doutoral, e uma vaga incondicional para o programa de doutorado no departamento de filosofia da Universidade de Sheffield e uma vaga condicional para University College London, com a colaboração de Antônio Trajano de Menezes Arruda, da UNESP e Donald Peterson, do Institute of Education da Universidade de Londres. Despendi dois anos acadêmicos - 2002 a 2004 - nos departamentos de Filosofia das Universidades de Sheffield e, posteriormente, em Londres, King's College.

Nestes lugares, pude realizar o levantamento bibliográfico em diversas bibliotecas e redigir a estrutura principal do argumento central da tese e me corresponder com acadêmicos de várias universidades nos exterior trabalhando em minha área de pesquisa, dentre os quais destaco: Peter Simons, Donald Davidson, Jaegwon Kim, Hilary Putnam, Steven Stich e David Chalmers.

Parte da crítica de versões preliminares do trabalho desta tese deve-se principalmente ao professor Christopher Hookway da Universidade de Sheffield, na sessão acadêmica de 2002-2003. Menciono também posteriormente James Hopkins e Keith Hossack, cujos comentários me levaram a discutir o emergentismo, Verity Hartle 
(atualmente em Yale), pelas discussões sobre a relação de superveniência para domínios múltiplos, e David Papineau, todos do departamento de filosofia de King's College. Nesta universidade, tive a chance de participar dos seminários avançados e de pesquisar na biblioteca principal da Universidade de Sheffield, no Maugham Library do King's College, e na Biblioteca Britânica. Meu trabalho nesta tese foi apoiado teoricamente pelos encontros de pesquisa nos seminários no King's College durante as sessões acadêmica de 2003-2004. Sou grato aos colegas da pós-graduação dos departamentos de Sheffield e King's College pelos comentários e sugestões, menciono David Liggins, Elizabeth Schellekens e Jake Chandler, atualmente nas Universidades de Manchester, Durham e Glasgow respectivamente.

As ideias intuitivas que sustentam o argumento explicativo da relação mente-corpo aqui desenvolvido são um trabalho em progresso, principalmente no que tange à derivação das implicações científicas dos pressupostos deste ensaio. Penso que meu trabalho concorda, em certa medida, com assunções e motivações filosóficas específicas das abordagens contemporâneas da relação mente-corpo em Thomas Nagel, o qual propôs uma teoria panpsiquista da mente, e David Chalmers, o principal, senão maior, propositor de uma teoria fenomenológica da subjetividade da mente, abordagens estas que primam pela relevância causal da mente na explicação das relações mente-corpo.

Com relação a comentários mais profundos de versões preliminares do manuscrito, menciono Hans Burkhardt e Cristina Schneider, ambos do departamento de filosofia da Universidade de Munique. Menciono também Gordon Globus, da Universidade da Califórnia em Irvine, que, em 2006, fez comentários substanciais sobre as versões preliminares do manuscrito, principalmente a respeito da discussão sobre o físicismo contemporâneo e sobre o dualismo elementar. Michael Esfeld, da Universidade de 
Lausanne, teceu comentários sobre a premissa composicional holística do argumento proposto. Eles seguramente contribuíram para a compreensão da linha de argumentação, situável na Filosofia Antiga (tradições egípcia, grega e judaica), porém também ainda nova, que denomino "monadismo", o qual é um estudo ontológico, isto é, no dizer de Aristóteles

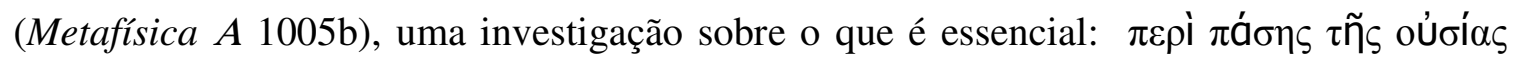
$\theta \varepsilon \omega \rho \circ \tilde{v} v \tau \circ \varsigma$.

Hodiernamente, existe um interesse crescente na linha de argumentação conhecida como panpsiquismo, recentemente desenvolvida por Thomas Nagel, William Seager e Galen Strawson (o qual desenvolveu uma vertente materialista-panpsiquista denominada "monismo ou fisicismo realista"), na filosofia da mente contemporânea. No que se refere à ideia de que as propriedades mentais são ontologicamente ubíquas, temos o aspecto panpsiquista do monadismo aqui proposto. Esta visão de um universo mental constitui uma doutrina que se origina nas tradições hermética, cabalista, na de Giordano Bruno, Condillac, Leibniz, Kant (pré-crítico e leibniziano), Herbart, Husserl, Renouvier, Bradley e muitos outros filósofos monadistas cujos trabalhos serão por nós abordados oportunamente.

Agradeço a Osvaldo Frota Pessoa Júnior, meu atual orientador na Universidade de São Paulo, a Maria Eunice Quilici Gonzales, da UNESP, aos membros da banca examinadora, bem como a outros colegas, amigos e familiares e aos docentes do Departamento de Filosofia da USP por comentários e colaboração conclusiva para o aprimoramento da redação final da tese. $\mathrm{Na}$ atenuação das dificuldades da vida, menciono dentre os amigos e colegas da FFC-UNESP, Arnaldo Cezar Leite, Cacilda Satie Mori (Escola "Educação e Cultura" de Pompéia), Thiago, Tenente Mario Sergio Nonato, e 
Gabriel Rocha, os quais me acompanharam ao longo de sete anos de visita ao departamento de Filosofia da UNESP.

Para concluir, meus agradecimentos também se dirigem aos meus colegas da graduação e da pós-graduação FFC-UNESP, pela oportunidade de lecionar inglês instrumental, filosofia da mente, e filosofia da ciência durante o período de agosto 2007 ao presente ano, e pelas discussões filosóficas durante os anos acadêmicos de agosto de 2005 até o presente ano, período que se seguiu ao meu regresso do estágio doutoral no exterior.

Agradecimentos são também dirigidos às fundações CAPES e, principalmente, à FAPESP pelo apoio financeiro e assessoria durante os anos acadêmicos de 2002-2004 e 2009-2011 para meus projetos de pesquisa sobre a metafísica da relação mente-corpo na tradição pós-analítica contemporânea, ou seja, para a pesquisa e desenvolvimento relativos à área de Filosofia da Mente. 


\section{RESUMO}

Nesta tese, desenvolve-se um argumento explicativo da relação mente-corpo fundamentada na noção de mônada, ou substância simples, como elemento ontológico estruturante de um enfoque contemporâneo da mencionada relação. Na primeira parte da tese, de natureza crítica, analisam-se as teorias fisicistas contemporâneas da mencionada relação, a saber, a teoria de superveniência da mente, da emergência e da causação mental, com vistas a justificar a proposta de assunção de uma premissa dualista que visa, principalmente, propor, em contraste com o cenário epifenomenalista do fisicismo contemporâneo, uma ontologia da mente que seja compatível com as intuições realistas do senso comum e da psicológica popular sobre a força causal da mente no universo físico. Na segunda parte, de natureza positiva, propõe-se um argumento explicativo da relação mente-corpo partindo-se, para tanto, de uma assunção e duas premissas. A assunção afirma que a mente tem o mesmo importe ontológico da matéria física, sendo estes considerados como elementos composicionais, afirmação a qual se denomina dualismo elementar. No que se refere às premissas, propõe-se duas, a saber, a tese composicional holística, que afirma que a mente e a matéria são partes constitutivas de um todo chamado substância simples, e a tese composicional mereológica, que afirma que as substâncias simples ou mônadas compõem mereologicamente, por superveniência, a relação mente-corpo. Examinam-se também algumas objeções ao argumento monadista proposto.

Palavras-chave: Relação Mente-Corpo, Debate Mente/Corpo, Problema Mente-Corpo, Mônada, Monadismo, Fisicismo, Causação Mental, Emergentismo, Superveniência da Mente, Mereologia, Holismo, Dualismo, Filosofia da Mente Contemporânea. 


\begin{abstract}
This thesis offers an explanatory argument concerning the mind-body relation, an argument that is grounded on the notion of monad, or the simple substance, as an ontological element for proposing a contemporary approach to the mind-body relation. In the first part, a critique of the current physicalist theories of mind is given, namely, supervenience, emergence and mental causation, in order to justify the proposal of a dualist premiss which aims at an ontology of mind which satisfies the realistic intuitions of common sense and of folk psychology on the causal efficacy and relevance of the mind amid the physical, in opposition to the epiphenomenalist view of contemporary physicalist theories. In the second part, the positive one, we propose an explanatory argument for monadism about mind-body relations, based on an assumption and two premises. The assumption says that the mind has the same ontological import of the physical matter, and they, mind and matter, are considered to be elements entering the composition of psychophysical relations, an assumption called elementary dualism. Regarding the premises, we propose two, namely, the holistic compositional thesis, which asserts that mind and matter are parts entering the composition of true wholes called substances, and the mereological compositional thesis, which says that such simple substances compose, via supervenience, the mind-body relations. Some objections to the proposed monadist argument are examined and rejoindered as well.
\end{abstract}

Key-words: Mind-Body Relation, Mind/Body Debate, Mind-Body Problem, Monad, Monadism, Physicalism, Mental Causation, Emergentism, Epiphenomenalism, Supervenience of Mind, Mereology, Holism, Dualism, Contemporary Philosophy of Mind. 
Um mistério singular reside sob uma imensa variedade de trabalho atual na filosofia. A física descreve todo o mundo, mas parece retratar uma imagem sem qualquer pensamento neste mundo. No entanto, estamos aprendendo mais e mais como um sistema físico poderia agir se tivesse pensamentos; estamos aprendendo como uma seleção natural e a dinâmica ecológica poderiam produzir organismos para os quais atribuiríamos pensamentos sem hesitação. Presumivelmente, somos tais organismos. Ainda assim, entre descrever um organismo como um sistema físico complexo, um produto de seleção natural e de padrões de impacto ambiental tal, e, de um outro lado, dizer que isto é ter certos pensamentos, parece haver um grande abismo.

Allan Gibbard (2003, p. 83)

Pois, se não é literalmente verdadeiro que meu desejo é causalmente responsável pela minha busca, e minha coceira é causalmente responsável pelo meu ato de coçar, e minha crença é causalmente responsável por uma afirmação... se nenhuma destas é literalmente verdadeira, então praticamente tudo em que acredito sobre qualquer coisa é falso e isto é o fim do mundo.

Jerry Fodor (1989, p. 78)

Um número impressionante de filósofos sustenta que os estados mentais estão pobremente posicionados para causar conduta.

Stephen Yablo (2003, p. 316),

A forma deste argumento poderia dar margem a mal entendidos. Não é que tenhamos, por um lado, um sistema conceitual, que nos coloque diante do problema da identificação de coisas singulares; enquanto, por outro lado, existiriam objetos materiais de modo suficientemente rico e rigoroso para tornar possível a solução de tais problemas. $O$ problema existe apenas porque uma solução é possível. O mesmo é válido para todos os argumentos transcendentais.

Peter Strawson

Duma maneira semelhante aos antigos que tinham a habilidade de dirigir oito cavalos atrelados numa carruagem, Leibniz dirigiu todas as ciências numa mesma direção.

Homenagem de Fontenelle a Leibniz

Redeunt Saturnia regna

Virgílio, Quarta Écloga 


\section{Sumário}

$\begin{array}{ll}\text { Introdução } & 11\end{array}$

Cap. I - A Assunção do Dualismo Elementar e o Fisicismo Não-Reducionista 18

1 - O Dilema Atual do Fisicismo Não-Reducionista 19

2 - Os Argumentos de Superveniência Psicofísica Extraídos do Funcionalismo 22

3 - Argumentos Emergentistas das Ciências Especiais 37

4 - O Argumento de Superveniência para o Epifenomenalismo e a Causação Descendente 45

5 - Sobredeterminação Causal e Escolha 53

6 - Uma Justificação da Escolha do Dualismo Elementar 57

Cap. II - A Tese Composicional das Relações Psicofísicas 61

1 - A Tese Holista ou o Holismo dos Simples 63

2 - A Tese Mereológica ou a Mereologia dos Compostos 70

Cap. III - A Tese Ontológica das Relações Psicofísicas 82

1 - A Substância Simples ou Mônada

2 - As Substâncias Compostas 88 
1 - Posição da Tese do Monadismo 992

2 - Monadismo e Fisicismo: Similaridades e Divergências $\quad 94$

3 - Monadismos Clássicos de Leibniz e Whitehead 98

3.1 - Leibniz $\quad 99$

$\begin{array}{ll}3.2-\text { Whitehead } & 105\end{array}$

Cap. V - Objeções ao Monadismo 111

1 - Objeção sobre as Formas ou Universais $\quad 111$

2 - Dualismo Elementar: Categorias e Elementos 113

3 - Monadismos Clássico e Contemporâneo 114

4 - Discussão sobre a Janela das Mônadas 116

$\begin{array}{ll}\text { Considerações Finais } & 118\end{array}$

Referências Bibliográficas $\quad 119$ 


\section{Introdução}

As relações entre o mental e o físico ocorrem comumente no mundo. Os movimentos corporais, as sensações corporais e afecções, as dores e percepções e outras relações psicofísicas são acontecimentos naturais e comuns que relacionam a mente com os corpos físicos. Esta visão pressupõe uma certa concepção realista ingênua, comum a diversas imagens científicas do real, a respeito do que seja "corpo físico" no mundo. Na parte da Filosofia que trata do debate sobre a relação mente-corpo, existem muitas questões de longa data em discussão sobre as relações psicofísicas. Questões comumente levantadas pelo senso comum e também no domínio das ciências psicológicas são: O que é a mente? O que é o corpo físico? Como eles estão relacionados? Em que medida nossas intuições do senso comum são corretas?

$\mathrm{Na}$ Ontologia da Mente, muitas interpretações das questões referidas e suas respectivas respostas têm sido propostas com vistas a explicar as relações psicofísicas. Como sabemos ao percorrer a literatura em Filosofia da Mente, é possível colocar as respostas, visões e posições em diferentes classes de argumentos cujos fundamentos ontológicos são expressos em premissas que variam do dualismo cartesiano até as formas contemporâneas do fisicismo ${ }^{1}$. Em uma tal classe, as questões são levantadas e visões são sugeridas para a acepção dos termos "mental" e "físico", e para a explicação de como eles estão relacionados. Neste ensaio, argumentarei a favor de uma posição realista não fisicista, não cartesiana, mas "monadista".

\footnotetext{
${ }^{1}$ Usarei o termo "físicismo", e não "fisicalismo", como tradução de physicalism, para me referir à corrente do materialismo sobre a relação mente-corpo na tradição analítica contemporânea.
} 
Muitos filósofos têm recentemente argumentado em favor de posicionamentos fisicistas, posicionamentos estes que podem ser vistos como variedades de argumentos para explicação das relações mente-corpo. Tais variedades têm sido propostas com vistas a estruturar a formulação adequada do problema mente-corpo e sugerir respostas possíveis às questões às quais nos referimos anteriormente. Os argumentos materialistas parecem ter assumido pressupostos mais fortes sobre a realidade causal da mente; muitas visões fisicistas recentemente propostas sobre as relações mente-corpo têm posicionamentos, afirmativas e assunções que têm sido formuladas com vistas a argumentar em favor do realismo mental, uma doutrina de acordo com a qual a mente tem influência causal sobre o físico.

O debate sobre o problema mente-corpo parece indicar que, de modo a eliminar algumas dificuldades dos argumentos fisicistas (principalmente aquelas que se relacionam com a intuição do senso comum de que a mente altera o mundo), uma abordagem nova e mais forte da ontologia da mente se faz necessária, assim como um pedido filosófico pela eficácia causal da mente. O desideratum de uma tal ontologia da mente (no qual a mente tem influência real sobre o mundo) é certamente compartilhado pelos argumentos de diversas teorias da mente contemporâneas, tais como o fisicismo não-reducionista, funcionalismo, panpsiquismo, mentalismo e emergentismo. Ele é negado apenas por formas reducionistas e eliminativistas do fisicismo.

Com o propósito de mostrar como uma ontologia realista alternativa (não fisicista) poderia ser desenvolvida, preservando a intuição da psicologia popular (folk psychology) de que a mente tem eficácia causal, objetivamos, neste ensaio, argumentar em favor da explicação da relação mente-corpo com base em duas estratégias. Primeiramente, discordamos em parte das teses ontológicas de superveniência da mente e de emergência da 
mente defendidas pelo fisicistas. Em segundo lugar, defendemos uma teoria chamada pela tradição filosófica de monadismo ou substancialismo ${ }^{2}$ sobre a relação mente-corpo. Com vistas a satisfazer o desideratum anteriormente mencionado, eu proporei uma resposta com base em assunções monadistas, usadas para formular o problema mente-corpo. Trata-se de assunções tácitas, e não de suposições empiricamente testáveis (ou seja, pretendo fazer algo como uma filosofia primeira, e não uma metafísica naturalizada). Tais assunções referemse à noção de substância simples, a mônada, que são usadas como fundamento para a formulação de conceitos no contexto de uma abordagem monadista (sob aspecto programático) do problema mente-corpo. Pressuponho a existência de universais, ou seja, um realismo de universais, e a mônada é entendida como um universal.

Além disso, neste ensaio, eu alego que a mente e a matéria relacionam-se entre si como elementos que compõem e constituem "compostos psicofísicos". Os elementos supramencionados são definíveis ontologicamente como unidades monádicas do ser, e toda relação mente-corpo sobrevém (ou "supervém") à agregação desses unidades monádicas.

Para defender o substancialismo ou monadismo como formulações e soluções propostas para o problema mente-corpo, considerarei as questões relevantes tocantes às visões fisicistas, e argumentarei diretamente em favor de uma ontologia mais forte e em favor da realidade causal da mente em meio ao mundo físico. Em vez de argumentar em favor da primazia do universo material - a ideia expressa na tese ontológica de que o que existe é o universo físico, tal como se faz na defesa do fisicismo mínimo -, alego que deveríamos dar à mente o mesmo importe ontológico da matéria, de modo a oferecer uma

\footnotetext{
${ }^{2}$ Neste ensaio, eu utilizarei o termo "monadismo" tal como na acepção proposta por Russell ([1937] 1997), na colocação da questão da existência e do conhecimento dos universais ou formas, com certas distinções de significado e de posição, e por Eliot (1916). Utilizarei o termo "monadismo" como sinônimo dos termos "substancialismo" ou "substancialismo monádico".
} 
explicação da relação mente-corpo que satisfaça os desiderata ontológicos das discussões em Filosofia da Mente. O caminho da igualdade no importe ontológico será o fundamento da estratégia deste ensaio.

$\mathrm{O}$ argumento central deste ensaio resulta da conjunção de três premissas e uma tese principal sustentada por tais premissas. A primeira premissa é a assunção do dualismo elementar. Segundo tal assunção, os termos "mente" e "matéria" são interpretados segundo a categoria metafísica de elementos (stoikeia para os antigos gregos), que têm a mesma importância ontológica na explicação da relação mente-corpo.

A segunda premissa é a tese composicional mereológica, que afirma que a mente e a matéria do mundo físico compõem mereologicamente, por meio de superveniências, os seres pensantes existentes. Uma relação mereológica, ou quantitativa, é uma relação entre parte e todo, em que as partes têm uma prioridade ontológica sobre o todo. Por exemplo, um monte de trigo nada mais é do que um agregado de grãos de trigo; pode-se dizer que o todo é a soma das partes. Esta é uma composição mereológica. Mas há um outra espécie de composição, que é a composição holística, em que o todo tem prioridade ontológica sobre as partes. O dictum do holismo é que o todo é maior do que a soma das partes (Nagel, 1961).

Assim, a terceira premissa é a tese de que a mente e a matéria constituem uma unidade substancial indestrutível, entendendo-se por "indestrutível" aquilo cuja possibilidade de ser nada-em-absoluto não existe (seguindo a ontologia leibniziana). Chamo esta terceira premissa de tese ontológica. Esta unidade substancial é denominada "mônada". A mônada não tem partes mereológicas, apenas partes constitutivas. Um outro aspecto desta premissa é a tese de que a mente e a matéria são partes constitutivas de um 
todo holístico, sendo "holístico" definido segundo uma teoria analítica recentemente proposta por Esfeld (1998) e Simons (2003).

A tese principal do ensaio, a tese do monadismo, afirma que a mente e a matéria estão relacionadas como elementos que constituem ontologicamente um todo denominado substância ou mônada (em outras palavras, os elementos compõem holisticamente um todo essencial). Por outro lado, uma composição mereológica de uma infinidade de mônadas geraria os corpos inanimados e animados. Argumentarei, na seção IV.1, que a natureza desta relação entre mônadas e corpos é de "superveniência".

Com base na sinopse do argumento central acima exposta, este ensaio está divido em cinco capítulos. No primeiro capítulo, eu formulo a principal assunção do argumento central, ou seja, a assunção de dualismo elementar, o qual afirma que a relação entre a mente e a matéria é uma relação entre elementos mentais e físicos. Então contrasto esta assunção com os argumentos atuais em favor do fisicismo ${ }^{3}$. Após apresentar o dilema construtivo atualmente reconhecido para o fisicismo não-reducionista, exponho os principais argumentos envolvendo as teses de superveniência e de emergência. Primeiramente, na seção I.2, discutem-se os argumentos de superveniência extraídos da teoria funcionalista da mente. A seção I.3 trata dos argumentos emergentistas extraídos de diversas fontes e a seção seguinte considera o argumento de superveniência, também chamado na literatura de master argument, em favor do epifenomenalismo e da causalidade descendente. Após examinar a questão da sobredeterminação causal, formulo, na seção I.6, uma justificativa para a escolha e proposta do dualismo elementar como assunção do argumento que será defendido ao longo do presente ensaio.

\footnotetext{
${ }^{3}$ Interessa-nos o fisicismo que versa sobre a relação mente-corpo. Há outras variedades de fisicismo que não nos interessam aqui, como por exemplo as teses fisicistas sobre cores, sobre números, etc.
} 
No segundo capítulo, reservo lugar para a exposição da tese composicional do argumento. Esta tese está divida em duas partes: a tese composicional holística e a tese composicional mereológica. A tese composicional mereológica afirma que a mente e a matéria do mundo físico compõem mereologicamente, por meio de superveniências, os seres pensantes existentes. A tese composicional holística afirma que a mente e a matéria perfazem um sistema holístico substancial dos qual eles são partes integrantes. Na seção II.1, apresento a parte holística da tese composicional, na qual formulo a noção de holismo das partes simples, como elementos básicos que compõem os todos psicofísicos. Considero minha noção de holismo como uma aplicação da noção de Michael Esfeld de sistema holístico. Na seção II.2, focalizo a parte mereológica da tese composicional. Derivo conservativamente uma teoria mereológica partindo do sistema de mereologia de Burkhardt \& Degen, o qual está fundamentado na monadologia de Leibniz e, apoiando-me nos resultados deles, eu derivo algumas teses que descrevem, de maneira semi-formal, as relações mente-corpo, segundo um estilo de clareza analítica.

No terceiro capítulo, apresenta-se a tese ontológica, que está relacionada com a tese composicional. Na seção III.1, elaboro a noção de substância simples como sendo a unidade básica da composição da relação psicofísica. A noção de substância simples depende do holismo ontológico definido na seção II.1. Na seção III.2, examino a noção de substância composta, com vistas a argumentar que todos os seres pensantes são compostos, ou substâncias compostas a partir das substâncias simples denominadas mônadas.

No quarto capítulo, exponho a tese principal deste ensaio, contrastada com as teses do fisicismo e com outras linhas de argumentação, as quais denomino "monadismos clássicos”. Portanto, na seção IV.1, explico detalhadamente a tese de que as relações psicofísicas são sobrevenientes à organização de unidades básicas do ser, as mônadas, tese 
que é contrastada com a concepção de matéria primária dos fisicistas. Com o fito de inserir o monadismo no debate contemporâneo, mostra-se que a noção de mônada proposta neste ensaio é diferente das noções de mônada propostas por filósofos com Leibniz e Whitehead, noções que foram respectivamente desenvolvidas na célebre e fecunda Monadologie e na obra Process and Reality.

No capítulo cinco, apresento respostas a quatro objeções contra a proposta monadista deste ensaio. A primeira objeção alega que a noção de mônada seria ontologicamente trivial, e envolve o debate sobre a existência e conhecimento dos universais. A segunda contesta que a noção de mônada não seria adequada para as teorias contemporâneas da mente propostas nas ciências especiais e na filosofia. A terceira alude a uma distinção necessária entre elementos e propriedades, e a quarta objeção à questão da abertura causal da mônada. Em resposta a tais objeções, argumentarei em favor da nãotrivialidade da noção de mônada e em favor do posicionamento correto do monadismo em meio do debate mente-corpo contemporâneo.

Nas conclusões, tento reconciliar o monadismo com uma certa variedade do fisicismo neutro com relação à ontologia. Tal fisicismo apoia-se em uma assunção referente a uma ontologia do universo físico que é compatível com a assunção de dualismo elementar no monadismo contemporâneo, ou seja, com a realidade da mente em um universo. 


\section{Capítulo I}

\section{A Assunção de Dualismo Elementar e o Fisicismo Não-Reducionista}

Com vistas a advogar o substancialismo ou monadismo sobre as relações mentecorpo, eu gostaria de começar com uma justificativa para a escolha da assunção de dualismo elementar com premissa do argumento proposto neste ensaio. A justificativa resulta do contraste do dualismo elementar com o fisicismo, que é a doutrina de acordo com a qual tudo é constituído e composto de matéria física. O fisicismo, assim concebido, é uma interpretação filosófico-ontólogica do que existe e do que permanece sob as mudanças. Nesta doutrina, existe uma assunção fundamental de todos os argumentos materialistas: a tese da primazia do universo físico. De acordo com a tal tese, tudo sobrevém a, ou emerge de um fundamento ontológico primário, que seria a matéria física (pressupondo, na história dos debates, uma certa concepção sobre a matéria física). A corrente mais forte do fisicismo atual é não-reducionista, negando que se possa efetuar, mesmo em princípio, uma redução completa de tudo que existe à base física ou material. Ao longo da discussão do fisicismo não-reducionista, darei relevância para a tese da primazia defendida nos argumentos para explicação das relações mente-corpo.

O dualismo elementar afirma que a mente e a matéria física devem ser concebidas como elementos que são os relata de qualquer relação psicofísica e, para o monadista, tais elementos devem ter a mesma importância ontológica para explicação desta relação. Eu interpreto a mente e a matéria física como elementos que têm propriedades e constituem uma coisa simples: a substância chamada mônada. Se esta assunção é verdadeira, a mente e o corpo não são idênticos - tal como pressuposto pelas teorias materialistas de identidade 
mente-cérebro - nem fundamentalmente distintos - tal como exigido pelas teorias dualistas (sendo a identidade ou distinção interpretadas de acordo com assunções sobre as propriedades, eventos, processos e, com maior ênfase, substâncias). As teorias fisicistas conduzem a algumas dificuldades específicas, as quais esclareceremos no desenvolvimento do presente ensaio. Na visão argumentada neste ensaio, a mente e a matéria, o repetimos, são melhor concebidas com base numa ontologia de partes (as mônadas) que constituem totalidades que, a seu turno, compõem mereologicamente os seres pensantes. Tal como pretendo argumentar, estes dois elementos (mente e corpo) têm a mesma importância ontológica na explicação das relações mente-corpo.

\section{1 - O Dilema Atual do Fisicismo Não-Reducionista}

Antes de avaliar a tese de primazia (do universo material) pressuposta pelas teorias da superveniência, emergência e da causação mental no fisicismo contemporâneo, situemos as questões explicativas da formulação e da solubilidade do problema mente-corpo. As investigações filosóficas sobre o problema mente-corpo podem ser vistas como fundamentadas em duas estratégias opostas. A primeira consiste na alegação de que o problema mente-corpo é solúvel (isto é, a relação mente-corpo pode ser explicada por meio de argumentos), assumindo-se, para tanto, sua formulação e as assunções correlatas de tal formulação. A segunda consiste na alegação de que o problema mente-corpo é insolúvel (isto é, a relação mente-corpo não pode ser explicada por meio de argumentos), tentando-se de certa forma evitá-lo por meio da recusa de aceitação de assunções e pressuposições de suas formulações. 
Na primeira estratégia, aceita-se que o problema esteja bem formulado e tenta-se resolvê-lo. O fisicismo pode ser considerado como uma posição cuja estratégia é resolver o problema mente-corpo, partindo-se de diversos argumentos em favor da tese da primazia, havendo uma gama ampla para as formulações da noção de "físico" nos debates, noção que pressupõe um realismo direto sobre o mundo, formulações que dependem das concepções de superveniência e de emergência que foram propostas na literatura sobre as relações mente-corpo.

$\mathrm{Na}$ segunda estratégia, negam-se as assunções que implicam o problema mentecorpo e, portanto, evita-se o problema. A posição de Putnam (1967), por exemplo, se aproxima desta estratégia, ao "dissolver" a formulação do problema apresentada pelos materialistas da teoria da identidade. Neste texto, ele defende uma teoria funcionalista da mente, compatível com diferentes vertentes materialistas, dualistas ou espiritualistas. Para a visão funcionalista, a abordagem da relação mente-corpo tem um aspecto programático, isto é, não se objetiva a "solução da problema da relação mente-corpo", mas sim buscar fontes a posteriori para sua abordagem colocada como hipótese empírica, o que seria uma forma de abertura da discussão sobre tal questão, favorável ao pensamento leibniziano.

Ao estabelecer minha posição substancialista, em face do caráter extremamente controverso dos debates contemporâneos sobre as relações mente-corpo, procurarei criticar as formulações do problema mente-corpo feitas pelos argumentos fisicistas, fundamentadas segundo a doutrina de superveniência e, mais recentemente, da doutrina de emergência, bem como de teses adicionais que serão especificadas ao longo do ensaio. Fazse também necessário considerar a persuasão dos atuais argumentos contra a causalidade descendente. No que se segue, eu exporei e abordarei as assunções ontológicas que, na minha visão, parecem ser questionáveis. Concordarei em parte com as assunções e 
pressuposições de três classes cruciais de argumentos para o fisicismo, com vistas a justificar a escolha do dualismo elementar como assunção proposta para meu argumento de explicação das relações mente-corpo.

Entretanto, a escolha pelo dualismo não nos exclui do debate fisicista contemporâneo. O dualismo é uma possibilidade reconciliável com uma variedade de fisicismo neutro com relação à ontologia, o qual chamarei de "fisicismo neutro". O dualismo pode ser um notável resultado de tal discussão, tal como podemos ler no seguinte argumento de Jaegwon Kim, que é um momento crucial do debate:

Se os fisicistas não-reducionistas aceitam o fechamento causal do domínio físico, então, eles não têm caminho visível de lidar com a possibilidade da causação psicofísica. Isto significa que eles devem ou abandonar seu antirreducionismo ou, se não isto, rejeitar a possibilidade de relações causais psicofísicas. A negação da causação psicofísica pode surgir de duas formas: primeiro você faz tal negação porque não acredita que haja eventos mentais; ou, segundo, você mantém sua crença nos eventos mentais mesmo não aceitando que eles entrem em transações causais com os processos físicos, constituindo eles um mundo causal autônomo. Portanto, se você esposou o eliminativismo, ou, se não isto, você está se movimentando além em direção ao dualismo que afirma a existência de um reino do mental em total isolamento causal com o mundo físico [...] Nossa conclusão, portanto, tem que ser esta: o materialismo não-reducionista não é um posicionamento estável. Há pressuposições de várias espécies que o empurram ou em direção ao um eliminativismo direto ou em direção de uma forma explícita de dualismo (Kim, 1999, p. 5).

Tal instabilidade, que é definida claramente por Kim como um dilema construtivo ${ }^{4}$ para o fisicismo não-reducionista contemporâneo, pode ser considerado, na visão que advogo aqui, como resultado de assunções relativas à concepção fisicista da substância, segundo a qual tudo o que permanece mediante a mudança ou subsiste é a matéria física, concepção esta que está pressuposta por muitos argumentos fisicistas. A meu ver, o

\footnotetext{
${ }^{4}$ Em correspondência pessoal com Gordon Globus, ele sugeriu que este argumento de Kim fosse descrito como um stalemate, posição no xadrez em que o empate se segue à impossibilidade de um dos lados conseguir mover suas peças. Porém, em correspondência com Kim, este esclareceu que o argumento tem a forma lógica de um dilema, um dilema construtivo.
} 
movimento correto para evitar a instabilidade do debate mente-corpo é em direção de uma forma mais forte de dualismo, à qual chamo dualismo elementar.

\section{2 - Os Argumentos de Superveniência Psicofisica Extraídos do Funcionalismo}

Nesta seção, como parte da justificativa para a escolha do dualismo elementar, pretendo discutir os argumentos de superveniência fundamentais em favor do fisicismo sobre a relação mente-corpo, argumentos que foram fundamentados em muitas premissas, entre as quais destacaria as premissas do funcionalismo na explicação das relações mentecorpo. Começo com uma consideração da definição da relação de superveniência. Posteriormente, introduzo uma tese de superveniência psicofísica fundamentada em definições, e então avalio criticamente o argumento de superveniência e suas premissas.

Para começar, é útil introduzir e capturar a intuição envolvida na noção de superveniência. Aristóteles explicou o significado de superveniência da forma seguinte: "O prazer completa a atividade não como o estado permanente correspondente faz pela sua

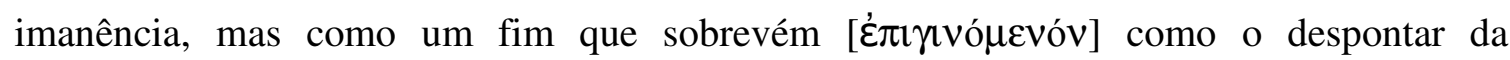
juventude faz naqueles que estão na flor de sua idade",5. Ou seja, na explicação de Aristóteles, o prazer é definido como sobreveniente às atividades prazerosas que defluem da juventude. O trecho seguinte esclarece mais a noção de superveniência:

5 Cf. Aristóteles, Ética a Nicômaco, 1174b31-33, citado em Heil (1992, p. 67) e em Hare (1984, nota 1), que aceitou a tradução do termo grego destacado. Em correspondência pessoal, tenho sabido que alguns intérpretes do grego jônico (Plato scholars) crêem ser inconveniente traduzir o termo grego sob o termo latino supervenire. Mas, no presente contexto, eu estou apenas introduzindo a noção de superveniência, sem entrar em detalhes ulteriores sobre a tradução do termo grego, detalhes dos quais se faria questão em outros ensaios em Filosofia Antiga. 
O termo "superveniência" deriva-se etimologicamente do latim "super", significando sobre, acima, adicional, e do verbo latino "venire", que significa vir. Nos contextos nãofilosóficos o verbo é utilizado primariamente de um modo temporal - tipicamente para significar "vindo" ou ocorrendo como uma coisa nova, adicional, inesperada. Em contextos filosóficos, é primariamente utilizado não-temporalmente para significar uma relação de determinação metafísica e/ou conceitual; aqui a etimologia parece ser quase metafórica espacialmente, a ideia sendo que algo superveniente vem sobre - está "fundamentado por" - aquilo ao qual supervém (Horgan, 1993, p. 555).

As relações de superveniência, que pressupõem a intuição sobre a dependência e sobre sua oposta, a relação de determinação, foram durante muito tempo consideradas como assunções para a formulação da interpretação fisicista do problema mente-corpo. Três questões têm sido cruciais para a discussão da superveniência e sua relação com as teorias da relação mente-corpo:

(Q1) Como definir e explicar a novidade envolvida modalmente na relação de superveniência especificada para defesa do fisicismo, dado que existem muitas variedades de relação de superveniência? ${ }^{6}$

(Q2) É adequada a formulação do problema mente-corpo como uma tese de superveniência? ${ }^{7}$

(Q3) Como explicar fisicamente as teses de superveniência via argumentos com vistas a evitar a redução psicofísica forte e satisfazer as condições para a proposta de uma ontologia materialista da mente? ${ }^{8}$

\footnotetext{
${ }^{6}$ Para comentários sobre a variedade prolífica de definições lógico-filosóficas das teses de superveniência no fisicismo contemporâneo, veja-se Kim (1993, ensaio 7) e Lewis (1986, p. 14).

${ }^{7}$ A formulação supervenientista do materialismo foi proposta pela primeira vez por Davidson (1970, 1985), por Horgan (1982) e depois por Kim (1993), que desenvolveu e refinou a formulação e solução supervenientista do problema mente-corpo. Alguns anos depois, houve desacordos sobre a adequação da relação de superveniência para enfocar a questão, ainda polêmica, de como formular o materialismo sobre as relações mente-corpo. Por exemplo, veja-se Horgan (1993), Hawthorne (2002) e Putnam (1999, parte II).
} 
No que concerne à primeira questão, da definição de superveniência, há muitas maneiras de classificar as relações de superveniência, propostas de modo a formular o fisicismo. Fundamentais para a relação de superveniência são (1) a propriedade de determinação, e sua inversa, (2) a propriedade de dependência (cf. Kim, 1993, pp. 54, 131 ff). Assim, no caso da variedade psicofísica da relação de superveniência, o fisicismo alega que existe uma dependência do mental em relação ao físico ou, inversamente, que existe uma determinação das propriedades, eventos, estados e processos mentais por aqueles físicos (corporais). A dependência e a determinação são definidas em cada teoria na qual a relação de superveniência fundamenta a formulação de diversas teses de superveniência psicofísica. Muitos filósofos analíticos ${ }^{9}$ propuseram as formas mais simples de dependência ou de determinação dos relata de propriedades.

Tais formas podem ser logicamente expressas como se segue. Sejam W e W' dois conjuntos de propriedades, propriedades sobrevenientes e propriedades de base, ou subvenientes, definidas para um único domínio (supomos domínio único por conveniência para a ontologia materialista da mente que nos interessa especificamente) ao qual pertence certo objeto. W supervém a W' se e somente se:

(i) W nada mais é do que $\mathrm{W}^{,}{ }^{10}$

\footnotetext{
${ }^{8}$ Davidson (1970, 1980 e 1985) foi o autor do artigo seminal sobre um argumento materialista e anti-reducionista em favor da tese de superveniência psicofísica. Explicarei o argumento de Davidson a seguir.

${ }^{9}$ Horgan (1982, p. 97), Hare (1984, p. 1), Kim (1993, ensaios 4 e 8, e 1998), Lewis (1986), Heil (1992), McLaughlin (1996), Drai (1999) e Jackson (1994).

${ }^{10}$ Armstrong (1989, p. 56), citado por Humphreys (1997, p. S338, nota 2). Esta é expressão da tese de identidade psicofísica, dos materialistas de identidade. Os domínios de propriedades W e W' referem-se ao mesmo objeto, num único domínio definido para a relação de superveniência. Por exemplo: W (a mente) supervém a W' (o sistema nervoso central) porque W é idêntico a W' (segundo os teóricos da identidade mente-cérebro, como Armstrong). Da perspectiva da teoria da identidade de Frege, trata-se de uma identidade singular.
} 
(ii) Não há uma mudança qualquer em $\mathrm{W}$ se não houver mudança física em $\mathrm{W}{ }^{\text {11 }}{ }^{11}$

(iii) Não há diferença em W (alguma propriedade) sem haver diferença em W' (outra propriedade) (Jackson, 1994).

(iv) Não há dois eventos semelhantes com relação aos seus aspectos físicos em W' mas diferindo em algum aspecto mental em W (Davidson, 1980, p. 214).

(v) Fixando o físico em W'é fixar tudo o mais em W (Kim, 1993, p. 155; Horgan, 1982, p. 32).

(vi) Nada em W é doutra forma se e somente se algo físico em W' é doutra forma (Haugeland, 1982, p. 97).

(vii) Não poderia haver o caso em que o mundo físico em W' é o mesmo e o mundo mental em W difira ou se altere (Haugeland, 1982, p. 97).

(viii) Propriedades-W supervêm às propriedades-W' se não houver situações possíveis que são idênticas com relação às propriedades-W' enquanto diferindo com relação às propriedades-W (Chalmers, 1996, p. 24).

(ix) Não há diferença de alguma espécie em W sem que haja diferença em outra espécie em W’ (Lewis, 1986, apud Horgan, 1993, p. 568).

(x) Objetos que são indiscerníveis com relação às propriedades de um tipo em W' (propriedades de base, subvenientes) são indiscerníveis com relação às propriedades doutro tipo em W (propriedades sobrevenientes) (Kim, 1993, p. 109).

\footnotetext{
${ }^{11}$ A mudança, comumente referida na tradição analítica como "Cambridge change", a la Russell, isto é, a percepção aparente de que um objeto apresente uma propriedade $p$ no instante te não apresenta tal propriedade no instante seguinte, a qual Leibniz chamava simplesmente de tempo ou sucedaneum, me parece ser um fundamento metafisicamente mais simples para definir a superveniência, mais simples do que outra formulação extraída das ciências especiais. Exemplos de formulações extraídas das ciências especiais seriam, por exemplo, as formulações de noções de superveniência em termos de pares ordenados, de covariança forte ou fraca, de indiscernibilidade ou similaridade através de mundos (como na definição de superveniência global) e de domínios múltiplos de objetos com propriedades.
} 
Em termos lógicos, as definições mais desenvolvidas de superveniência são as variedades graduadas de acordo com a força modal forte e fraca de tal relação. Tais definições lógicas são bem conhecidas, e são expressas nas formas seguintes ${ }^{\mathbf{1 2}}$. Sejam A e B propriedades que pertencem aos domínios W e W'. Seja também o domínio da relação de superveniência composto por objetos $x$ e $y$. Então:

$$
\begin{aligned}
& \forall \mathrm{A} \forall x(\mathrm{~A} x \rightarrow \exists \mathrm{B}(\mathrm{B} x \wedge \diamond \forall y(\mathrm{~B} y \rightarrow \mathrm{A} y))) \\
& \forall \mathrm{A} \forall x(\mathrm{~A} x \rightarrow \exists \mathrm{B}(\mathrm{B} x \wedge \quad \forall y(\mathrm{~B} y \rightarrow \mathrm{A} y)))
\end{aligned}
$$

são definições que podem ser interpretadas na linguagem natural da seguinte maneira. (1) Superveniência fraca: necessariamente, se algum objeto tem a propriedade A em W, então existe uma propriedade B em $\mathrm{W}^{\prime}$ tal que, o objeto tem B e, possivelmente, qualquer objeto que tem B tem A. (2) Superveniência forte: necessariamente, se algum objeto tem a propriedade $\mathrm{A}$ em $\mathrm{W}$, então existe uma propriedade $\mathrm{B}$ em $\mathrm{W}^{\prime}$ tal que o objeto que tem $\mathrm{B}$ e, necessariamente, qualquer objeto que tem B tem A.

Estas são definições analiticas ${ }^{13}$ para a relação de superveniência que têm sido propostas para capturar a intuição metafísica de dependência entre estados, propriedades,

\footnotetext{
${ }^{12}$ Cf. Horgan (1982, p.32; 1993, pp. 566-7), Heil (1992, p.70), Kim (1993, pp. 57-70, 140-2), Drai (1999, cap. 1) e Savellos \& Yalçin (1996, p. 3).

${ }^{13}$ Eu acrescento uma definição logicamente mais rigorosa da relação de superveniência a priori: seja L uma lógica na qual a classe de objetos está selecionada e $x$ seja um objeto de uma tal classe, $\varphi$ e $\psi$ dois predicados unários de um conjunto de predicados que são fechados sob operações booleanas que podem gerar infinitamente muitas propriedades a partir das operações booleanas. Dados modelos fisicistas ou a priori de interpretação dos operadores modais, há duas variedades definíveis de superveniência a seguir: (1) $\psi$ sobrevém fracamente a $\varphi$ se, e somente se, necessariamente, para todo $x$, se $x$ tem $\varphi$, então possivelmente $\mathrm{x}$ tem $\psi ;(2) \psi$ sobrevém fortemente a $\varphi$, se e somente se, necessariamente, para todo $x$, se $x$ tem $\varphi$, então necessariamente $x$ tem $\psi$. Semelhantemente às definições explicadas acima, definições mais completas podem ser formuladas a partir destas mais simples.
} 
processos, etc., hierarquicamente organizados ou não, ou de sua inversa, a determinação entre propriedades e processos. Tais definições são pressupostas nas variedades mais desenvolvidas de superveniência, para argumentar em favor do fisicismo, especificamente concernente à conexão entre os níveis da mente e dos corpos físicos. Com vistas a avaliar o fisicismo interpretado como tese de superveniência, eu interpretarei a superveniência simplesmente como uma tese metafísica sobre a mudança, compreendida como mudança de propriedades mentais e físicas. Colocando de outra forma, não ocorre nenhuma mudança com respeito a A em W sem que ocorra uma mudança com respeito a B em W' (Drai, 1999, p. 2), definição a que chamarei de "superveniência da mudança" (Cambridge change supervenience).

Com relação à segunda questão, sobre se a superveniência é adequada para formular o problema mente corpo, a superveniência de mudança é considerada como uma relação metafísica fundamental para interpretar de modo físico o problema mente-corpo (Kim, 1998, p. 14), que se torna definível por meio de relações de superveniência. Aqui, há uma questão a ser considerada: a simetria ou a assimetria da relação de superveniência, e sua relevância para a definição da ontologia material do relatum mental. Com vistas a formular a tese fisicista sobre o problema mente-corpo, alguns filósofos ${ }^{14} \operatorname{argumentaram~que~a~}$ relação é assimétrica, ou seja, o mental depende de ou é determinado pelo físico, mas não vice-versa, e esta determinação “de mão única” (not a two-way street; cf. Miller, 1990) tornaria a superveniência adequada para alegar que a matéria física seja prioritária em

\footnotetext{
${ }^{14} \mathrm{Nem}$ todos concordam sobre este ponto, alguns alegam que a superveniência seja uma relação simétrica, isto é, se A sobrevém a B, B sobrevém a A. Isto pode ocorrer se for provado que A sobrevém a B, como no caso da superveniência psicofísica de A sobre B e se for também provado que há também causação mental de A sobre B. Sobre a questão da simetria, veja-se, por exemplo, Miller (1990) e Kim (1998, p. 11).
} 
relação ao mental e, portanto, o físico seria a base subveniente a partir da qual o mental e tudo o mais sobrevém (isto é, superveniência de tudo sobre o "físico", ou superveniência cósmica).

A terceira questão, mencionada anteriormente, é a questão central, situável consensualmente, sobre como explicar que o mental sobrevém à famigerada "base física" ou ao "correlato corporal" ou, alternativamente, como é possível que não haja mudança da mente sem que haja mudança na matéria física, ou como o corpo físico "determina" as mudanças mentais, ou ainda como estas "dependem" do corpo físico. Focalizarei esta questão no que se segue.

Os argumentos fundamentais para a explicação não-reducionista da superveniência psicofísica sobre fundamentos a posteriori foram formulados a partir de premissas extraídas de diversas teorias, dentre as quais podemos mencionar o monismo anômalo (Davidson, 1970, 1985, pp. 209-15), a completude da física ${ }^{15}$, o realizacionismo múltiplo ${ }^{16}$ e múltipla especificação causal (Lewis, 1966; Kim, 1998), como variedades do funcionalismo e da fenomenologia funcional não-reducionista ${ }^{17}$. Para o presente propósito

\footnotetext{
${ }^{15}$ Horgan $(1982,1983)$, onde ele define a noção de superveniência como hermenêutica cósmica, isto é, como interpretação de todas as verdades acerca do universo com base nas inferências lógicas deduzidas a partir das verdades aceitas na linguagem da física. E Papineau (2001), que explicou a origem do fisicismo como tese principal do argumento para o fisicismo como tese sobre a completude da física. Jackson (1994) argumenta em favor de uma tese de superveniência psicofísica como uma tese de implicação lógica no exemplo de sua defesa da análise conceitual.

${ }^{16}$ Putnam (1975), que propôs que o funcionalismo é compatível com a tese de identidade fraca (token identity thesis), e Kim (1982, 1993 e 1998), que assumiu premissas dos argumentos funcionalistas de Putnam como passo fundamental para defesa de seu argumento de superveniência.

${ }^{17}$ Chalmers (1996, parte II, cap. 7.2). O argumento de Chalmers para o dualismo a partir do funcionalismo não-reducionista parece, segundo penso, divergir sutilmente das posições fisicistas que pressupõem a tese de primazia. Mas, por outro lado, Chalmers parece estar comprometido com o desideratum de explicação da tese de superveniência, que está fundada na tese de primazia em sua formulação fisicista. Por esta razão, duvido que o universo físico seja ontologicamente prioritário para ele.
} 
de elaboração da justificação das premissas do dualismo elementar, descreverei os argumentos sucintamente como se segue.

Primeiramente, temos que considerar o argumento para a tese de identidade psicofísica fraca a partir do monismo anômalo, que nos interessa aqui pelo uso que faz da tese de primazia do físico. A ideia básica deste argumento, que foi seminal na introdução de argumentos para teses de superveniência sobre o problema mente-corpo, é a reconciliação de três princípios dispostos numa tríade inconsistente:

(A1) Princípio de Interação Causal: Eventos mentais causam eventos físicos.

(A2) Caráter Nomológico da Causalidade: Quando dois eventos estão numa relação causal, uma lei determinística estrita fundamenta tal relação.

(A3) Anomalismo do Mental: Não há leis estritas determinísticas com base nas quais os eventos mentais possam ser preditos ou explicados.

Considerando a validade das teses a que nos referimos acima, afirma-se, no argumento de Davidson, que elas não podem ser todas verdadeiras simultaneamente; tem-se uma tríade inconsistente. Porque se assumimos que o primeiro princípio é verdadeiro, devese inferir que seja verdadeiro que haja relação psicofísica de modo que os eventos mentais causem os eventos físicos. Se se assume que o segundo princípio seja verdadeiro, devemos inferir que deva haver uma lei estrita ("estrita" no sentido de um universal lógico) e determinística ("determinística" significando que haja univocidade na relação causal, ou seja, para todo efeito físico há uma, e somente uma, causa), com base na qual se pode explicar e predizer qualquer evento mental. Se os três princípios são assumidos como 
verdadeiros, então há uma contradição, pois segue-se dos dois primeiros que há leis psicofísicas estritas e determinísticas, o que contraria o terceiro princípio.

A reconciliação dos princípios do argumento exposto depende da maneira de descrever os eventos físicos fundamentados por leis. Uma solução é que não haveria leis psicofísicas, ${ }^{18}$ mas somente leis físicas ligando eventos, e tais eventos são somente físicos. Segundo esta linha de argumento, pode-se inferir que os eventos mentais são idênticos aos eventos físicos (a tese de identidade psicofísica) e, portanto, não há mudança mental sem que haja mudança física, uma conclusão que estabelece a tese de superveniência (cf. Davidson, 1980, p. 209).

Em segundo lugar, consideremos o fisicismo em termos da tese de completude da física. Consideremos aqui brevemente duas formulações da tese e dois argumentos relacionados. A tese de completude é uma premissa central do argumento para o fisicismo, e ela pode ser afirmada a partir de fontes a priori ou a posteriori.

A tese de completude a priori é conhecida como hermenêutica cósmica (Horgan, 1982) ou interpretação completa e física das verdades, interpretação que é precisamente representada pela alegação de que para toda verdade acerca do universo, existe uma correspondente verdade física, expressa em linguagem da física; ou seja, qualquer verdade sobre o universo segue necessariamente de uma sentença física verdadeira. ${ }^{19}$ A necessidade lógica é interpretada simpliciter para todo mundo possível, uma interpretação chamada de "tese de entrada por implicação" (entry by entailment) (Jackson, 1994, p. 27). Assim,

\footnotetext{
${ }^{18}$ Para uma apreciação crítica do argumento de Davidson, que se relaciona com tese de identidade defendida no argumento davidsoniano, ver Drai (1999, p. 86-96). Para uma literatura completa e atualizada sobre defesas e críticas do monismo anômalo, ver Chalmers www.consc.net/mindpapers/4.1d.

${ }^{19}$ Cf. Byrne (1999, p. 347), para uma avaliação crítica do argumento de Horgan para a completude a priori da física.
} 
haveria implicações de verdades sobre o universo mental a partir das verdades sobre o universo físico. $\mathrm{O}$ argumento extraído da tese de completude a priori funciona asserindo-se que o mental ou o psicológico supervém ao físico ou fisiológico, se a verdade acerca do mental é implicada, ou logicamente implicada, pela verdade acerca do físico.

A tese de completude a posteriori é asserida a partir da interpretação naturalísticafilosófica da física. A metafísica da completude da física assevera que todos os efeitos físicos são completamente determinados pelas leis físicas e pela série causal ou histórica. Esta interpretação é feita com base nas premissas inspiradas em fundamentos empíricos, fundamentos que residem basicamente nas leis de conservação, e na sua relação com a questão da inclusão de forças mentais em meio ao mundo físico (Papineau, 2001). Como colocado por alguns autores, o argumento causal para a superveniência do mental, que pressupõe a tese de completude da física, é expresso pelas teses seguintes (Papineau, 2001):

(B1) Completude da Física: Todos os efeitos físicos são completamente determinados por lei e por uma história causal prévia.

(B2) Causação Psicofísica: Todas as ocorrências mentais têm causas físicas.

(B3) Não-sobredeterminação: Os efeitos físicos de causas mentais não são sobredeterminados $^{20}$, ou seja, não pode haver mais de uma causa numericamente distinta para um dado efeito físico.

(B4) Identidade Psicofísica: As causas mentais são ontologicamente idênticas às causas físicas, donde segue-se a fortiori:

\footnotetext{
${ }^{20}$ A forma concisa do argumento é devida a Papineau (2003).
} 
(B5) Superveniência Psicofísica: Não há mudança natural causal no mental a menos que haja uma mudança causal do físico ${ }^{21}$.

A primeira premissa assere que a física é ideal e causalmente completa. Se se questiona o significado do termo "físico", então existe uma forma de questionar tal premissa, pois a teoria física contemporânea não é consensualmente considerada completa (assumindo-se que o termo "completude" refira-se também à completude da física atual) (cf. Papineau, 2003).

Agora, temos que considerar a doutrina do funcionalismo reducionista, seja ela afirmada como funcionalismo de máquina ou como múltipla especificação causal. A teoria funcional é fundamentada de duas formas. Ou sobre os estados computacionais ou sobre as relações causais definidas na física clássica. Na primeira, o funcionalismo é fundamentado na tese de realização múltipla ou sobre a múltipla especificação causal de propriedades de segunda-ordem do corpo físico, tal como se argumenta em favor da tese fraca de identidade psicofísica. Portanto, segue-se do funcionalismo que não há mudança mental sem mudança física, uma conclusão que declara nominalmente a tese de superveniência psicofísica. Existem as formas reducionistas de funcionalismo, com a redução significando identidade da experiência subjetiva fenomênica, ou qualia, com as mudanças nas propriedades físicas. Como consenso, sabe-se que duas objeções a estas principais variedades de funcionalismo foram levantadas. A objeção crucial é que os estados, eventos, propriedades e eventos, etc, não são idênticos totalmente aos estados, eventos e propriedades, etc., funcionais de

\footnotetext{
${ }^{21} \mathrm{Eu}$ acrescentei a tese de superveniência no argumento, que, sendo mais fraca que as anteriores, segue-se a fortiori. A forma concisa do argumento é dada por Papineau (2003).
} 
segunda ordem ${ }^{22}$ em muitos casos, principalmente no caso crucial das experiências fenomênicas ou qualia. Além disso, existe outra objeção que diz que o funcionalismo pode conduzir, tal como discutirei na seção I.4, ao argumento de exclusão causal ou "argumento mestre" (master argument: cf. Kim, 1998; Block, 1990; Nasrin, 2000).

Além do funcionalismo reducionista, tem-se que considerar outra teoria digna de nota, a interpretação funcionalista não-reducionista (Chalmers, 1996, p. 275) do problema mente-corpo, que foi proposta para preservar a teoria funcionalista e incluir a mente consciente, que estaria excluída da teoria funcionalista reducionista de segunda ordem. O dualismo naturalista de Chalmers argumenta que a fenomenologia é salva pela combinação da ontologia da base física ou neurofisiológica do corpo com um dualismo de propriedades, sendo este dualismo constituído de propriedades fenomênicas ou protofenomênicas, juntamente com as propriedades físicas ou neurofisiológicas. Isto dá ao mental enquanto consciência uma importância ontológica fundamental, e o funcionalismo (na variedade da múltipla especificação causal) é preservado como uma premissa do argumento do dualismo naturalista para a explicação da superveniência psicofísica.

De acordo com o dualismo naturalista, com referência à critica contemporânea do fisicismo, não é necessário pressupor a primazia do físico na explicação fisicista da origem da mente consciente (Chalmers, 1996, p. 298). O dualismo naturalista argumenta,

${ }^{22}$ Cf. Kim (1998, pp. 19-23). Uma propriedade de segunda ordem é a propriedade de uma propriedade (de primeira ordem) de um certo objeto. Neste caso, quantifica-se sobre as propriedades do objeto, que são de primeira ordem. Aplicando-se esta noção ao caso da relação mente-corpo, na teoria funcionalista ou da realização física da mente, se diz que as propriedades mentais são propriedades de propriedades físicas do corpo e que, dado que as propriedades mentais são propriedades funcionais do organismo como um todo, as propriedades funcionais são propriedades de segunda-ordem do físico. Como bem definiu Kim (1998, p. 20): "F é uma propriedade de segunda-ordem sobre o conjunto $\mathbf{B}$ de base (ou de primeira ordem) de propriedades se, e somente se, F é a propriedade de ter alguma propriedade $\mathrm{P}$ em $\mathbf{B}$ tal que $\mathrm{D}(\mathrm{P})$, onde $\mathrm{D}$ especifica uma condição dos membros de B." 
fundamentado em alguns princípios funcionalistas, em favor da tese de que a mente consciente supervém naturalmente sobre o físico (e, conjuntamente, sobre o fenomênico), negando, portanto, a tese de primazia pressuposta pelo funcionalismo reducionista no fisicismo mínimo (minimal physicalism) ${ }^{23}$. Desde que a tese de primazia não seja pressuposta necessariamente pelo dualismo naturalista, eu penso que esta teoria concorda, tanto concisa quanto positivamente em muitos pontos, com o dualismo elementar (pela admissão da importância ontológica da mente consciente). Este dualismo naturalista concorda, outrossim, tal como alguns argumentaram ${ }^{24}$, com o protopanpsiquismo, uma doutrina que atribui forte importância ontológica ao mental em meio ao universo físico. Para propósitos estratégicos, eu não relacionarei aqui tal teoria com minha proposta substancialista ou monadista a ser defendida neste ensaio.

A tese de primazia tem sido amplamente pressuposta em muitos argumentos ${ }^{25}$ e as definições de superveniência, bem como os argumentos fundamentais correlatos, têm expressado a tese de primazia na forma de uma tese de superveniência. A tese de primazia é uma das teses mais notáveis do fisicismo. As teses do fisicismo são expressáveis como se segue:

(C1) Ontologia Física: Tudo que existe são partes de matéria física e seus agregados com suas somas mereológicas e fusões (irrestritamente compostas) e, portanto,

\footnotetext{
${ }^{23}$ Chalmers (1996, seção 2.5 da parte I, e seção 7.1). A conjunção do fenomênico com o físico, como uma base subveniente a partir da qual a consciência supervém, foi sugerida por Byrne (1997), na avaliação do argumento em favor da hermenêutica cósmica.

${ }^{24}$ Cf. Chalmers (1996, pp. 297 ff), Seager (1995), MacLennan (1996) e Nagel (1986, cap. III, seções 1 a 6 ).

${ }^{25}$ Cf. Kim (1982, 2000), Horgan (1982), Haugeland (1982) e Jackson (1994).
} 
a matéria física é fundamental para explicar tudo que existe, incluindo tanto a mente consciente quanto a mente causativa.

(C2) Dualismo de Propriedades: Quando os sistemas físicos alcançam certo nível de organização em termos de complexidade, eles exibem propriedades nãofísicas.

(C3) Superveniência Psicofísica: Propriedades não físicas dos objetos e sistemas supervêm às suas propriedades físicas, isto é, não há mudança no mental sem que haja mudança no físico (Kim, 2000).

Neste ponto, dois argumentos de superveniência ${ }^{26}$ se seguem das noções de superveniência e da principal tese do fisicismo. A estrutura de tais argumentos se resume no seguinte:

(D1) Pressupõe-se que M é idêntico ao estado funcional S de um organismo com a estrutura relevante que especifica $\mathrm{M}$; e

(D2) A classe P realiza, ou especifica causalmente, em uma infinidade de formas atuais, os realizadores (realizers) $\mathrm{M}$ em um dado tempo; portanto

(D3) Segue-se a tese de superveniência psicofísica, em outras palavras, M supervém a $\mathrm{P}$, ambos no mesmo tempo, ou dito doutra forma, não pode haver mudança no mental sem que haja mudança física (na classe de eventos P).

\footnotetext{
${ }^{26}$ Cf. Kim (1993, pp. 191-2) e Kim (1998, p. 23). O primeiro argumenta a partir do funcionalismo computacional, ao passo que, o segundo, a partir do funcionalismo de múltipla especificação.
} 
Assim, a múltipla realização explicaria a superveniência do mental e constituiria uma explicação das relações mente-corpo (cf. Kim, 1998, p. 23).

Acredita-se, consensualmente, como resultado do debate em torno da superveniência, que algumas dificuldades dos argumentos funcionalistas de superveniência pareceram se reduzir a alguns pontos dignos de nota: primeiramente, o funcionalismo não descreve a fenomenologia da mente (esta parece ser uma alegação que prevalece entre os filósofos ${ }^{27}$ ); segundo, alguns autores argumentam que as propriedades funcionais de segunda-ordem levariam ao epifenomenalismo (o que é equivalente a dizer que o funcionalismo não inclui causalmente os estados qualitativos da mente); terceiro, a noção de matéria física, que parece ser claramente clássica (baroque picture), como pressuposto exclui causalmente a mentalidade. Em quarto, ademais, uma objeção à adequação da doutrina da superveniência para a questão da formulação do fisicismo afirma que a relação de superveniência não é adequada para formular o fisicismo não-reducionista ${ }^{28}$. Em quinto, tem-se objetado que a própria relação de superveniência psicofísica necessita de explicação ${ }^{29}$.

Em virtude dessas dificuldades, parece-nos que as relações de superveniência não conseguem sustentar a primazia ontológica do universo físico sobre o mental, com relação a alguns aspectos das propriedades naturais, sejam elas mentais ou físicas. Em face dessas dificuldades muito debatidas, alguns filósofos sugeriram, como é bem sabido, que as

\footnotetext{
${ }^{27}$ Levine (1993), Horgan (1993, nota 23, p. 580) e Chalmers (1996).

${ }^{28}$ Cf. Hogan (1993, p. 555), Kim (1998) e Gillett (2002, p. 92).

${ }^{29}$ Os filósofos fisicistas aceitam a ideia de que a relação de superveniência expressa, no contexto do fisicismo contemporâneo, relação mente-corpo com vistas a posicionar os argumentos explicativos da superveniência psicofísica. Cf. Horgan (1993, p. 556), Kim (1993, p. 156), Kim (1998, p. 13) e Heil (1992, p. 65).
} 
dificuldades implicadas pela redução pressuposta no enfoque de superveniência poderiam ser evitadas definindo-se o fisicismo em termos de emergentismo, sendo o emergentismo entendido aqui como não-superveniente ${ }^{30}$. Assim, é necessário considerar detalhadamente a classe de argumentos extraídos a partir da doutrina emergentista da mente.

\section{3 - Argumentos Emergentistas das Ciências Especiais}

Continuando com a justificativa para a escolha do dualismo elementar, eu gostaria de abordar as propostas e dificuldades dos enfoques emergentistas do problema mentecorpo. Tal como foi feito com relação à teoria da superveniência, definamos a noção de emergência, as teses de emergência e, conseqüentemente, os argumentos emergentistas relevantes para explicação das relações mente-corpo.

A par da formulação em termos da relação de superveniência, o problema mentecorpo tem sido, conforme depreendemos do debate recente, formulado de acordo com a tese emergentista não-supervenientista. Debateu-se, no curso da discussão, que a relação de superveniência não seria a mais adequada para a formulação do materialismo, em face das dificuldades mencionadas.

Tal como no caso das relações de superveniência, a relação de emergência tem uma vasta gama de definições a partir das quais teses são formuladas e argumentos são propostos para explicar a relação psicofísica.

${ }^{30}$ Em relação à questão da formulação do emergentismo, alguns autores consideram a relação de emergência compatível com a relação de superveniência, ao passo que outros não. Para compatibilidade, cf. Kim (2005) e Pessoa (2010). Para incompatibilidade, cf. Humphreys (1997). 
Argumenta-se a favor da adequação da relação de emergência não-superveniente com base em, principalmente, duas razões. Primeiro, para evitar a redução pressuposta na, ou implicada pela, metafísica das propriedades supervenientes (como conseqüência dos argumentos do funcionalismo), em meio às quais estão as propriedades mentais. Segundo, para considerar a persuasão dos argumentos que mostram que o mental não é funcionalizável em alguns casos, aos quais me referirei a seguir.

A noção de emergência é capturada pela ideia intuitiva de uma novidade inexplicável, tais como a mente surgindo a partir das partes próprias da matéria. Muitos emergentistas concordaram com a tese de que a novidade é o aspecto da noção de emergência que parece ser essencial. Diferentemente da superveniência, na qual as operações booleanas, combinando as propriedades de base, podem fixar, e em conseqüência explicar funcionalmente (no caso da superveniência forte, de tipo funcionalista kimiano, que interessa para a explicação das relações mente-corpo) as propriedades supervenientes, a emergência não-superveniente não é de forma alguma explicável ou predizível ou mesmo fixável pelas propriedades de base: as propriedades emergentes são completamente novas. No caso da superveniência, pode existir, via argumento, uma explicação de acordo com as descrições funcionais, sejam elas maquinais ou causais. No caso da emergência, o mental seria completamente novo, inexplicável e imprevisível a partir da classe basal de propriedades ou condições. Argumentativamente, a teoria da evolução seria uma referência para explicar tais novidades. Diretamente relacionada à questão de como definir as propriedades emergentes, existe, como pressuposição, a questão de se a emergência seria uma tese epistemológica ou ontológica. Alguns autores argumentam em favor da tese de que a emergência seja epistemológica (Nagel, 1961; Teller, 1992; Humphreys, 1997; Wimsatt, 1997), enquanto outros em favor da emergência ontológica (Stephan, 1992, 1999; 
Pihlström, 2002). Defendendo uma ontologia substancial monádica entre a mente e a matéria física, eu considerarei brevemente a emergência na conclusão e tomarei a posição de que as propriedades, processos, estados e eventos emergem como novas entidades relacionadas a novas percepções monádicas.

Qual a característica definidora das propriedades emergentes? Há diferentes propostas, constituindo diferentes variedades de emergência, sendo que as mais importantes são (Stephan, 1996, 1999; Kim, 1999, 2000; Pihlström, 2002): emergência enquanto novidade (Teller, 1992, pp. 139-40; Stephan, 1992, 1999), não-aditividade (Nagel, 1961), imprevisibilidade absoluta e relativa (Stephan, 1992, 1999, referindo-se à noção de Popper de emergência absoluta).

No sentido da novidade, existem muitos aspectos considerados pelos emergentistas. Por exemplo, afirma-se que os emergentes introduzem novos aspectos (de espécie mental, sejam eles entidades ou propriedades) que são instanciadas pela primeira vez. A emergência pode ser vista como gerando estados mentais ligados holisticamente ${ }^{31}$. A relação temporal entre a base e o emergente define duas espécies de emergência: sincrônica e diacrônica ${ }^{32}$. No primeiro caso, diacrônico e atemporal, o emergente surge a partir de uma condição de base dada no mesmo instante. No segundo caso, o diacrônico, temporal, o emergente se origina num tempo que é posterior ao tempo de surgimento de sua base correspondente, por exemplo no curso da evolução biológica ${ }^{33}$.

\footnotetext{
${ }^{31}$ Esta visão holística da emergência do mental é defendida por Davidson (1999).

32 Cf. Nagel (1961, pp. 266-80), também a terminologia introduzida por Stephan (1999, p.51) e, para uma explicação, veja Pihlström (2002).

33 Cf. Nagel (1961) para uma definição de evolução emergente inspirada nos primeiros emergentistas.
} 
A não-aditividade é outra fonte clássica da noção de emergência. $\mathrm{Na}$ física ${ }^{34}$, ela se consistiu num contra-exemplo ao princípio físico de aditividade, ou seja, à situação em que um efeito é a soma ponderada das causas, como ocorre na adição vetorial de duas forças impulsivas (que atuam em um intervalo de tempo curtíssimo). Por exemplo, o efeito de duas tacadas feitas ao mesmo tempo em uma bola de bilhar (com tacos diferentes) resulta num efeito que é a soma dos efeitos de cada tacada individual. Os emergentistas apontaram contra-exemplos a esta situação simples da mecânica clássica. Um exemplo dado por John Stuart Mill é o da combinação química de dois líquidos, um transparente e outro azul. Um processo aditivo levaria a uma solução com uma cor azul clara, mas às vezes pode surgir um composto vermelho, um exemplo de processo não-aditivo, ou não-linear. Mill ([1843] 1979, cap. V) cunhou o termo "homopático" para a adição simples, e "heteropático" para a situação em que emerge uma nova propriedade.

Nos debates, deve-se também dar relevância à emergência na medida em que esta tem a ver com os aspectos epistemológicos da explicação, isto é, a dedutibilidade e a previsibilidade dos emergentes. A não-dedutibilidade e a imprevisibilidade são consideradas de diferentes formas: como novidade dos emergentes, como o laço heteronômico entre as condições basais e os emergentes físicos (Kim, 1999, p. 3; Humphreys, 1997, p. S342; e Stephan, 1992, pp. 28-9), como irredutibilidade do nível emergente ao nível basal (Kim (1992, 1999, 2000), e como a não-dedutibilidade e imprevisibilidade teóricas dos emergentes (Broad, 1925, p. 61; Nagel, 1961, pp. 336 ff; Kim, 1999, pp. 13 ff; Stephan, 1992, pp. 28-9; 1999, p. 51).

\footnotetext{
${ }^{34}$ Tal como é aludido por Nagel (1961, p. 241), Kim (1999, p. 1) e Stephan (1992, p. 28). O precursor foi Stuart Mill e existe um argumento para a não-aditividade vetorial em Russell. Tal argumento trata da não-redutibilidade da resultante vetorial aos seus componentes, argumento do qual Nagel discordou.
} 
Como no caso do fisicismo formulado de acordo com a relação lógica de superveniência, a posição emergentista é comumente formulada com base nas noções de emergência referidas acima, expressáveis de acordo com as seguintes teses:

(E1) Ontologia Física Fundamental: Existem entidades e propriedades básicas não emergentes e estas são relativas a entidades materiais que são propriedades físicas fundamentais.

(E2) Emergência de Propriedades: Quando os agregados de entidades básicas alcançam certo nível de complexidade estrutural (relacional), propriedades genuinamente novas emergem para caracterizar tais agregados estruturados. Ademais, estas propriedades emergem somente quando as condições basais apropriadas estão presentes.

(E3) Fisicismo Não-Reducionista: As propriedades emergentes são novas no sentido de que elas não são redutivamente explicáveis em termos das condições a partir das quais elas emergem (Kim, 1992).

Como no caso da doutrina da superveniência, um argumento foi proposto pelo emergentismo, cuja tese principal segue-se das teses descritas acima. Para o propósito da defesa do monadismo, salientamos que as premissas para o argumento em favor do emergentismo foram extraídas de três fontes relevantes inter-relacionadas: teoria evolutiva, que é a fonte principal de premissas emergentistas, e duas doutrinas relevantes, quais sejam, a síntese física e o múltiplo realizacionismo, ambos invocados para explicar 
alternativamente como os emergentes surgem. A primeira fonte é a teoria que se resume na seguinte passagem:

Eu falo de eventos em um dado nível qualquer na pirâmide da evolução emergente como 'envolvendo' os eventos concorrentes nos níveis inferiores. Algo que emerge, em qualquer nível dado, dá suporte a uma instância [affords an instance] do que considero ser uma nova espécie de relação da qual não há instâncias nos níveis inferiores. $\mathrm{O}$ mundo foi sucessivamente enriquecido através do advento de relações conscientes e vitais [...] Sendo elas de alguma forma dadas, devem ser consideradas tal como as encontramos. Mas quando alguma nova espécie de relação é superveniente (digamos no nível da vida) a forma na qual os eventos físicos que estão envolvidos percorrem seu curso é diferente em virtude da sua presença - diferente da situação em que estaria se a vida estivesse ausente (Lloyd Morgan, 1923, apud Horgan, 1993, p. 558).

A noção de curso evolutivo está na base das teses que são relacionadas com a noção de complexidade estrutural do organismo. Aqui eu gostaria de considerar as teorias que procuram explicar como propriedades, estados, eventos e entidades emergem. Estas teorias podem ser, por exemplo, expressas no funcionalismo, no realizacionismo múltiplo, ou na teoria quântica, teorias que podem ser combinadas com a tese de dualismo de propriedades. A questão crucial para o emergentista é explicar como as propriedades emergentes (mentais) M surgem a partir das condições basais (físicas) P.

Podemos considerar três maneiras de formular a relação M-P da emergência. (1) Emergência como realizabilidade múltipla de propriedades de alto nível em meio às propriedades basais físicas, e sua inversa, a plasticidade construtiva ${ }^{35}$ do emergente em relação a suas condições basais, isto é, M é realizável, talvez em uma infinidade de formas, em meio aos Ps, e esta teoria assume que uma propriedade emergente, uma entidade, um

\footnotetext{
${ }^{35} \mathrm{O}$ leitor pode achar estranho considerar a relação inversa da realizabilidade múltipla, isto é, da plasticidade construtiva. Cf. para uma explicação posterior, Endicott (1994).
} 
estado ou um evento seja funcionalizável, isto é, identificável com um estado funcional ${ }^{36}$;

(2) Emergência como um fenômeno físico chamado fusão, e seu fenômeno inverso, a

fissão, fenômenos que conectam níveis da natureza que poderiam ligar o nível mental com

o físico ${ }^{37}$. (3) Emergência como herança de potências causativas funcionais ${ }^{38}$, também

fundamentada no princípio de herança, que afirma que a potência causal do realizador é herdado pela propriedade a ser realizada ${ }^{39}$.

Mesmo com a proposta promissora de uma concepção do mental fornecida por tais doutrinas emergentistas, concepção que parece capturar a intuição do não-reducionismo

${ }^{36}$ Cf. Kim (1999, p. 10), no qual Kim argumenta a partir da identificação com relações causais/nômicas entre as propriedades mentais e físicas, sendo as últimas chamadas de bases de redução física. A definição de propriedade funcionalizável é dada por meio de três passos, dos quais salientamos o primeiro passo, por referir-se à propriedade funcionalizável:

"Seja $\mathbf{B}$ o domínio de propriedades (também fenômenos, fatos, etc, se você desejar) servindo como base de redução - para nós, este contém as condições basais para nossas propriedades emergentes. A redução da propriedade $E$ a $\mathbf{B}$ envolve três passos.

Passo 1: $E$ deve ser funcionalizada - isto é, $E$ deve ser interpretada, ou reinterpretada, como uma propriedade definida pelas suas relações causais/nômicas com outras propriedades, especificamente, propriedades na base de redução $\mathbf{B}$.

Nós podemos pensar em uma definição funcional de $E$ sobre o domínio $\mathbf{B}$ como tipicamente tendo a forma seguinte (simplificada):

Ter $E=_{\text {def. }}$ Ter alguma propriedade $P$ em $\mathbf{B}$ tal que (i) $\mathrm{C}_{1}, \ldots, \mathrm{C}_{\mathrm{n}}$ causa a instanciação de $P$, e (ii) $P$ causa a instanciação de $\mathrm{F}_{1}, \ldots, \mathrm{F}_{\mathrm{m}} . "$ (Kim, 1999, pp. 10-11).

Ou seja, Kim está se referindo a uma série causal ligando as propriedades $\mathrm{C}$ com as propriedades $\mathrm{F}$ por meio das propriedades $P$.

${ }^{37}$ Cf. Humphreys (1999b, pp. 9-10) para a definição de uma fusão mereológica física (não meramente lógica) de propriedades e entidades. Tal como ele define fusão como uma operação física real na natureza pelo símbolo de síntese física (.*.) de tal modo que no nível $\mathrm{L}$ na natureza existem propriedades $\mathrm{P}$ dos objetos, digamos, $x$ e $y$, tais que em um dado instante $t$ ocorre $\mathrm{o}$ seguinte: $\left(\mathrm{P}^{\mathrm{i}}(x)(t) * \mathrm{P}^{\mathrm{i}}(y)(t)\right)=\left(\mathrm{Pi}^{*} \mathrm{P}^{-\mathrm{i}}\right)((x+y))(t)=\mathrm{P}^{, \mathrm{i}+1}(x+y)(t)$, sendo que a segunda parte da igualdade expressa uma propriedade/objeto emergente nova e a esquerda sua propriedades basais.

${ }^{38}$ A doutrina das propriedades como "potências causativas" foi elaborada por Shoemaker (1980).

${ }^{39}$ Cf. Gillett (2002, pp. 94-6), onde lemos: "A instância da propriedade/relação $(s) \mathrm{F}_{1}, \ldots, \mathrm{F}_{\mathrm{n}}$ realiza uma instância da propriedade $\mathrm{G}$, num indivíduo $s$, se, e somente se, $s$ tem potências que são individuações de uma instância de $\mathrm{G}$ em virtude das potências concedidas por $\mathrm{F}_{1}, \ldots, \mathrm{F}_{\mathrm{n}}$ a $s$ ou pelo constituintes de $s$, mas não vice-versa." 
necessário para argumentar em favor da tese do fisicismo mínimo, os críticos do emergentismo salientam que existe ainda uma dificuldade crucial, a instabilidade do emergentismo fisicista, que é expresso pelo dilema construtivo de Kim (que vimos na seção I.1): "Eu argumentei em outro lugar contra o materialismo não-reducionista alegando que esta casa na metade do caminho é uma posição inerentemente instável e que ela ameaça colapsar ou em reducionismo ou numa forma mais séria de dualismo" (Kim, 1999, p. 5).

O dilema crucial da posição emergentista é concisamente explicado abaixo:

A dificuldade básica que o emergentismo enfrenta é uma que Kim formula como geralmente apavorando as teorias [...] que querem obter tanto irredutibilidade quanto dependência: se a relação entre o mental e os níveis físicos de propriedade é "fraca o suficiente" para ser não redutiva, ela tende a ser muito fraca para servir como uma relação de dependência; inversamente, quando a relação é forte o suficiente para nos dar dependência, ela tende a ser muito forte - forte o suficiente para implicar redutibilidade. ${ }^{40}$

Esta dificuldade crucial permanece mesmo quando um argumento é proposto satisfazendo a condição (seja esta a realizabilidade múltipla, a plasticidade construtiva, a síntese física por fusão, ou a doutrina causal da potência de propriedades, às quais nos referimos) exigida para emergência do mental. Isso porque os argumentos discutidos acabam por reduzir ontologicamente as propriedades de alto nível às basais, o que é contrário ao desideratum do fisicismo não-reducionista. A instabilidade faz o emergentismo fisicista ser uma posição difícil de sustentar com relação à solução do problema mentecorpo. E, por outro lado, no que se refere ao problema da relação mente-para-o-físico, a redutibilidade do mental à materia faz com que a mente seja causalmente inerte, tal como se

\footnotetext{
${ }^{40}$ Kim (1998, p. 140), apud Pihlström (2002). Esta dificuldade básica apontada por Kim e Pihlström a nós parecer ser crucial, com a qual muitos fisicistas concordariam, na medida em que ela considera os desiderata básicos do fisicismo não reducionista, a saber, não reducibilidade de propriedades e ontologia material da mente.
} 
argumenta comumente nos debates; tem-se, portanto, um argumento em favor do epifenomenalismo, ao invés de um argumento em favor da causação mental.

\section{4 - O Argumento de Superveniência para o Epifenomenalismo e a Causação Descendente}

Até aqui, eu considerei as variedades supervenientista e emergentista de argumentos materialistas que são associados à relação físico-para-a-mente. Nesta seção, eu gostaria de considerar a relação inversa, a relação mente-para-o-físico, isto é, a causação mental, com vistas a apoiar melhor minha justificativa para a preferência ontológica pelo dualismo elementar como uma premissa da tese monadista. Especificamente, situo a questão da exclusão causal com vistas a argumentar que, ao estabelecer a tese principal segundo a qual a relação mente-corpo é explicada por meio de agregação superveniente de unidades substanciais chamadas mônadas, o substancialismo (ou monadismo) evita a questão da exclusão causal da mente, uma questão que é levantada na interpretação fisicista da relação mente-para-o-físico. Tal como é bem sabido no debate sobre a causação mental: "O problema é se a ideia principal de causação descendente é inteligível: podemos coerentemente pensar que a existência de Y (ou sua instanciação) é completamente dependente de uma propriedade $\mathrm{X}$ mais básica e que, no entanto, $\mathrm{Y}$ tem um poder causal para influenciar X ?” (Pihlström, 2002, p. 144).

A questão acima pode ser considerada uma dificuldade essencial do emergentismo contemporâneo que esposa a causação descendente. Outro autor, corroborando a opinião geral na literatura, assim descreve a problemática da incompatibilidade dos desiderata do materialismo analítico: "Um dos diversos problemas concernentes à possibilidade da causação mental é que a causa potencial de uma propriedade superveniente parece ser 
absorvida pela sua base subveniente se tal base e sua propriedade superveniente não são idênticos" (Schröder, 2007, p. 221).

A questão de incompatibilidade tem sido bastante discutida. Alguns autores ${ }^{41}$ recentemente propuseram que os desiderata básicos do emergentismo podem ser reconciliados mediante uma redefinição do conceito de propriedade, que permite encontrar uma saída ao impasse deixado pelo dilema construtivo de Kim.

No desafio colocado pelo epifenomenalismo à questão dos poderes causais da mente, existem duas teses de causação descendente que devem ser consideradas:

(F1) Eficácia Causal dos Supervenientes: Os supervenientes têm influências causais sobre seus subvenientes de modo que existe uma conexão necessária (que se coloca em questão aberta) dos supervenientes com os subvenientes.

(F2) Eficácia Causal dos Emergentes: As propriedades mentais têm influência causal sobre suas propriedades basais físicas.

O epifenomenalismo tem sido considerado como uma implicação do fisicismo nãoreducionista. Em contraposição, existe uma notável passagem que mostra que a emergência e a superveniência da mente requerem a causação descendente. Eu chamo uma tal passagem de argumento para requerimento de eficácia causal da mente:

Mas por que o emergentismo e o fisicismo não-reducionista estão comprometidos com a causação descendente do mental para o físico? Aqui está um breve argumento que mostra porquê. Neste ponto sabemos que, no emergentismo, as propriedades mentais devem ter novos poderes causais. Estes poderes devem manifestar-se causando ou propriedades físicas

\footnotetext{
${ }^{41} \operatorname{Kim}$ (2011, correspondência pessoal) e Yoo (2008).
} 
ou propriedades mentais. Se são as primeiras, isto já é causação descendente. Assuma que a propriedade mental $\mathrm{M}$ cause outra propriedade mental $\mathrm{M}^{*}$. Eu mostrarei que isto é possível somente se $\mathrm{M}$ causa alguma propriedade física. Note primeiro que $\mathrm{M}^{*}$ é um emergente; isto significa que $\mathrm{M}^{*}$ é instanciada em uma dada ocasião porque uma certa propriedade física $\mathrm{P}^{*}$, sua base emergente, é instanciada naquela ocasião. Em vista da dependência emergente de $\mathrm{M}^{*}$ sobre $\mathrm{P}^{*}$, então, o que devemos pensar de sua dependência causal de $\mathrm{M}$ ? Eu acredito que estas duas alegações concernentes a porque $\mathrm{M}^{*}$ está presente nesta ocasião devem ser reconciliadas, e que a única forma viável de realizar isto é supor que $\mathrm{M}$ causou $\mathrm{M}^{*}$, pela causação de sua base de emergência $\mathrm{P}^{*}$. Em geral, o princípio envolvido ali é este: a única forma de causar a instanciação de uma propriedade emergente é causando a instanciação de sua base de emergência. E isto significa que a causação de "mesmo-nível" de uma propriedade emergente pressupõe a causalidade descendente de sua base emergente. $\mathrm{Eu}$ acredito que este argumento permanece plausível quando a emergência é substituída pela realização física em lugares apropriados (Kim, 1992, p. 136).

A persuasão desse argumento de requerimento de eficácia causal tem tornado a causação mental uma questão central da filosofia da mente. $\mathrm{O}$ epifenomenalismo, por seu turno, tem desafiado a tese do realismo mental, ou seja, a doutrina de que a mente muda causalmente o universo físico. No entanto, isso pode ser considerado uma dificuldade do epifenomenalismo fisicista, pois resulta numa exclusão do mental do universo, contrariamente às nossas intuições mais fundamentais. Este problema da exclusão consiste da questão de como é possível que um estado mental sobreveniente seja causalmente eficaz, assumindo-se que todo evento físico seja completamente determinado por causas físicas.

Uma tentativa de, em certa medida, salvar a eficácia causal da mente tem sido proposta no contexto de uma "explicação de programa" (program explanation), proposto por alguns fisicistas contemporâneos. Uma causa pode ser relevante sem ser propriamente eficaz, desde que ela "programe" a ocorrência do efeito. Esta abordagem salva em parte a relação causal da mente com o mundo, mas ainda compromete a plena força causal da mente em meio ao universo físico. Seus proponentes, que ainda são céticos em relação à eficácia causal da mente, apresentam sua abordagem da seguinte maneira: 
A quarta assunção é que o único caminho no qual uma propriedade pode ser causalmente relevante para um efeito é ser causalmente eficaz para sua produção. De modo a resistir a esta assunção, este artigo traça uma abordagem da relevância causal sob a qual uma propriedade pode ser causalmente relevante sem ser causalmente eficaz. De acordo com tal abordagem, a realização de uma propriedade pode programar a ocorrência de um efeito sem de fato contribuir para sua produção (Jackson \& Pettit, 1990, pp. 107-8).

Os autores pressupõem que a eficácia causal do universo mental sobre o universo físico é relevante para a explicação da relação mente-corpo, uma vez que eles oferecem uma teoria de programação de eficácia causal por meio de uma teoria de relevância causal.

Nesta seção, devo avaliar a assunção subjacente e os pressupostos da tese da exclusão causal. Na avaliação da assunção, vou argumentar pela negação da concepção determinista básica pressuposta no princípio de exclusão que conduz ao epifenomenalismo, e pela aceitação da chamada "sobredeterminação causal" (que definimos no item B3, na seção I.2). Argumento que se se pressupõe o dualismo elementar como premissa do monadismo, o argumento de exclusão causal, contra-intuitivo do ponto de vista das ciências psicossomáticas e do senso comum, consegue ser criticado em suas fundamentos. Tirando as conclusões, sugiro que o dualismo elementar permite a possibilidade de a mente fazer escolhas em meio ao mundo físico, concordando com as intuições do senso comum e das ciências psicossomáticas de que mente altera o mundo corporal.

Nas visões do senso comum e das ciências psicológicas, a mente muda o mundo de alguma forma. Mas, na metafísica da causação mental, existe dúvida sobre como a mente tem um lugar e muda o mundo físico. Portanto, não há dúvida sobre a importância das questões levantadas no debate em torno do argumento de superveniência. ${ }^{42}$ Neste debate, existe um argumento crucial que leva ao epifenomenalismo, de forma que a mente é

${ }^{42}$ Cf. Kim (1998, 2000), Sturgeon (1998, p. 1), Heil (1992), Crane (2003), Kim (2003), Block (2003) e Bontly (2002). 
causalmente evitada. Refiro-me aqui ao argumento de superveniência, também chamado de "argumento mestre" (master argument) ${ }^{43}$, que pode ser descrito por meio das teses seguintes:

(G1) Superveniência Psicofísica: $\mathrm{M}$ supervém a $\mathrm{P}$ e $\mathrm{M}^{*}$ supervém a $\mathrm{P}^{*}$.

(G2) Causalidade em Geral: M, e nenhum outro evento, causa $\mathrm{M}^{*}$; P, e nenhum outro evento, causa $\mathrm{P}^{*}$.

Então, desde que nenhum outro evento cause $\mathrm{P}^{*}$.

(G3) Preempção Causal Psicofísica: $\mathrm{P}$ evita que M cause $\mathrm{P}^{*}$, e que cause qualquer outro evento.

Portanto:

(G4) Epifenomenalismo do Mental: M é excluído causalmente ou não tem eficácia causal.

Muitos filósofos propuseram um escrutínio deste $\operatorname{argumento}^{44}$, que é realmente desafiador. As inferências do argumento são guiadas pelos princípios mínimos com os quais muitos fisicistas estão comprometidos: o fechamento causal do domínio físico e o princípio de exclusão causal. O fechamento assere que para toda efeito físico só existe um conjunto de causas de natureza também física para tal efeito. A exclusão assere que se um

\footnotetext{
${ }^{43}$ Introduzido primeiramente por Kim (1976). Cf. Crisp \& Warfield (2001).

${ }^{44}$ Importantes para a discussão do epifenomenalismo são: Block (1990), Yablo (1992), Kim (1993, 2000, 2003, 2005), Sturgeon (1998), Bonty (2002) e Block (2003).
} 
evento é causa de um efeito físico, não há outra causa - isto é, esta dever ser excluída para tal efeito físico.

Focalizemos a principal assunção e o pressuposto que fundamentam o segundo princípio, que contribui para a consequiência de epifenomenalismo e para outras dificuldades cruciais, tais como a generalização da exclusão do mental (Block, 1990, 2003) e a drenagem de causas do universo físico (Block, 2003; Kim, 2003, 2005). Estas dificuldades são expressas argumentativamente com veremos adiante e reforçam a necessidade de revisão do fisicismo contemporâneo.

De acordo com alguns filósofos (Kim, 2000, p. 12; Crane, 2003, palestra 1), a abordagem fisicista não-reducionista da causação compartilha um certo número de princípios, como os que se seguem:

(H1) Ontologia Física: Todas as entidades que existem são as partes próprias da matéria básica e seus agregados.

(H2) Dualismo de Propriedades: As propriedades mentais, quando originadas no curso evolutivo de uma agregação evolutiva, são irredutíveis às propriedades físicas.

(H3) Superveniência Psicofísica: Não há mudança mental sem que haja mudança física.

A par destas assunções, como nos casos dos argumentos da superveniência e da emergência, existe uma assunção fundacional crucial, qual seja, a tese da completude da 
física $^{\mathbf{4 5}}$, que poderia presumivelmente explicar a natureza da causação mental. A ideia de que a física futura alcançará um estado de completude causal (explicativa) é comprometida com uma assunção ontológica e também com uma outra assunção, de natureza metodológica.

Com relação à assunção ontológica, devemos considerar três pontos. Primeiramente, existiria a primazia ontológica do universo físico, sendo tal universo composto de partículas elementares clássicas (sendo, no fisicismo, "partículas" interpretadas, de um modo um tanto genérico, como um "pedaços de matéria” - bits of matter - existentes no nível básico, partículas estas que compõem os níveis superiores estratificados). Em segundo, a agregação de partes próprias físicas da matéria (definíveis numa espécie de mereologia física) é explicável via determinação causal, isto é, a doutrina de acordo com a qual para toda causa deve haver um, e um só, efeito (Kim, 1993, ensaio 1; Heil, 1992, cap. 4). Em terceiro, se presumivelmente a física alcançar um estado ideal de completude, tal como requerido pela tese de completude, tal teoria poderia explicar tudo.

Eu agora avalio brevemente as assunções sobre a causação pressupostas pelo funcionalismo, que fundamenta os argumentos de superveniência que conduzem ao epifenomenalismo. Especificamente, esta teoria se segue da assunção de que os relata causais consistem apenas de eventos que, de acordo com as assunções de muitos autores, são instanciações de propriedades (cf. Kim, 1993, ensaio 1), propriedades estas que são instanciadas deterministicamente. Podemos agora evitar o epifenomenalismo, no argumento de exclusão, por não pressupor que as relações causais sejam relações determinísticas, quer dizer, pela recusa de que elas sejam concebidas de forma a excluir sobredeterminações causais.

${ }^{45}$ Cf. Papineau $(2001,2003)$ para uma discussão da tese de completude e da metafísica da causação. 
Com relação à assunção metodológica da completude da física, podemos dizer que a imagem da causação mental estabelecida no fisicismo constitui a imagem funcionalista da causação, e tal imagem tem sido colocada como premissa na interpretação fisicista do problema mente-corpo descrito como tese de superveniência. Nesta imagem, a mente é considerada como uma apropriada descrição funcional ${ }^{\mathbf{4 6}}$, descrição que identifica o mental enquanto instanciável como uma infinidade de estruturas físicas, tal como é exigido pela tese de realizabilidade múltipla.

Uma vez que consideramos o argumento mestre acima, podemos agora mencionar o argumento de exclusão generalizada (the generalization argument), bem como o outro argumento que se segue dele, aquele de drenagem causal (drainage argument), os quais implicam um cenário totalmente epifenomênico, perigoso para as humanidades, contrariando as intuições mais simples do senso comum e das ciências psicológicas, como já salientamos no início desta seção.

Este complexo de questões está resumida na seguinte passagem de Block (2003, p. 133):

A questão é se é uma consequência do Argumento de Exclusão Causal que toda a causação em nível macro (ou seja, a causação acima do nível da física fundamental) seria uma ilusão, com todos os aparentes poderes causais do mental e de outras propriedades macroscópicas drenando [draining] para o nível fundamental da física. Argumentarei que tal consequência nos daria razão para rejeitar o Argumento da Exclusão Causal. Mas há também um desafio mais difícil, a acusação de que "os poderes causais drenariam para um poço sem fundo e não haveria causação em lugar nenhum" [citando Kim, 1998, p. 81].

Na próxima seção, examinaremos a relação da sobredeterminação, que dará apoio à justificação da escolha do dualismo elementar.

\footnotetext{
${ }^{46}$ A análise funcional pode ser comparada com a doutrina do mecanicismo, assumindo-se que a noção de "instrução" da máquina na teoria funcionalista de Putnam corresponde às relações causais da natureza da física clássica.
} 


\section{5 - Sobredeterminação Causal e Escolha}

Esta seção pode ser considerada como um peso favorável para a justificação da escolha do dualismo elementar. Queremos situar aqui a doutrina compatibilista e favorecer a posição da sobredeterminação causal, controversa no debate contemporâneo.

Nas discussões sobre a liberdade, três posições são amplamente discutidas, a saber: libertários, deterministas e compatibilistas. Os libertários correspondem à espontaneidade do arbítrio (sponte sua, em latim), sem qualquer determinação da natureza ou de autoridade. Os deterministas defendem a pura determinação alheia ou da natureza, sem a espontaneidade. E os compatibilistas esposam a ideia da compatibilidade da determinação natural ou moral com o arbítrio. Nesta, seção, argumentamos que a sobredeterminação pesa favoravelmente para a intuição compatibilista, e este compatibilismo favorece a escolha do dualismo elementar.

Podemos exemplificar a intuição compatibilista em Popper, Kant e Davidson. Em Popper, temos uma vigorosa argumentação em favor do arbítrio, fundamentada em sua teoria dos três mundos. O argumento de Popper em favor do compatibilismo, que pode ser comparado às fontes da sobredeterminação das causas, pode ser reconstruído como se segue:

(I1) Em princípio, as ações humanas podem ser explicadas em termos de determinismo, indeterminismo e liberdade humana. 
(I2) Se o determinismo é verdadeiro, então todas as ações humanas - incluindo nossos pensamentos e criatividade - são tão perfeitamente previsíveis quanto a conduta dos relógios. Mas as ações humanas tais como pensamentos, decisões, escolhas e criatividade não são completamente previsíveis como relógios. A física quântica mostra que existem eventos aleatórios. Portanto, o determinismo é falso.

(I3) Se o indeterminismo fosse verdadeiro para todos os sistemas, então as ações humanas seriam aleatórias e tão extremamente imprevisíveis como bolas de loteria ou uma medição quântica. Contudo, as ações humanas não são tão incompletamente imprevisíveis. Podemos, por exemplo, predizer com acerto onde nossos amigos estariam em um certo tempo, se soubéssemos seus objetivos e agendas para o dia.

(I4) Ações humanas livres ou moralmente relevantes são explicáveis e razoavelmente previsíveis em termos de papeis de "controles plásticos", como ideais, valores, teorias, constituições, metas, objetivos, planos e agendas usadas como ideias regulativas, etc.

(I5) Portanto, a melhor explicação para a conduta humana não é nem determinismo nem indeterminismo, mas a liberdade ou livre-arbítrio (de I1 a I4, e inferência para a melhor explicação $)^{47}$.

$\mathrm{O}$ argumento popperiano acima certamente satisfaz a intuição compatibilista em um referencial ontológico de três mundos, porque procura o posicionamento intermediário,

\footnotetext{
${ }^{47}$ Osei (1994, p. 6), que argumenta em favor da tese de que Popper seria um compatibilista.
} 
situado no mundo 3 (das produções intelectuais), entre a determinação semelhante aos relógios no mundo 1 (físico) e o indeterminismo nebuloso no mundo 2 (mental).

Kant, outro exemplo proeminente, procurou também argumentar em favor da intuição compatibilista, como lemos na célebre passagem da tese compatibilista:

Embora daqui resulte uma dialética da razão, uma vez que, pelo que respeita à vontade, a liberdade que a esta se atribui parece estar em contradição com a necessidade natural, e nesta encruzilhada a razão, sob o ponto de vista especulativo, acha o caminho da necessidade natural muito mais plano e praticável do que o da liberdade, no entanto sob o ponto de vista prático, o caminho de pé posto da liberdade é o único por que é possível fazer uso da razão nas nossas ações e omissões; pelo que será impossível a mais sutil filosofia como à razão humana mais vulgar eliminar a liberdade com argumentos sofísticos. Há, pois, que pressupor que entre liberdade e necessidade natural dessas mesmas ações humanas se não encontra nenhuma verdadeira contradição; pois não se pode renunciar nem ao conceito da natureza nem o da liberdade (Kant, [1785] 1980, $3^{\text {a }}$ seção, p. 156).

Como vemos, tal passagem introduziu o compatibilismo, que influenciaria, conforme mostrou a história da filosofia, os idealismos dialético e fenomenológico. Outro filósofo, Davidson, contemporaneamente, capturou a intuição compatibilista, num célebre ensaio:

Eventos mentais, tais como percepções, lembranças, decisões e ações, resistem a serem capturados na rede nomológica da teoria física. Como pode este fato ser reconciliado com o papel causal dos eventos mentais no mundo físico? Reconciliar a liberdade com determinismo causal é um caso especial do problema, se nós supusermos que o determinismo causal implica captura na rede nomológica, e a liberdade requer escapar desta rede. Mas a questão mais ampla pode permanecer viva mesmo para alguém que acredita que uma análise correta da ação livre não revela conflito com o determinismo. Autonomia (liberdade, auto-regra) pode ou não conflitar com o determinismo; anomalia (falha a subsumir a uma lei) é, pareceria, outra questão. Eu parto da assunção de que ambos dependência causal e a propriedade de ser anômalo [anomalousness] dos eventos mentais são fatos inegáveis. Meu propósito é, portanto, explicar, face a dificuldades aparentes, como isto é possível (Davidson, 1980, p. 207). ${ }^{48}$

\footnotetext{
${ }^{48}$ Em correspondência pessoal em 2003, Davidson me explicou que, em seu artigo seminal de 1970, não estava precisamente interessado em defender um ponto de vista kantiano, mas apenas concordar com o fato de que Kant considerou, em sua obra, que ambos determinismo e livre-arbítrio seriam verdadeiros.
} 
Vemos assim como as passagens acima aludem claramente ao compatibilismo. Pensamos que Popper, Davidson e Kant apontam para uma direção relevante para a atual filosofia da mente. Em nosso caso, pensamos que a sobredeterminação causal aponta também para o compatibilismo. Consideremos, brevemente, o que seja a sobredeterminação causal (causal overdermination). Uma variedade relevante de sobredeterminação ocorre quando há duas ou mais causas numericamente distintas e independentes para um efeito a ser determinado por tais causas. Uma explicação clara pode ser dada como se segue: "A independência refere-se ao fato de que o mecanismo destas causas sobredeterminantes estão separados. A sobredeterminação independente ocorre quando propriedades causalmente relevantes de objetos, regiões, ou ao longo de diferentes caminhos causais, são suficientes para o mesmo efeito"49.

As sobredeterminações são geralmente consideradas um problema para a tradição fisicista, pelo fato de predominar a doutrina determinista ${ }^{\mathbf{5 0}}$. Mas, a nosso ver indica uma alternativa compatibilista, pois se há possibilidade de haver inúmeras causas numericamente distintas para a determinação de um certo efeito, temos um meio termo entre o arbítrio da vontade e a pura determinação da natureza.

Permitida a proliferação qualitativa de causas na sobredeterminação, assim se terá maior variedade para possibilidade do arbítrio da vontade e, portanto, maior liberdade de escolha. Quanto menor sobredeterminação, menor a influência do arbítrio da vontade e, portanto, maior determinação da natureza causal. E assim também com as escolhas que

\footnotetext{
${ }^{49}$ Funkhouser (2003, p. 337). Esta variedade de sobredeterminação causal apontada pela taxonomia de Funkhouser é especialmente relevante para a justificação da escolha do dualismo elementar, e também por indicar premissas para se argumentar pelo compatibilismo.

${ }^{50}$ Para um estudo sobre o aspecto negativo da sobredeterminação causal para o fisicismo contemporâneo, ver Kim (1976, 2000), Papineau (2001) e Sider (2003).
} 
variam de acordo com a existência de possibilidades abertas da sobreterminação causal. Pode haver o que se poderia chamar de escolhas mínimas, com uma qualidade maior de determinação da natureza ou da autoridade alheia, ou maximais, para o caso contrário, dependendo da situação de compatibilidade entre o arbítrio da vontade e as determinações causais da natureza ou da razão (ou mesmo da força bruta).

Sem a sobredeterminação, não teríamos escolha em relação à totalidade de eventos ou universo, porque as sobredeterminações permitem a situação de que, para todo evento físico P, existem infinitamente muitas relações causais de $\mathrm{M}$ com um estado ou evento atualizável no mundo físico ${ }^{51}$, situação que permitiria escolhas, tal como requer a doutrina metafísica leibiniziana, de natureza teológica, da existência da infinidade atual.

A análise da causação mental acima realizada completa minha consideração da questão central da causação mental no debate em torno do problema mente-corpo. No que se segue, oferecerei caminhos para sair das dificuldades referidas nos debates sobre a superveniência, emergência e causação mental. Prosseguindo, vou considerar agora a justificativa para a escolha do dualismo elementar.

\section{6 - Uma Justificação da Escolha do Dualismo Elementar}

Agora que consideramos as principais dificuldades da superveniência, da emergência e da causação mental, eu gostaria de formular a justificativa para escolha do

\footnotetext{
${ }^{51}$ A assunção de objetividade do fisicismo e a questão correlata do lugar da mente na natureza foram claramente ressaltadas por Nagel (1986, caps. II e III). O papel causal do subjetivo foi desenvolvido posteriormente por Chalmers (1996, cap. 4, seção 4).
} 
dualismo elementar como uma opção que evita as dificuldades do fisicismo nãoreducionista, salientadas nas seções anteriores.

Como se tem mostrado, os argumentos de superveniência são fundamentados em: 1 - premissas funcionalistas que são vulneráveis às principais dificuldades dos enfoques funcionalistas do mental, quais sejam, o aspecto fenomenológico da experiência consciente, a irredutibilidade das propriedades funcionais de segunda ordem e a anomia do mental (liberdade); 2 - a tese da superveniência psicofísica, que não é adequada para capturar as intuições materialistas de dependência do mental em relação ao físico e, inversamente, a determinação do mental pelo físico. Além disto, mostrou-se que a relação de superveniência não é, de um ponto de vista lógico, metafisicamente profunda, e requer explicação, uma vez que apenas constitui uma maneira de formular a questão da relação mente-corpo. Os fundamentos 1 e 2 fazem com que o enfoque supervenientista seja uma fonte escassa para estruturar o materialismo na forma de uma tese de primazia do físico. Sem a tese de primazia, podemos evitar as implicações dos fundamentos 1 e 2 de uma vez, e tal argumentação pode ser feita se aceitarmos que sejam iguais as importâncias ontológicas do mental e da matéria física. Uma tal igualdade pode ser satisfeita pela escolha de uma variedade mais elementar de dualismo. Nessa linha de argumentação, o mental retorna ao universo físico e o regula autônomamente (segundo uma série monádica) e o materialismo fisicista se reduz apenas à materialidade da forma. Chamo a esta concepção de redução de "neutralização do fisicismo", a qual retomaremos nas conclusões do ensaio.

Com relação à teoria emergentista, vimos que esta tem, em essência, a dificuldade crucial da incompatibilidade entre irredutibilidade e dependência do mental em relação à base física. Ou seja, o fisicismo emergetista pressupõe a tese de primazia como uma base fundamental para formular o problema mente-corpo, mas ao mesmo tempo atribui poderes 
causais ao mental, o que leva à causação descendente e aos problemas decorrentes apontados por Kim e outros autores.

Por outro lado, se escolhemos o dualismo elementar, o mental e o físico se tornam ambos importantes para iniciar ontologicamente a explicação das relações mente-corpo. Eles se tornam interdependentes. Portanto, a questão da dependência do mental em relação ao físico não existe. E desde que ambos elementos, mental e físico, têm igual importância ontológica, a redutibilidade ou a irredutibilidade não precisam ser colocadas.

Em relação ao cenário epifenomentalista, colocado pelo debate contemporâneo sobre a causação mental, pode-se argumentar que o dualismo elementar não implica epifenomenalismo, tal como é o caso do fisicismo no argumento da exclusão. A assunção e a pressuposição de meu posicionamento (o primeiro relacionado com a natureza da causação e o segundo com a tese de completude da física) são cruciais para o entendimento das dificuldades do enfoque emergentista. O mental e o físico, tal como eles são concebidos de acordo com a assunção de dualismo elementar, não são reduzidos (em certo sentido do termo "redução") por meios causais que somente são descritos em termos deterministas, termos que parecem ser pressupostos por muitos fisicistas. De acordo com alguns filósofos ${ }^{52}$ que definiram a mônada ou substância simples e tentaram evitar as implicações do determinismo causal, é possível negar que as propriedades e os eventos juntos às substâncias interajam apenas causal e deterministicamente, uma interação que a tese de completude causal requereria.

Portanto, a justificação para a escolha do dualismo elementar como um esquema ontológico é que este é mais adequado para estruturar uma solução do problema mente-

\footnotetext{
${ }^{52}$ Cf. Leibniz ([1714] 1974, § 7, 11). Para uma clara explicação dos § 7 e 11, veja-se Savile (2000, p. 228).
} 
corpo, porque este evita que se tenha, tal como tentei argumentar, algumas dificuldades específicas dos argumentos supervenientistas e emergentistas para resolver o problema mente-corpo, argumentos estes que se fundam na tese de primazia do universo físico sobre o universo mental.

Assim, no que se segue, articularei minha visão, assumindo, então, que o dualismo elementar seja verdadeiro, e contrastá-lo-ei com a imagem fisicista do universo. O universo seria, dessarte, melhor configurado como uma infinidade de mônadas que estão relacionadas umas com as outras composicionalmente e são fisicamente correlacionadas; qualquer relação, incluindo a relação mente-corpo, deve ser considerada como uma relação monádica infinitária, isto é, como uma relação entre uma infinidade de mônadas. 


\section{Capítulo II}

\section{A Tese Composicional das Relações Psicofisicas}

Eu considerei no capítulo anterior a justificação para a escolha da assunção de dualismo elementar, ou dualismo formulado com base na relação parte-todo, por meio da discussão do materialismo contemporâneo referente às principais questões difíceis das doutrinas da superveniência, da emergência e do realismo mental, a saber, a primazia do físico, a inércia e o isolamento causais da mente e a inexplicabilidade da novidade da emergência da mente na natureza (acrescente-se, também, as questões da fenomenologia da consciência que não são examinamos neste ensaio). Parece que tais dificuldades, que têm sido bastante debatidas, residem em duas assunções que são derivadas da tese de primazia: primeiro, a ausência de importância ontológica do mental na principal base da substância monística - a matéria física - e, segundo, a existência de relações causais psicofísicas. É parte de minha estratégia avaliar estas duas assunções fundamentais do fisicismo contemporâneo.

Salientamos que a noção de substância monística permite-nos concordar, em parte, com o fisicismo, desde que se argumente em favor de duas teses, quais sejam: (a) - que a matéria física tem uma importância ontológica na composição e constituição das relações psicofísicas; (b) - que formas mais complexas do mental supervém à relação entre os elementos físico e mental. A par disto, acompanhando as discussões fisicistas, parece claro que a concepção monista e extensional de substância pressuposta pelo fisicismo contemporâneo está na base das dificuldades (esclarecemos tal concepção pressuposta mais adiante). 
Portanto, se queremos resolver algumas dificuldades que não estão presentes no senso comum e nas ciências psicológicas, ao menos em parte, temos que abandonar o monismo ontológico segundo o qual a mente inexiste ontologicamente, e propor, em favor do senso comum e das ciências psicológicas, outra variedade de monismo, o qual denomino "monismo monádico". Esta visão monista, que é compatível com o dualismo do mental e do físico interpretados como elementos fundamentais, seria a forma de evitar as dificuldades específicas dos argumentos de superveniência e de emergência para o fisicismo como doutrina das relações mente-corpo.

Agora a questão é: como desenvolver uma tal interpretação monista? Tal como fazem os fisicistas, os monadistas (da tradição hermética desde Giordano Bruno) têm que lidar com as questões da explicação e fundamento da superveniência psicofísica com vistas a defender o argumento para a explicação das relações mente-corpo. Na visão monística do monadismo, a superveniência do mental é uma questão lógico-ontológica de composição, e argumentarei também que o mental é considerado como um elemento basal ou ingrediente fundamental de uma tal composição.

Por “composição", eu entendo uma relação binária e psicofísica envolvendo dois aspectos: mereológico e holístico. Tais aspectos não se contradizem, na medida em que sejam considerados como diferentes aspectos da relação mente-corpo segundo o monadismo.

O primeiro deve ser descrito pela premissa mereológica. Parece-me que tal premissa necessita do esboço de algumas condições da mereologia, isto é, da lógica de acordo com a qual os todos não são mais do que a composição de partes, que determinam as propriedades desses todos. Tais condições são relevantes para oferecer um enfoque contemporâneo da relação mente-corpo como uma relação real de superveniência (tal como é desejado pelos 
fisicistas). No caso do monadismo, as formas mais complexas de mentalidade supervêm mereologicamente às mais simples, as substâncias monádicas.

A segunda relação composicional a ser explicada é holística, sendo o termo "holística" referente à doutrina de que os "todos substanciais" são ontologicamente independentes de, e determinantes de, propriedades, eventos e estados de suas partes. Esta premissa do argumento central deste ensaio se refere à composição dos simples, ou substâncias simples, ou mônadas. A mônada é um todo constituído de elementos semelhantes à mente (mind-like) e semelhantes ao físico (physical-like); as mônadas são unidades de composição dos agregados, uma composição que fundamenta, via relações mereológicas, a superveniência da mente. No que se segue, eu começo pela consideração das condições lógicas do holismo ontológico e, posteriormente, passo para consideração daquelas da mereologia, na medida em que tais condições sejam relevantes para a abordagem monadista do problema mente-corpo.

\section{1 - A Tese Composicional Holística ou o Holismo dos Simples}

No dualismo elementar, a mente e a matéria física são ambas interpretadas como elementos que têm a mesma importância ontológica para a explicação da relação mentecorpo como um todo substancial e verdadeiro (isto é, não mero agregado). Como eles compõem esta totalidade una? Esta me parece ser a questão fundamental que, uma vez respondida, pode apoiar uma abordagem monadista do relação mente-corpo. Nesta seção, eu indico aspectos de uma descrição lógica para a questão do holismo psicofísico e ontológico, como uma interpretação holística da noção de substância simples, uma noção 
que fundamentará a premissa ontológica para defesa da tese de que a relação mente-corpo é uma relação entre uma infinidade de mônadas ou simples (isto é, uma relação infinitária entre tais relata)

Para o propósito de enfocar a questão da substancialidade psicofísica, que é relevante para propor um começo para a solução do problema mente-corpo, o holismo dever ser interpretado de acordo com algumas condições lógico-metafísicas que são interpretadas de acordo com um modelo ontológico. Consideremos primeiramente algumas condições lógicas para uma entidade, um estado, uma propriedade ou uma substância ser holística.

Para começar, existe uma concepção do holismo que é expressa por meio da tese seguinte:

[...] será conveniente discutir uma tese familiar frequentemente associada com estes temas. De acordo com esta concepção, existe um tipo importante de todos individuais (físicos, biológicos, psicológicos, bem como sociais) distinguidos de outros pelo fato de que eles são "unidades orgânicas", e não simplesmente "agregados" de membros ou partes independentes. Todos deste tipo são frequentemente caracterizados pelo dito de que eles possuem uma organização em virtude da qual "o todo é mais do que a soma de suas partes" (Nagel, 1961, p. 380).

A noções de "parte", "todo" e de "mais do que a soma" é referida na passagem acima, na qual a noção de holismo é definido em termos de unidades "orgânicas" de "todos funcionais":

Todos orgânicos ou funcionais têm sido definidos em sistemas "cuja conduta não é determinada pela conduta de seus elementos individuais, mas onde as partes-processos são elas mesmas determinadas pela natureza intrínseca do todo" [Wertheimer, 1938]. O que é distintivo de tais sistemas, portanto, é que suas partes não interagem, e não possuem características, independentes umas das outras. Pelo contrário, supõe-se que suas partes são relacionadas de tal modo que alguma alteração de uma delas causa a mudança em todas as outras partes. Em consequência, diz-se que os todos funcionais são sistemas que não podem ser construídos a partir dos elementos pela combinação destes últimos seriatim, sem produzir mudanças em todos outros elementos. Ademais, tais todos não podem ter 
quaisquer partes removidas sem alterar tanto aquela parte como as partes restantes do sistema (Nagel, 1961, p. 391).

Em segundo lugar, existe uma concepção que esclarece ainda mais a noção de holismo ontológico e pode apoiar a noção de substância adequada para o monadismo. Temse argumentado (Esfeld, 1998, pp. 366-7; Smuts, 1926; Simons, 2003, parte III) que o holismo é definível para satisfazer as seguintes propriedades: compreensividade (o todo compreende suas partes), não-trivialidade (nem toda parte de um sistema interage com o todo, apenas certas partes interagem), sistematicidade ontológica (as partes de um todo têm uma existência sistemática ou existência relativa a um sistema holístico) e interdependência entre as partes (que se refere à tese ontológica sobre alguma dependência recíproca entre as partes de um todo). A seguinte definição parece capturar a noção inicial de holismo:

Assim, como um ponto de partida, vamos considerar um sistema como holístico se, e somente se, as coisas que são suas partes têm algumas das propriedades que são características dela somente dentro do todo. Com relação à instanciação destas propriedades, cada uma destas coisas é dependente da existência de outras coisas juntas para que, com elas, constitua o todo da espécie em questão (Esfeld, 1998, p. 367).

O foco sobre a dependência holística é relevante para a articulação do monadismo. É necessário para a condição de ser um sistema holístico que as partes compartilhem uma espécie de dependência dentro do todo. Alguns filósofos ${ }^{\mathbf{5 3}}$ propuseram que as partes de um sistema holístico devem satisfazer a dependência ontológica genérica, tal como expressa na fórmula:

$$
\forall x(\mathrm{~F} x \rightarrow \exists y(\mathrm{G} y \wedge y \neq x)) \wedge \diamond \exists x \mathrm{~F} x \wedge \neg \exists x \mathrm{G} x
$$

\footnotetext{
${ }^{53}$ Simons (2003), que é modificado por Esfeld (1998, p. 369).
} 
que pode ser expressa na linguagem natural como composta de uma cláusula principal e duas cláusulas adicionais, como se segue. É necessário que se existe algo que é $\mathrm{F}$, então existe outro algo que é G. A isto se acrescenta a afirmação de que é possível que haja algo que seja F, e também a de que não é necessário que exista algo que seja G.

No caso ao qual nos referimos acima, F e G são propriedades de indivíduos, digamos $x$ e $y$, os quais pertencem ao sistema holístico, e estas propriedades são genericamente dependentes umas das outras. Além disto, estas propriedades têm as seguintes características:

(J1) Designação rígida: As propriedades podem ser substituídas por designadores rígidos denotando espécies naturais.

(J2) Identidade: As propriedades F e G podem ser idênticas.

(J3) Transitividade: A relação de propriedade é transitiva (para um sistema com mais de dois indivíduos): necessariamente, se $x$ é $\mathrm{F}$ implica $y$ é $\mathrm{G}$, e $y$ é $\mathrm{G}$ implica $z$ é H, então $x$ é F implica $z$ é H. Em notação lógica:

$$
(((\exists \mathrm{xFx} \rightarrow \exists \mathrm{yGy}) \wedge(\exists \mathrm{yGy} \rightarrow \exists \mathrm{zHz})) \rightarrow(\exists \mathrm{xFx} \rightarrow \exists \mathrm{xHz}))
$$

(J4) Simetria: Se nós aplicamos a fórmula às partes do sistema holístico, temos que conceber que a dependência ontológica genérica é uma relação simétrica: é necessário que, se a existência de um $x$ que é F implica na existência de algum outro indivíduo que é G; então, a existência de um y que é $\mathrm{G}$ implica na exsitência de algum outro indivíduo $x$ que é F. O que nós estamos procurando é 
uma espécie de dependência que capture a forma na qual as partes de um sistema holístico são dependentes entre si. Em notação lógica:

$$
((\exists x \mathrm{~F} x \rightarrow \exists y \mathrm{G} y) \rightarrow(\exists y \mathrm{G} y \rightarrow \exists x \mathrm{~F} x)) .
$$

(J5) Modelos Físicos ou Metafísicos: A interpretação da necessidade e da possibilidade modais pode ser feita para todo mundo metafisicamente possível, ou naqueles fisicamente possíveis (Esfeld, 1998, p. 369).

Tais propriedades definem a chamada dependência ontológica genérica entre as partes de um sistema holístico, sendo a simetria uma condição de interesse para o monadismo, dado que esta caracteriza a noção de como as partes de um sistema holístico são interdependentes. A propriedade de dependência ontológica genérica é característica do sistema holístico, que funciona como um todo funcional ou unidade orgânica das partes, e é definida da forma seguinte:

Considere um sistema da espécie $\mathrm{S}$ e suas partes constituintes. Para todo constituinte de $\mathrm{S}$, existe uma família de propriedades qualitativas que fazem alguma coisa ser um constituinte de $\mathrm{S}$ no caso em que exista um arranjo conveniente. S é holístico se e somente se a seguinte condição é satisfeita por todas as coisas que são seus constituintes: com respeito à instanciação de algumas das propriedades que pertencem à família de propriedades, uma coisa é ontologicamente dependente de uma maneira genérica da existência atual de outras coisas juntas arranjadas, de uma tal forma que exista S (Esfeld, 1998 p. 375).

Com vistas a considerar o monadismo, é necessário considerar a questão da adequação da definição para o caso de uma substância simples vista contemporaneamente como um sistema $\mathrm{S}$, que nos interessa especificamente. Na tradição aristotélica ${ }^{\mathbf{5 4}}$, sabe-se que as substâncias são concebidas como todos verdadeiros cujas partes são definidas como

\footnotetext{
${ }^{54}$ Refiro-me à Metafísica, livro Z. Cf. Wedin (2000).
} 
essenciais ou acidentais, como formal e material, segundo uma fenomenologia da mudança, regida por uma lógica da mudança e também por uma dialética da mudança, e uma metafísica que busca a essência, a permanência e subsistência das coisas reais.

O todo verdadeiro é definido com uma certa lógica, que deve ser holística, pois tal todo verdadeiro é contrastado com um falso todo, um agregado instantâneo de partes, um todo meramente mereológico, que não pode substituir um todo verdadeiro. Se as partes das substâncias são concebidas como subsistindo num todo verdadeiro, então uma tal concepção satisfaz a condição de interdependência genérica das partes essenciais (para as partes de um sistema holístico que permanecem) e acidentais (para aquelas que mudam ou são temporais) num todo substancial, tal como é requerido pela dependência ontológica genérica entre as partes de um sistema holístico. ${ }^{55}$

Portanto, para nossos propósitos, segue-se da lógica holística da substância que, de acordo com a caracterização das partes constituintes de um todo $\mathrm{S}$ proposto, pode-se construir a forma da dependência genérica da seguinte forma:

(K1) Modelo Modal de Essencialismo: Considere $x$ e $y$, que são respectivamente as partes essencial e não-essencial do todo verdadeiro (ou substância simples) S. Neste caso, S exibe $x$ no mundo atual bem como em todo mundo possível; e exibe $y$ no mundo atual, mas existe pelo menos um mundo possível no qual $\mathrm{S}$ não exibe $y .^{56}$

\footnotetext{
${ }^{55}$ Considere, por exemplo, Simons (2003), parte III, para a definição lógica de substancialidade.

56 A dependência genérica da forma estabelecida acima pressupõe a noção do essencialismo modal. Mas, neste ensaio, dada a distinção metafísica e lógica entre essência nominal e essência real, devo confessar que o essencialismo real, o qual se referiria à parte essencial real da mônada, seria mais
} 
(K2) Dependência Ontológica Genérica: $x$ e $y$ são partes constitutivas de S e, portanto, elementos de S.

(K3) Assunção Ontológica: Tais elementos são a mente e a matéria física.

(K4) Definição Analítica da Mônada: A mônada é S.

Portanto,

(K5) Tese Composicional Holística: A relação entre a mente e o físico é uma relação composicional cujos relata são os elementos mental e físico, que são partes constituintes de um sistema holístico S, a substância simples ou mônada.

Esta interpretação completa a caracterização das condições de composicionalidade para a premissa composicional holística, tendo em vista estabelecer a tese monadista deste ensaio. Temos a formulação do holismo da substância simples, de acordo com as condições de um indivíduo sendo parte de um sistema holístico. A definição do simples é agora adequada para a definição de outro aspecto da relação mente-corpo como uma relação composicional: a composição mereológica de seres pensantes a partir de mônadas simples. As mônadas estão agora na principal base metafísica das relações mente-corpo. Eu denomino a tese acima referida de tese do holismo psicofísico.

Tendo esboçado a definição de substância, é necessário, com vistas a defender a principal tese do monadismo, definir o aspecto mereológico da composição dos corpos a partir de seus constituintes básicos, as mônadas fundamentais, os simples ontológicos, isto é, definir a premissa composicional mereológica.

adequado para articular um argumento em favor do holismo psicofísico monadista neste ensaio. Para uma defesa contemporânea do essencialismo real, veja-se Oderberg (2007). 


\section{2 - A Tese Composicional Mereológica ou a Mereologia dos Compostos}

A mereologia é a teoria lógica das relações entre parte e todo, na qual as partes determinam todas as propriedades do todo. Podemos dizer que, em um dado sistema de mereologia, as propriedades do todo supervêm às propriedades de suas partes. Tal é o ideal da superveniência mereológica e a tese composicional assere que os corpos físicos supervêm mereologicamente sobre a composição dos simples, ou mônadas. Com vistas a argumentar detalhadamente em favor de tal tese, poderíamos apresentar um sistema de mereologia fundamentado em noções relacionadas aos monadismos clássicos, para tornar a mereologia relevante para uma interpretação contemporânea do monadismo.

Qualquer sistema mereológico tem uma definição da noção fundacional, qual seja, a de "ser parte de" um todo, e também a consequente definição de suas operações lógicas, as operações mereológicas. Os sistemas mereológicos variam de acordo com as suposições mereológicas formuladas com relação à noção de parte e às operações definidas.

Uma excelente maneira de se familiarizar com um sistema lógico de mereologia é consultar o artigo de Varzi (2009), que inicia apresentando um sistema fundamental de mereologia, ou "mereologia de fundamento" (ground mereology) (teoria M), que é um núcleo comum compartilhado por qualquer sistema mereológico (teoria da relação entre parte e todo). O sistema é definido no cálculo de predicados de primeira ordem com igualdade. O predicado fundamental é P, ser "parte de", de maneira que Pxy significa que $x$ é parte de $y$. Quais são as propriedades que definem esta relação? É razoável que sejam as seguintes:

(P1) Reflexividade: Pxx. Ou seja, qualquer coisa é parte de si mesma. 
(P2) Transitividade: $($ Pxy $\wedge$ Pyz $) \rightarrow$ Pxz. Por exemplo, se a semente é parte da flor, e a flor é parte da planta, então a semente é parte da planta.

(P3) Antissimetria: $(\mathrm{Pxy} \wedge \mathrm{Pyx}) \rightarrow \mathrm{x}=\mathrm{y}$. Ou seja, duas coisas distintas não podem ser partes uma da outra.

A partir daí, definem-se outras propriedades, como parte própria PP, átomo mereológico (que não tem partes), soma mereológica, extensão, etc. Referimos o leitor que quiser explorar a formulação lógica das definições e axiomas relevantes para Varzi (2009).

Outra propriedade importante é o princípio da extensionalidade, incorporada na chamada "mereologia extensional clássica", ou teoria EM: "duas coisas quaisquer que têm as mesmas partes próprias são idênticas entre si”,57 . Este é um princípio fundamental nos sistemas mereológicos. Numa interpretação extensional, a noção de parte não depende de aspectos intensionais, por exemplo, modalidades temporais.

No caso do monadismo, o princípio da extensionalidade não seria válido, dado que qualquer objeto substancial tem partes que não mudam, quais sejam, as partes essenciais, e também partes que mudam no tempo, partes que estão em fluxo fisico ou mudança espaçotemporal, tal como se formula no célebre problema do navio de Teseu. Neste caso, o mesmo navio teria partes diferentes (em tempos diferentes).

Portanto, o significado da relação mereológica básica deve obedecer a noções modais ligadas ao chamado "essencialismo modal". Assim, para o caso de substâncias, o princípio de extensionalidade não vale, porque as substâncias são objetos que têm partes temporais, os acidentes, e também têm partes essenciais, que persistem temporalmente sob

\footnotetext{
${ }^{57}$ O leitor pode comparar o sistema de Varzi (2009) com o de Leśniewski, o qual é fundamentado no axioma de que nenhum objeto é parte de si mesmo, do qual se segue como um resultado o teorema I de seu sistema de mereologia extensional clássica, o qual lida com a noção de ingrediente, e prova a tese "Todo objeto é um ingrediente de si mesmo".
} 
a mudança das partes acidentais. $\mathrm{E}$ as considerações intensionais permanecem mesmo se $\mathrm{o}$ fluxo das partes é expresso extensionalmente por meio de considerações quadridimensionais, isto é, assumindo-se que, segundo o quadrimensionalismo mereológico, os objetos têm partes temporais, ou uma quarta dimensão complementar às três dimensões do espaço, como se faz na Teoria da Relatividade. Portanto, a mereologia apropriada para a descrição das relações composicionais das substâncias composta e simples deve ser intensional, tal como exige os essencialismos modal e real.

Devemos agora relacionar a mereologia com a concepção de mônada, ou substância simples. Na seção II.1, definimos a noção holística de substância simples, que é constituída pelos elementos físicos e mentais, de uma forma que é possível considerar os simples como compondo os compostos por meio de relações de parte e todo. É também possível reconsiderar a questão de como o mental supervém sobre as relações de uma variedade metafisicamente infinita de simplíssimos. O conceito mereológico de superveniência é considerado mais interessante para o estudo das relações mente-corpo porque, de acordo com o conceito, as propriedades de um todo - a substância psicofísica composta supervém às propriedades de suas partes, quais sejam, os elementos constitutivos físico e mental. Aqui, a tese de superveniência dos seres psicofísicos compostos sobre uma infinidade atual de simples monádicos pode ser defendida argumentando-se de acordo com a definição mais simples de superveniência mereológica: não há mudança nas propriedades de um todo (os agregados monádicos) sem que haja mudança nas propriedades de suas partes composicionais (as unidades monádicas).

Com vistas a propor parte da resposta à questão de como a mente é relacionada ao corpo, seria necessário propor algumas condições mereológicas de agregação fenomenológica de unidades monádicas. Alguns filósofos propuseram que a monadologia 
clássica fornece tais condições de composicionalidade. Burkhardt \& Degen (1990, p. 10), por exemplo, afirmam o seguinte: "As considerações mereológicas empreendidas até este ponto são baseadas somente num pequeno fragmento das ideias mereológicas de Leibniz, isto é, aquelas que concernem à composição parte-todo de complexos (agregados ou reuniões) de mônadas".

Estes autores propõem um sistema de mereologia infinitário e semi-atomístico, que se inspira na doutrina leibniziana das mônadas. Abstemo-nos de reproduzir os axiomas relevantes, que podem ser consultados em Burkhardt \& Degen (1990). Teceremos, no entanto, algumas considerações sobre as definições e axiomas do sistema de mereologia de Burkhardt \& Degen, tendo em vista a formulação da premissa mereológica de meu argumento em favor do monadismo.

No que tange às definições, o sistema de mereologia começa com a operação primitiva de parte própria PP $x y,{ }^{58}$ definida como o operador básico que afirma a existência de mônadas fundamentais, sendo as mônadas definidas, de um ponto de vista lógico, como objetos que não têm partes próprias, uma definição que se segue da noção metafísica de atomicidade inerente à noção de mônada. Assim se $a$ for uma mônada, não existe outro corpo que seja parte própria dele: $\neg \exists x(\mathrm{PP} x a)$.

Há também as operações mereológicas primitivas de separabilidade e de divisibilidade, ambas descrevendo logicamente as assunções mereológicas na monadologia de Leibniz. Igualdades definicionais subseqüentes definem as operações básicas do sistema de mereologia, similares aos do modelo de mereologia de fundamento e do modelo de mereologia extensional clássica (no que se refere às operações de partes próprias, complementação e disjunção e soma mereológicas).

\footnotetext{
${ }^{58}$ No artigo de Burkhardt \& Degen (1990), utiliza-se o signo $\mu$ para designar a parte própria PP.
} 
Os axiomas da estrutura mereológica da monadologia, incluem o da existência de complementação, que diz que existe um objeto que é composto de mônadas (em estado objetivo). Há um axioma de transitividade, como (P2) visto acima, e um concernente à existência de uma infinidade de mônadas (um axioma infinitário), como é requerido por qualquer forma de monadismo. Os níveis fundamentais da natureza contêm uma infinidade de mônadas, a partir das quais qualquer ser vem a existir por meio de operações mereológicas naturais, pressupondo-se que elas existam na natureza.

Há o axioma do fundamento, que regula a existência de mônadas fundamentais por meio das operações de divisibilidade, que alcançam o limite metafísico da existência de mônadas como os fundamentos da divisibilidade física. Por meio deste axioma, pode-se exprimir a condição de que a realidade tem um número finito de níveis físicos, alcançando um limite para tal divisibilidade, um limite que seria o nível metafísico (chamado por Kant algumas vezes de incondicionado e por Platão de supra-sensivel) das mônadas fundamentais, representado num conjunto de axiomas como um sistema de mereologia intensional e atomístico.

Há também axiomas que afirmam que, para todo conjunto não-vazio de entidades, exige-se uma única soma mereológica. Isso está relacionado com as intuições teológicas leibnizianas de que as mônadas compõem seres resultantes de, ou supervenientes sobre, as somas mereológicas infinitas, a partir dos simples monádicos e do fato de que não existe vazio absoluto.

Dados os sistemas de mereologia extensional clássica e o sistema intensional de Burkhardt \& Degen (1990), notamos dificuldades e limitações (a serem superadas) que são relevantes para a remodelagem do sistema de Burkhardt \& Degen, com vistas a torná-lo adequado para propor uma interpretação contemporânea da monadologia. Existem duas 
espécies de questões a serem consideradas. A primeira está relacionada com a atomicidade do sistema mereológico, isto é, com a questão de se saber se a matéria é realmente finitamente divisível, isto é, se existem níveis finitos de realidade na natureza. A segunda está relacionada com a questão de se saber se o sistema de mereologia pode ser compatível com a teoria da percepção, pois a mônada seria constituída ${ }^{59}$ por elementos mentais, que seriam as bases ontológicas para percepções, apetências e sensações.

Consideremos a questão dos níveis da realidade e divisibilidade. A intuição do axioma do fundamento indica um limite para a divisibilidade, mas de acordo com o monadismo leibniziano, e também com outros monadismos, o elemento material primário é infinitamente divisível (tal como requerido para a doutrina da infinidade atual). A par disto, as teorias físicas atuais parecem indicar que a matéria física pode ser descrita sob a forma de campos que corresponderiam, de um ponto de vista ontológico, a um plenum físico sem átomos. Portanto, podemos levantar a questão relacionada com as assunções sobre a divisibilidade no sistema de mereologia de Burkhardt \& Degen (1990): como reconciliar a divisibilidade infinita da matéria física com a existência de um limite metafísico de tal divisibilidade, qual seja, a existência de mônadas físicas fundamentais? O sistema de mereologia de Burkhardt \& Degen deixa tal questão em aberto, mas o sistema de mereologia extensional clássica pode ser estendido conservativamente de modo a fazer a

\footnotetext{
${ }^{59}$ Eu digo que a mônada é "constituída" por elementos, mas não composta, uma vez que ela é simples. No meu sentido, a composição se refere às substâncias compostas por relações de superveniência. A constituição, no sentido da moderna mereologia, eu a tomo como no sentido de Simons (2003, p. 239): "x constitui y se, e somente se, x poderia ser um substratum diante da destruição de y". Podemos interpretar "destruição" como uma divisibilidade geométrica, quantitativa ou extensional progressiva ou regressiva, ou ainda fluxo ontológico, que, seguindo Leibniz, é atualmente impossível em sentido absoluto, como se lê no §77 da Monadologia: "Assim, pode se dizer, não só a Alma (espelho de um universo indestrutível) é indestrutível, mas também o próprio animal, embora com frequência sua máquina pereça parcialmente e abandone ou tome vestimentas orgânicas" (tradução minha).
} 
atomicidade compatível com a não-atomicidade de um plenum ontológico, tal como lemos na passagem abaixo:

Entre as duas principais opções correspondentes à atomicidade e à não-atomicidade, existem, é claro, espaço para posições intermediárias. Por exemplo, pode-se sustentar que existem átomos, embora nem tudo tenha uma decomposição atômica completa, ou pode-se sustentar que existe uma geléia sem átomos [atomless gunk], embora nem tudo seja semelhante à geléia [gunky] (Varzi, 2009).

Ou seja, axiomas podem ser incluídos no modelo de mereologia extensional clássica, assumindo-se uma atomicidade fraca, que sustenta que nem tudo é composto de átomos, e também que nem tudo é constituido do que os mereologistas chamam de "geléia sem átomos" ${ }^{\$ 00}$ (atomless gunk), isto é, o plenum, um ser com partes que têm partes próprias e estas partes têm outras partes próprias e assim ad infinitum, donde tem-se o plenum ontológico. Portanto, devemos estender o sistema de Burkhardt \& Degen de modo a permitir a existência de um plenum ontológico da matéria física. Os axiomas posteriores a serem acrescentados seriam similares àqueles da mereologia extensional clássica, expressas por exemplo em Varzi (2009).

Nas palavras de Simons (1983):

O sistema SC, como qualquer outra mereologia clássica, não se pronuncia de uma forma ou outra sobre a questão da existência ou não de átomos, ou de se saber se tudo é composto de átomos. Para recapitular, um átomo é aqui entendido num sentido mereológico específico, como um indivíduo que não tem partes próprias, ou equivalentemente, como um cuja única parte é imprópria, ou seja, ele mesmo. O modelo mais simples de uma mereologia na qual existem átomos é o modelo trivial; qualquer modelo finito de SC é forçosamente atomístico e tem cardinalidade $2^{n}-1$, onde $n$ é o número de átomos [...] A união disjuntiva de um tal modelo com um modelo atomístico fornece um modelo que não é nem atomístico nem sem átomos: existem alguns átomos, mas nem tudo e composto de tais átomos (Simons, 1983, p. 41).

\footnotetext{
${ }^{60}$ Cf. Lewis (1991, p. 19) como um exemplo de importante conciliação entre a atomicidade e a nãoatomicidade da realidade, com base em sua teoria dos singletons.
} 
Tal sistema pode ser considerado consistente com as assunções leibnizianas do monadismo clássico em três pontos. Primeiro, eles são consistentes com o plenum ontológico e com as mônadas do sistema leibniziano, bem como com outras variedades de monadismo; em segundo, com a assunção da existência de um plenum ontológico da matéria física (sem a existência de mentes) e, terceiro, com a ideia da existência de mônadas (isto é, com a existência de mentes).

Agora devemos responder à questão das mentes perceptuais no sistema monadológico de mereologia. Em suporte à principal tese deste ensaio, eu formulei a tese mereológica como a afirmação de que toda coisa é uma substância composta que é composta de uma infinidade de simples. Mas o simples é um todo verdadeiro (não redutível às suas partes), cujas partes são mentais e físicas. Portanto, as partes mentais entram na composição de qualquer ser; os seres se tornam seres pensantes, que variam desde as estruturas subatômicas da física até seres humanos e criaturas mais elevadas.

Os monadistas concordam com a concepção panpsiquista de que o mental é uma parte fundamental na composição e constituição dos seres. Leibniz de alguma forma condensou tal consideração monadista nas seguintes passagens sobre as percepções:

§13. Este detalhe deve envolver a multidão na unidade do simples; pois toda mudança natural é feita em graus, alguma coisa muda e alguma coisa permanece e, como conseqüência, é necessário que na substância simples haja uma pluralidade de afecções e de relações, ainda que não haja partes.

$\S 14$. O estado passageiro que envolve e representa a multiplicidade na unidade ou na substância simples não é outra coisa senão aquela que chamamos percepção, a qual devemos distinguir da apercepção e da consciência, tal como se mostrará a seguir [...] §15. A ação de um princípio interno, que faz a mudança ou a passagem de uma percepção para outra, pode ser chamada apetição; é verdade que a apetência nem sempre ocorre em toda percepção para onde ela tenda, mas ela sempre obtém algo, e atinge novas percepções. §16. Nós experienciamos em nós mesmos uma multiplicidade na substância simples, quando achamos que o pensamento do qual nos apercebemos envolve uma variedade no objeto. Assim, aqueles que reconhecem que a alma seja uma substância simples, devem reconhecer a multiplicidade na Mônada [...] (Leibniz, [1714] 1974, p. 64). 
As passagens acima referidas estabelecem os fundamentos da teoria da percepção na monadologia e servem como bases para complementar os axiomas que faltam no sistema de mereologia Burkhardt \& Degen. Estenderíamos tal sistema, conservativamente, definido uma relação perceptual, qual seja, uma relação- $\pi$, a par da relação- $\mu$ (two-sorted model).

Correspondendo à ideia da transição da multiplicidade (de fato uma infinidade de estados internos) para a unidade, como resultado da atividade perceptual monádica, nós acrescentaríamos axiomas relativos aos estados perceptuais das mônadas. Eles poderiam ser, em primeiro lugar, a passagem de uma infinidade de estados perceptuais $\pi_{1}, \pi_{2}, \ldots$, $\pi_{\infty}$ para a Mônada (a); em segundo lugar, a transição simples de uma percepção para outra, ou seja, a apetência; e, em terceiro lugar, a percepção de outros estados perceptuais, ou consciência de mônadas mais desenvolvidas.

Estes axiomas da percepção monádica ainda não completam a articulação da premissa composicional mereologia de meu argumento. ${ }^{61}$ Existe uma importante questão a ser considerada, antes de finalizar, que é a questão de se os estados perceptuais das mônadas são completamente fechados. As mônadas leibnizianas não têm "janelas" de relações, isto é, elas são causal e eficientemente fechadas, de tal modo que não existe

\footnotetext{
${ }^{61}$ Há também uma questão adicional, pois esses axiomas representam sintaticamente algo que filosoficamente deve-se considerar fenomenologia da percepção monádica sensível, já empreendida por Husserl, de uma monadologia entendida como mudança de estados de um "autômato espiritual" - na expressão metafórica de Leibniz. No contexto das diversas interpretações do sistema leibniziano da percepção sensível, há um considerável debate a respeito do fenomenalismo de Leibniz, que consiste na tese de que são as percepções das mônadas que, no seu conjunto, criam a aparência fenomênica do mundo sensível e material que experienciamos, mundo que a metafísica procura transcender e penetrar através de uma inquirição que busca a essência.
} 
relação causal eficiente que estabeleça uma comunicação entre duas mônadas dintinguíveis. $^{62}$

Mas o fechamento perceptual traz consigo a questão lotzeana da existência objetiva da percepção inteligível das mônadas: se as mônadas são completamente fechadas e não há relação física entre elas, o que elas percebem objetivamente? Ou seja, qual é a realidade objetiva (sendo o termo "objeto" possivelmente referente ao universo inteiro de relações do mundo) de suas percepções sensiveis $?^{\mathbf{6 3}}$

Nossa resposta a esta questão deve ir em direção a um novo e mais desenvolvido conceito de mônada e de monadologia, na qual mônadas não são completamente fechadas, causal e sensivelmente. Existiria alguma abertura causal (favorável à fenomenologia da percepção sensível) nas mônadas. Conjecturo que tal abertura perceptual seria mínima nas mônadas fundamentais e se desenvolvem nas mônadas humanas e outras superiores. E as

\footnotetext{
${ }^{62}$ A questão acima é de fato intrigante, mas podemos elaborar uma interpretação do sistema leibniziano de modo a abordar a dificuldade do fechamento monádico, quando pensamos em grandes áreas do conhecimento contemporâneo, abertas pela questão intuitiva de Lotze sobre a realidade objetiva das percepções monádicas, tais como a teoria da intencionalidade de Husserl e o debate contemporâneo sobre a intencionalidade na tradição pós-analítica. Achamos aqui espaço para uma resposta leibniziana: penso que Leibniz concordaria em parte com a "abertura causal eficiente", de modo a indicar uma forma de causalidade no mundo dos fenômenos, segundo uma monadologia inteligível, mas apenas como fenômenos bem fundados da realidade sensível, indicando assim uma ontologia quase-platônica da realidade supra-sensível. Fenômenos amplamente considerados contemporaneamente pela filosofia da mente e pelas teorias biológicas evolutivas, tais como a intencionalidade dos atos e da linguagem, e a evolução das espécies, seriam fenômenos bem fundados $a$ posteriori por meio do que chamo aqui "relações composicionais de agregação de uma infinidade atual de percepções insensíveis das mônadas de fundamento", fundamentos estes que podemos chamar (metaforicamente) de sementes ou nascentes do real. Destarte, a causa eficiente amplamente vigente no mundo da experiência sensível seria apenas um fenômeno bem fundado, não incognoscível como "coisa em si" kantiana, sendo a expressão mais superficial aos olhos do mundo sensível semelhante a um "arco-íris supra-sensível" que nós, enquando sensoria commune dos cartesianos, chamamos, equivocamente para o idealista, "realidade objetiva" ou "mundo".

${ }^{63}$ Esta questão da abertura causal da "janela" monádica é fundamental para o posicionamento contemporânea do monadismo. Tal questão, anteriormente abordada por Descartes e pelos cartesianos, foi colocada primeiramente por Lotze (1885) e outros filósofos monadistas na tradição leibniziana. Em correspondência pessoal, Schneider (2009) coloca que as mônadas leibnizianas são (metaforicamente) "fechadas" causalmente apenas com relação à causalidade eficiente intermonádica. Com relação à causalidade final intermonádica, as mônadas seriam "abertas" ou teriam "janelas" abertas.
} 
mônadas podem possivelmente, mas não atualmente, perceber o universo inteiro de mônadas, porque elas percebem perspectivamente os objetos de suas percepções com maior ou menor claridade (em relação ao todo). Isso pode ser incluindo no sistema axiomático, com axiomas posteriores envolvendo um "functor de percepção" (com um contepudo intencional husserliano), que dizem que existem objetos para a percepção das mônadas, e que cada mônada pode possivelmente perceber a relação entre as partes de um determinado universo.

E devemos adicionar a universalidade das percepções inteligiveis, que é condensada nas seguintes passagens bem conhecidas de acordo com o monadismo leibniziano:

§56. Ora esta ligação ou este ajuste de todas as coisas criadas cada qual com todos, e de todos com cada um, faz cada substância simples ter relações que expressam todas as outras, e que cada qual é um espelho vivo e perpétuo do universo.

§57. E justamente como a mesma vila observada de diferentes pontos de vista parece ser inteiramente outra e multiplicada perspectivamente, assim a infinita multiplicidade das substâncias simples, que parece ser tantos universos diferentes são, entretanto, somente a perspectiva de um único universo de acordo com diferentes pontos de vista de cada mônada (Leibniz, [1714] 1974, p. 64).

A passagem acima referida, que é chamada comumente de tese do espelhamento,

pode ser melhor detalhada no trecho dos escritos diplomáticos:

O prazer, contudo, é duplicado pela reflexão, toda vez que contemplamos a beleza dentro de nós que nossa consciência faz, para não dizer da virtude. Mas a dupla refração pode ocorrer em nossa visão, uma vez na lente do olho e uma vez na lente de um tubo, o último aumentando a visão do segundo, de tal forma que exista uma dupla reflexão no pensamento. Pois toda mente é como um espelho ${ }^{64}$, e um espelho está em nossa mente e outro está na mente de outro alguém. Se há muitos espelhos, isto é, muitas mentes reconhecendo nosso bem, haverá maior luz, os espelhos misturando a luz não somente no olho, mas também dos indivíduos entre si. O esplendor reunido constitui glória (Leibniz, 1969, p. 137).

\footnotetext{
${ }^{64}$ Leibniz, em seus escritos, já afirmava: mihi videtur omne mentem omnisciam totum universum sed confuse (a mim me parece que todas as mentes refletem todo o universo, mas de forma confusa). Cf. Leibniz (1966).
} 
Adicionaríamos assim axiomas que traduzem a existência objetiva de um único universo e a possibilidade da percepção da unidade deste universo (fundamento para o pensamento cosmológico). Isso seria a base para um sistema de mereologia, adequado para a defesa da tese composicional mereológica, que difere, em alguns aspectos, do sistema proposto por Leibniz e por Burkhardt \& $\operatorname{Degen}^{65}$. A abertura perceptual em relação ao universo sensível torna possível a fundamentação de uma resposta sobre a questão da causação mental e sobre a fenomenologia da consciência sensível, que são amplamente investigadas na filosofia da neurociência contemporânea. Focalizarei, neste ensaio, a relação da tese principal do monadismo com a questão da causação mental no materialismo não-reducionista. A análise acima desenvolvida completa minha defesa da tese mereológica, isto é, da tese de acordo com a qual a relação psicofísica é uma relação composicional que se origina a partir dos seres simples. Articulo, a seguir, a premissa ontológica, que é a tese de que o simples, que entra na composição das relações mentecorpo, é uma substância fundamental.

\footnotetext{
${ }^{65}$ Introduzo aqui esta diferença em relação à metafísica de Leibniz, pensando nas objeções de Lotze (1885), na teoria da percepção, e em Husserl ([1931] 1988), na teoria da mônada-ego e da intersubjetividade, ao isolamento monádico leibniziano, objeções que me parecem situar o monadismo no debate contemporâneo sobre as relações mente-corpo.
} 


\section{Capítulo III \\ A Tese Ontológica das Relações Psicofísicas}

Nos capítulos anteriores, esbocei algumas noções de condições das teses composicionais em apoio à tese principal do monadismo. Com relação à tese holística composicional, nós consideramos as condições logicas para o holismo composicional, variedade de holismo que se refere à questão, amplamente tida no campo da ontologia de objetos, de como as partes perfazem um todo. Com relação à tese composicional mereológica, este todo é, de acordo com certas condições, um simples que entra na composição dos seres compostos.

\section{1 - A Substância Simples ou Mônada}

Nesta seção, é necessário defender a premissa ontológica de meu argumento em favor do monadismo, uma premissa que chamo de tese ontológica, na qual a noção primordial é a de "substância", que figura nas grandes áreas da metafísica da permanência e da subsistência dos seres, sejam estes simples ou compostos. Aqui, prossigo oferecendo um argumento para o monadismo ou substancialismo, por meio do esboço do aspecto ontológico dos todos simples substanciais e dos compostos a partir desses simples.

Há dois pontos de vista relevantes: o holístico e o mereológico. O primeiro, em relação ao senso comum, concerne ao simples, considerado como um todo relativamente constituído de partes elementares, ao passo que o segundo concerne à substância simples para composição de substâncias compostas. Temos que também definir a questão 
ontológica da existência e, portanto, analisar ontologicamente as existências simples e composta das monâdas fundamentais.

O debate mente/corpo contemporâneo tem discutido como o mental se relaciona com a matéria física. Muitas respostas têm sido fundamentadas em variedades de "monismo" e de "dualismo", e mesmo de "pluralismo". Todas estas variedades pressupõem uma questão que tem sido ignorada por muitos: o que é a substância, que se enumera solo numero, que fundamenta as relações entre o mental e o físico? A questão conseqüente que naturalmente se coloca aqui é como o mental e a matéria física, que são considerados como relações de parte-todo, constituem o simples substancial. Esta tem sido, em minha opinião, uma questão ignorada no debate contemporâneo sobre o problema mente-corpo (mas não ignorada nas discussões lógicas contemporâneas sobre o holismo e a mereologia). Ao estabelecer a premissa da composicionalidade, argumento pressupondo a reconsideração da questão do que seja a substância, com vistas a esclarecer o problema mente-corpo por meio da resposta à questão ignorada: o que é substância? Ou, doutra forma: o que permanece sob os fenômenos da mudança? Por meio do pressuposto da relevância desta questão, penso que seja possível compreender melhor as relações mente-corpo.

Como resposta a esta difícil questão, podemos começar dizendo que a "coisa", que é também denominada "fundamento subsistente e permanente de toda mudança fenomênica sensível”, é chamada, em metafísica, de substância simples, ou simples. Como é bem sabido:

A ideia-raiz por trás do conceito de substância parece ser que, contrariamente às aparências, as coisas que constituem o mundo em mudança que nos rodeia são na realidade compostos por, ou de alguma forma resultante de, poucas espécies de entidades relativamente permanentes ou estofo [stuff], e que seus atributos podem ser explicados e preditos como de alguma forma dependendo de atributos de materiais mais básicos. Em particular, as mudanças observadas nos objetos cotidianos, incluindo a origem e destruição deles, devem 
ser explicadas como resultante de mudanças em, ou recombinação de, ingredientes subjacentes, assumindo que estes, mudando eles mesmos ou não, retêm sua identidade através de tais episódios (Mates, 1994, p.189).

Portanto, de acordo com a passagem a que nos referimos acima, a substância é o fundamento metafísico dos fenômenos, uma espécie de estofo que "reside sob" eles. Respostas diferentes têm sido propostas pelos filósofos contemporâneos com relação ao que seria a coisa subsistente, fundamento de tudo que está mudando no mundo. No caso do monadismo, podemos mencionar a mônada leibniziana como uma noção clássica mencionável sobre a substância. A teoria leibniziana envolve muitas concepções sobre as substâncias que são relevantes para o monadismo contemporâneo. Desse modo, as seguintes características da substância são relevantes: (a) Existência do sujeito último de toda predicação, de acordo com a doutrina do conceito completo. (b) Atividade, isto é, a substância é a fonte primária de atividade para toda e qualquer mudança. (c) Persistência, as substâncias persistem sob a mudança, permanecendo as mesmas. (d) Unidade per se (totalidade holística), como oposto a unidade acidental (totalidade mereológica). (e) Individuação: a substância é o princípio que faz uma entidade ser individuada, no sentido de ser um princípio individual de ação. (f) As substâncias estão prenhes com seu futuro. (g) As substâncias exprimem o universo inteiro ${ }^{\mathbf{6}}$.

As características da substância em Leibniz são também contrastáveis com a noção cartesiana de substancialidade das coisas. Como é bem sabido, as noções de substância em Descartes e em Spinoza são fundamentadas na noção de res extensa, pressupondo o que se pode chamar de uma concepção extensiva da substância. Esta concepção é oposta à

\footnotetext{
${ }^{66}$ Tais características da substância em Leibniz são apontadas por Rutherford (1995, pp. 133-7).
} 
concepção intensiva (intensive) de substância, tal como um intérprete de Leibniz argumentou nesta passagem:

Quando aplicamos rigorosamente o princípio de que a realidade da substância é o que permanece depois da remoção de todas as qualidades diferenciais específicas, não deixamos nada senão quantidade - também, como no caso de Spinoza, quantidade de substância em geral; ou, como em Descartes, quantidade de uma substância específica, que quer dizer quantidade de uma qualidade. Assim a posição de Descartes é que em adição à verdadeira $\mathrm{e}$ perfeita substância, Deus, cuja existência é externamente incondicionada, existem duas outras substâncias criadas, cuja existência não é condicionada por algo finito, mas somente pela substância infinita. Existem a substância corporal e a substância pensante [...] Todas as qualidades específicas das coisas criadas são redutíveis a uma ou outra destas, como uma qualidade comum; e, consequentemente, a essência ou realidade da substância criada se torna ou extensão sem conteúdos específicos, ou pensamento sem objeto específico. Em outras palavras, a substância corporal é quantidade de uma determinação, isto é, extensional; enquanto que a substância pensante é quantidade de uma outra determinação, isto é, pensamentos. Assim, o pressuposto do sistema cartesiano é a relação puramente quantitativa de todo e partes (Latta, 1898, p. 26).

Concordamos com a interpretação de Latta, de que a pressuposição intensiva é oposta à pressuposição extensional de substância. Tal oposição parecer ser assumida por

Leibniz, como lemos na passagem seguinte:

De acordo, a essência do argumento de Leibniz é que uma concepção quantitativa de relação de todo e partes dá suporte a uma teoria inadequada de substância. O elemento comum nas posições contrárias dos cartesianos e dos atomistas é a redução, implícita ou explícita, de diferença qualitativa à quantitativa. E parece a Leibniz que a solução do dilema deve ser encontrada na hipótese oposta, isto é, que a essência da substância é nãoquantitativa e que a relação entre todo e partes deve ser concebida como intensiva [intensive], em vez de extensiva. Assim, uma "substância simples" não tem partes, isto é, é sem elementos quantitativos que ainda devem incluir uma variedade em uma unidade; isto quer dizer, esta deve ser real, dever ser algo, deve ser qualitativa, especificamente determinada (Latta, 1898, p. 27).

Além de ser considerada como intensiva, investiguemos a substância leibniziana no principal argumento composicional ontológico proposto pelos monadistas, que é expresso 
de forma simples pelo monadismo clássico nos célebres parágrafos que introduzem a noção de mônada e sua imortalidade, segundo o sistema de Leibniz:

§1 - A Mônada, a qual discutiremos aqui, não é nada senão uma substância simples que entra nos compostos - simples, quer dizer sem partes.

$\S 2$ - E deve haver substâncias simples, posto que há compostos; pois o composto nada mais é do que a coleção, ou agregado, dos simples.

§3 - Ora, na Mônada, não há partes, nem extensão, nem forma, nem divisibilidade possível; estas mônadas são os verdadeiros átomos da natureza, em suma, os elementos das coisas.

$\S 4$ - Delas também não há a temer qualquer dissolução: é inconcebível que uma substância simples possa perecer naturalmente (Leibniz, [1714] 1974, p. 63).

De acordo com as passagens clássicas acima descritas, as substâncias leibnizianas, os simples, ou "os verdadeiros átomos da natureza", ou os "átomos pontuais metafísicos", são as partes que entram mereologicamente nas substâncias compostas.

Nós concordamos com as características fundamentais da substância estabelecidas por Leibniz, que resumiu as noções de mônada propostas por outros monadistas, como as de Giordano Bruno, sendo que tais noções foram posteriormente, em direção ao mundo pós-moderno, desenvolvidas por monadistas como Lotze e Husserl (ao fundar a fenomenologia transcendental). Eles ainda são adequados para o monadismo não-clássico ou contemporâneo, e para questionar, responder e dialogar em meio ao debate contemporâneo na filosofia da mente.

Contudo, há uma característica fundamental adicional, esboçada por mim na premissa composicional: as mônadas estariam causal e eficientemente relacionadas umas com as outras, ou seja, existiriam janelas causais da percepção sensível por meio das quais uma mônada se relaciona com a outra. Esta característica torna nossa concepção de mônada um pouco diferente da proposta por Leibniz, porque nós discordamos da seguinte tese, a 
tese de isolamento causal sensível da monadologia leibniziana, de certo modo compensada pela doutrina da harmonia divina pré-estabelecida das substâncias monádicas:

$\S 7$ - Não existe maneira de explicar como uma mônada possa ser alterada ou mudada em seu interior por meio de outra criatura qualquer, pois podemos não saber como transpor, nem conceber na Mônada qualquer movimento interno que possa ser excitado, dirigido, acrescido ou decrescido internamente, como é possível nos compostos onde exista mudança nas partes. As Mônadas não têm janelas através das quais algo possa entrar ou sair. Os acidentes não poderiam sair ou entrar dentro das substâncias como é feito pelas espécies sensíveis dos Escolásticos. Assim, nem a substância, nem o acidente podem, provindo de fora, entrar numa Mônada (Leibniz, [1714] 1974, p. 63).

A troca de qualidade - o influxus physicus das espécies sensíveis dos Escolásticos é considerada como a única forma pela qual as mônadas poderiam mudar por meio de causas eficientes externas. Mas existem outras formas de relações entre as mônadas, que podem ser concebidas para mudança de seus estados internos. Pode haver conexões causais entre as mônadas, ou como phaenomena bene fundata ou como progressus e transmutatio, concordando com a fenomenologia de causas eficientes supervenientes às relações intermonádicas infinitárias. Semelhante abertura é considerada existente por filósofos como Bruno, Kant e Husserl.

$\mathrm{Na}$ tradição desses monadistas, pode-se perfeitamente conceber as mônadas em relação causal no mundo sensível, assumindo-se que elas sejam relações de harmonia, segundo a ordem física, expressáveis em leis intermonádicas. Esta concepção de abertura causal eficiente de uma mônada ou substância simples parece-me mais adequada para o pensamento contemporâneo e para a linha de pensamento dos monadistas que lançaram as bases do monadismo contemporâneo.

Tal como defino o termo "mônada", o estado interno das mônadas progride para uma finalidade em si (entelequias que mudam, tendem, aumentam, etc.), uma certa 
"abertura de relações causais" por meio de relações causais intermonádicas eficientes (isto seria semelhante ao que Leibniz chamaria de "transmutação" de uma mônada ou Espírito). Neste ponto, discordamos em parte da solução da interação intermonádica fundamentada somente na teoria da harmonia pré-estabelecida com fechamento monádico sensível. ${ }^{\mathbf{6 7}}$

Uma vez que definimos a teoria ontológica relacionada com as diferentes concepções sobre a substância, é possível reconsiderar o sistema de Burkhardt \& Degen para a mereologia, o que inclui uma clarificação parcial lógica ou semi-formalização da teoria da substância (adequada ao pensamento analítico contemporâneo) de acordo com os axiomas sobre a substancialidade, com vistas a definir a noção de mônada que deve divergir, de um ponto de vista histórico-filosófico, da noção clássica proposta por Leibniz em vista do porvir presenciado pela nossa era.

\section{3 - As Substâncias Compostas}

Além da relação de parte própria, existem as operações de divisibilidade ou de indivisibilidade da substância composta em substâncias simples, e de separabilidade ou inseparabilidade das partes nos todos substanciais. Com essas definições, Burkhardt \& Degen (1990) definem os axiomas de substancialidade dos simples.

\footnotetext{
${ }^{67}$ É importante salientar que Leibniz considerava que as mônadas pudessem estar em relação causal umas com as outras (relação inter-monádica). Mas esta relação causal, segundo argumentou Schneider (2009) e outros intérpretes da filosofia de Leibniz, seria de natureza final e não eficiente. Assim, as mônadas estariam em relação causal mas somente na esfera inteligível reguladas em suas interrelações pela omnipresença duma Monas Monadum bruniana ou Deus, e não no mundo sensível. Kant, em sua teoria da coisa em si, concordou em parte com a linha de pensamento leibniziana.
} 
Aqui existe lugar para relacionar a tese ontológica com a premissa composicional mereológica e com a premissa composicional holística definidas nas seções anteriores. $\mathrm{O}$ sistema de Burkhardt \& Degen de mereologia parte da noção de totalidade, para o qual são propostas as definições dos constituintes fundamentais das coisas, que são os simples ou substâncias simples, noção que é expressa segundo todos de três espécies: todo essencial, todo agregado e todo misturado ou integral (que combina os todos essencial e agregado), de acordo com a dependência de partes e todo. No caso dos agregados monádicos, as partes determinam a existência do todo (tese do essencialismo mereológico), que se torna um todo mereológico ou agregado a partir de mônadas.

O caso do "todo essencial" é especialmente interessante para a relação entre as premissas holística e mereológica do argumento para o monadismo. Porque existem as situações em que o todo determina as propriedades de suas partes, e este é o caso das substâncias. ${ }^{68}$ Neste sentido, as partes de um todo essencial seriam inseparáveis por decomposição destrutiva sensível. A espécie de totalidade, que é parte das definições do sistema mereológico intensional, semi-atomístico e infinitário de Burkhardt \& Degen, é particularmente interessante para o caso de substâncias psicofísicas.

Se se considera, junto com a tradição aristotélica, que a forma e a matéria são partes que constituem o todo essencial, então tem-se a mônada. Uma vez que são dadas definições básicas de substância, a totalidade essencial S, no sentido desenvolvido segundo a tese composicional holística, é redefinida aqui por um dos axiomas $\left(\mathrm{G}_{2}\right)$ do sistema de Burkhardt \& Degen (1990).

\footnotetext{
${ }^{68}$ Esta ideia está enraizada na tradição platônica, como se vê na seguinte passagem do Teeteto (203e): “Talvez devêssemos argumentar que uma sílaba não seja composta de letras, mas melhor dizendo, uma entidade singular estruturada além delas, distinta dessas letras, tendo sua própria forma singular".
} 
Além disso, proponho outras definições que são as operações fundamentais do sistema de monadologia que devem ser intensionais, e tais operações são assim porque são relacionadas com a noção de partes essencial e não-essencial das substâncias, de acordo com o essencialismo modal proessuposto. No sistema de definições do sistema de mereologia intensional que proponho, existe uma definição de mônada como um objeto sem partes próprias, o qual é a consideração definicional mais básica sobre a mônada, definida como um simples de toda e qualquer composição ontológica a partir de mônadas.

As ideias para uma formalização, esboçadas acima, completam minha defesa da tese ontológica em apoio a tese principal do monadismo contemporâneo. Doravante, argumentarei em favor da tese principal e também salientarei a relação da tese principal do argumento com o debate contemporâneo sobre o problema mente-corpo. 


\section{Capítulo IV}

\section{A Tese Principal, o Monadismo e o Fisicismo}

Neste capítulo, propõe-se argumentar em favor da tese principal do argumento, com relação às posições contemporâneas sobre o problema mente-corpo. As posições são, como vimos: teoria de superveniência, teoria da emergência e realismo mental. Ademais, eu gostaria de discutir doutrinas que são semelhantes ao monadismo desenvolvido neste ensaio, mas diferem em alguns pontos, doutrinas que chamo "monadismos clássicos", que aqui são as teorias de Leibniz e de Whitehead. Existem outras variedades de monadismo que seriam relevantes para consideração da relação mente-corpo neste ensaio, mas me restrinjo às doutrinas mencionadas na medida em que elas são fundamentais para a interpretação contemporânea da noção de mônada.

Começo definindo a doutrina das relações entre a mente, o corpo e o mundo. A relação monádica é a base da imagem ontológica que pode explicar a relação psicofísica. Esboçarei a tese principal que considero seguir-se das premissas explicadas nos capítulos anteriores e, em seguida, levantarei minhas objeções contra o fisicismo não-reducionista, já criticado nos capítulos anteriores. 


\section{1 - Posição da Tese do Monadismo}

Como tese principal do argumento que desenvolvo neste trabalho, ao responder à questão da relação mente-corpo e como eles se relacionam, sugiro que a mente e a matéria física se relacionam um com o outro como elementos compondo e constituindo compostos, todos unificados enquanto substâncias psicofísicas - chamadas mônadas - que compõem mereologicamente os corpos via superveniência mereológica.

$\mathrm{Na}$ avaliação do materialismo fisicista esboçada no primeiro capítulo, pode-se assumir que a noção básica a ser definida é noção de "relação". Portanto, entendo que, com vistas defender a tese principal, seria adequado começar com a definição de uma relação.

Sob a assunção de dualismo elementar, juntamente com as premissas de composicionalidade holística e mereológica e com a noção de substância simples, é possível propor uma teoria monadológica, ou monadologia, cuja relação básica envolve uma infinidade de entidades, uma relação que é infinitária. Cada par de mônadas i,j teria uma relação $R_{i j}$, e a reunião de toda essa infinidade de relações parciais constituiria a relação monádica infinitária universal $\mathrm{R}$.

Os compostos são gerados a partir da composição e decomposição mereológicas (sejam elas naturais ou artificiais) de alguns ou de uma infinidade de relata simples. Tais compostos resultariam nas percepções instanciadas ou realizadas multiplamente de alguma mônada, na hierarquia de níveis de realidade percebidos por cada mônada, como uma classe finita de relações finitas para cada mônada, constituindo mundos possíveis perceptíveis ou pontos de vista que emergem das percepções da realidade (entendida aqui como um universo de relações). 
A ideia deste ensaio é tratar da questão da relação mente-corpo a partir do dualismo elementar que constitui cada mônada, e da composição destes simples em compostos. A visão que proponho pode ser articulada a partir de três premissas, que são semelhantes àquelas da superveniência mínima e da teoria da emergência no materialismo contemporâneo:

(L1) Assunção de Dualismo Elementar: As substâncias simples são constituídas de elementos, isto é, mente $\mathrm{M}$ e a matéria física $\mathrm{P}$, sendo tais elementos entendidos como partes constitutivas de um todo, a substância simples.

(L2) Tese Ontológica Psicofísica: Tudo que existe é composto de unidades substanciais simples chamadas mônadas.

(L3) Tese de Superveniência Psicofísica: Tudo é composto por, ou sobrevém mereologicamente a, uma agregação substancial relacional infinitária, expressa como composição mereológica de mônadas.

Com base nas teses acima asseridas e explicadas nos capítulos anteriores, eu discutirei agora um pouco mais sobre os posicionamentos do fisicismo não-reducionista e sua relação com a tese principal do monadismo. 


\section{2 - Monadismo e Fisicismo: Similaridades e Divergências}

Reconsidero e examino aqui as dificuldades das teorias da superveniência, da emergência e da causação mental explicadas no primeiro capítulo, mostrando que não encontraremos essas dificuldades se assumirmos a tese do monadismo, isto é, a tese de que o mental e o físico são relacionados um com o outro como elementos de mônadas simples que compõem os seres pensantes.

Tal como expliquei a partir dos argumentos fundamentais de superveniência, existem algumas dificuldades cruciais e muito debatidas para o enfoque de superveniência da formulação e solução do problema mente-corpo.

Primeiramente, existe a dificuldade com a formulação do problema, formulação esta que é fundamentada na relação de superveniência. Argumentou-se, no debate, que esta relação seria fraca ontologicamente para defender teses materialistas. Não obstante a persuasão dos argumentos propostos em favor da tese de superveniência, a relação de superveniência permaneceu exigindo explicação adequada.

Em segundo lugar, se a relação de superveniência for em si mesma explicada, assim se fará por meio de alguma teoria funcionalista da mente (em conjunção lógica com a ontologia materialista); mas a teoria funcionalista-materialista tem sido criticada de muitas formas durante o debate contemporâneo sobre a questão da relação mente-corpo na tradição analítica.

Três linhas de argumento bem conhecidas contra a visão funcionalista tem sido relevantes no debate sobre as relações mente-corpo: primeiramente, a diferença entre as propriedades funcionais de segunda ordem e as propriedades mentais (conforme mostramos no primeiro capítulo); em segundo lugar, as objeções envolvendo a noção de qualia e, em 
terceiro, as inexplicabilidade materialista do aspecto fenomenológico da mente (os quais não consideramos ainda sob a perspectiva do monadismo). Todas estas dificuldades têm, a meu ver, um fundamento ou pressuposto comum: o importe ontológico insuficiente da mente física em meio ao universo físico e a assunção tácita da tese da primazia do físico sobre o mental.

Entretanto, de acordo com a visão monadista ou substancialista que advogo neste trabalho, estas dificuldades segue-se simplesmente da negação da assunção de que a mente tenha importe ou importância ontológica suficiente na explicação da relação mente-corpo, que se segue da tese da primazia. De acordo com o dualismo elementar (e também com o panpsiquismo), o mental é elementar para a explicação da relação psicofísica ${ }^{\mathbf{6 9}}$. Se o aspecto fundamental da mente é pressuposto, então não se teria questão com a realidade causal da mente, tal como ocorre no fisicismo não-reducionista. $\mathrm{O}$ problema fenomenológico do funcionalismo como premissa da teoria de superveniência não existe no monadismo, porque a mônada fundamental está bem no início da experiência fenomenológica, que evolui do nível mais simples até os altos níveis de consciência das mônadas humanas e mais elevadas.

Vamos agora rever as questões da instabilidade ontológica e da realidade causal da mente no emergentismo. A primeira questão se relaciona com a instabilidade do atual fisicismo não-reducionista. O segundo se refere ao irrealismo mental ou epifenomenalismo que parece ser implicado pelos argumentos em favor do emergentismo. De acordo com o

\footnotetext{
${ }^{69}$ Esta crítica ao materialismo contemporâneo na tradição analítica não atinge o dualismo naturalista de Chalmers, o qual pressupõe o importe ontológico da propriedade protofenomênica. Ademais, em correspondência pessoal, Chalmers propôs que seu dualismo naturalista seria compatível com meu dualismo elementar monadista. Tal proposta depende, obviamente, da comparação das definições, argumentos e teses em cada posicionamento sobre a explicação da relação mente-corpo, comparação esta que pretendo desenvolver em artigos.
} 
monadismo, as propriedades de base dos níveis de realidade já possuem propriedades mentais que fazem com que os todos supervenientes e emergentes tenham mentalidade. Portanto, o monadismo bloqueia a instabilidade do fisicismo não-reducionista por assumir que a mentalidade está nas condições basais (o que é exigido pelo dualismo elementar). As partes de um todo emergente já possuem pré-mentalidade, de tal modo que o todo em questão (o todo psicofísico) sempre tem algum grau de mentalidade nos níveis diferentes da natureza $^{70}$

Como uma terceira consequência do monadismo, é possível oferecer o que propomos ser um argumento para a inclusão causal do mental, o qual oponho à consequência do epifenomenalismo resultante do debate em torno da emergência. Meu argumento para inclusão, que parte de princípios fundamentais do monadismo coligidos por Leibniz em suas definições analíticas, envolve as seguintes teses:

(M1) Harmonia Estabelecida (Nomologia): P é relacionado a P* por comunicação, então M é relacionado, por comunicação, a $M^{*}$;

(M2) Relação Causal Substantiva: Causas e efeitos estão entre si como entre forma e matéria de uma substância simples, a mônada.

(M3) Relação Causal Metafísica: P é relacionado a P* no nível do plenum, então, tudo causa possivelmente, mas não atualmente, $\mathrm{P}^{*}$

(M4) Tese de Atualização, Realização ou Especificação Múltipla: M é instanciado, realizado ou especificado causalmente em meio aos seus realizadores físicos. ou atuais sincrônicos Ps, via uma infinidade atual de formas.

\footnotetext{
${ }^{70}$ Esta possibilidade, segundo a qual as partes de um todo emergente têm propriedades do todo emergente, não é excluída pelos emergentistas. Cf. Kim (1999, pp. 29-31) para a análise da causação descendente reflexiva.
} 
(M5) Tese da Inclusão Causal: M é possivelmente incluído na rede causal ligando Ms e Ps.

Posso agora comparar o fisicismo com o monadismo indicando similaridades e divergências. Primeiramente, o monadismo concorda que o universo tem um fundamento ontológico, mas nega que tal fundamento seja composto de partículas de matéria; tal fundamento é composto de substâncias simples. O monadismo concorda que tais fundamentos estão na base para superveniência e tudo o mais, porém, por outro lado, discorda da ideia da tese de primazia, isto é, da ideia de que o físico ou matéria física seja a única base subveniente. Existem relações causais conectando entidades, estado e eventos mas, por outro lado, discorda com a assunção de que tais relações sejam apenas objetivas e determinísticas; a causação conectando as substâncias simples, sob a assunção do dualismo elementar, implicam relações poliádicas e sobredeterminadas (conforme argumentamos na seção I.5) que, de acordo com a definição contemporaneamente interpretada de mônada ${ }^{\mathbf{7 1}}$, têm um ponto de vista do mental, que é ativo, protofenomênico e subjetivo ${ }^{72}$.

Estas considerações representam a avaliação da interpretação da causação que fundamenta grande parte do argumento em favor da superveniência. $\mathrm{O}$ dualismo elementar permite a inclusão causal da mente, como oposto à interpretação fisicista da causalidade psicofísica, que excluiu o mental do universo físico.

\footnotetext{
${ }^{71}$ Cf. Leibniz ([1714] 1974), uma teoria que é compartilhada por Nagel (1986) e por Chalmers (1996).

${ }^{72}$ A mônada é a unidade orgânica, e tal unidade é precípua de uma filosofia que é fundada na noção de organismo. Esta direção foi desenvolvida por Whitehead em sua concepção de mônada, tal como mostrarei mais adiante. Cf. Whitehead ([1929] 1985, cap. 2, seção VI, p. 80).
} 
Como resultado da discussão de algumas questões específicas nas doutrinas da superveniência, da emergência e da causação mental, eu sugeriria que o dualismo elementar é uma espécie de inferência para melhor explicação, por colocar a mente no mundo natural e por oferecer uma estrutura possível para formulação e solução do problema mente-corpo. O dualismo elementar pode, pelo menos, evitar as dificuldades cruciais do fisicismo.

\section{3 - Monadismos Clássicos de Leibniz e de Whitehead}

O monadismo não é uma doutrina nova. É bem sabido que na filosofia antiga podem-se encontrar alusões e conceitualizações sobre as mônadas nas tradições egípciohermética, grega e judaica-cabalista.

Com relação à concepção moderna, podemos encontrar filósofos como Giordano Bruno, Gottfried Leibniz, Étienne Condillac, Immanuel Kant, Johann Herbart, Hermann Lotze, bem como outros filósofos, que utilizaram o conceito de mônada para tratar muitas questões filosóficas, principalmente aquelas da filosofia da mente. Nesta seção saliento algumas diferenças entre a noção de mônada desenvolvida contemporaneamente e aquela que pode ser incluída nos monadismo modernos passados.

Consideremos aqui dois filósofos para ilustrar a conceito moderno de mônada como resposta à questão da relação mente-corpo. São eles o célebre Leibniz e o matemático Alfred North Whitehead. Ambos são mencionados como notáveis monadistas que investigaram aos fundamentos metafísicos das ciências. Apresentarei pressupostos, teses e argumentos primeiramente relativos às mônadas leibnizianas e, em segundo lugar, às mônadas whiteheadianas, que são por Whitehead denominadas "entidades atuais". 
Destacarei, também, as semelhanças e diferenças entre esses sistemas de monadologia clássica e o que poderia ser chamado de monadologia contemporânea.

\section{1 - Leibniz}

A monadologia de Leibniz é o mais importante sistema de pensamento monadológico, estando fundamentada na noção de substância. Sua fonte clássica de princípios monadológicos é a síntese de muitas ideias que monadistas anteriores definiram como características da noção de mônada. Com vistas a ilustrar as concepções fundamentais sobre a monadologia, saliento os argumentos críticos da filosofia da mente de Leibniz se referindo às mônadas como fundamentando três tópicos: centros de percepções sensoriais imperceptíveis na psicologia (que poderíamos chamar contemporaneamente de inconsciente), princípios diferenciais do movimento na física (calculus infinitesimalis) e a lei dos indiscerníveis na metafísica. Ao longo desta seção, examinarei as semelhanças e diferenças entre o monadismo clássico e contemporâneo relativamente a estes três tópicos.

Pode-se começar investigando a seguinte passagem explicativa da noção de percepção insensível:

É também pelas percepções insensíveis que se explica esta admirável harmonia préestabelecida da alma e do corpo, e mesmo de todas as Mônadas ou substâncias simples - de tal forma que sua alma se harmoniza não só com seu corpo, mas também com toda outra mônada do universo. Esta harmonia nos salva na visão insustentável de que substâncias simples se influenciam umas às outros, substituindo influência por mera correlação. Na opinião de Bayle, autor do mais belo dos dicionários, minha doutrina da harmonia enaltece a grandeza da perfeição divina além de tudo o que se tenha jamais concebido. São essas pequenas percepções que nos determinam em muitas ocasiões sem que pensemos, e que enganam o homem vulgar a pensar que não há nada atuando em nós, quendo nos inclinamos 
em um sentido ou outro, como se fosse para nós completamente indiferente (para dar um exemplo) voltarmos à direita ou à esquerda. Elas produzem em nós essa inquietação, que demonstrarei consistir em algo que difere da dor apenas como o pequeno difere do grande, inquietação que constitui muitas vezes o nosso desejo ou mesmo o nosso prazer, dando a estes, por assim dizer, um tempero picante. São também estas partes insensíveis das nossas percepções das cores, dos calores e outras qualidades sensíveis, e entre os movimentos nos corpos que lhes correspondem, ao passo que os cartesianos (e também Locke, por mais penetrante que seja) concebem as percepções que temos dessas qualidades como arbitrárias, ou seja, com se Deus as tivesse dado à alma [...] Devo dizer que esta opinião me surpreende e me parece pouco digna da sabedoria do Autor das coisas, que nada faz sem harmonia e sem razão (Leibniz, [1704] 1996, Prefácio, p. 7).

As mônadas e suas percepções insensíveis, acima detalhadamente descritas segundo os qualia e raw feels contemporâneos, são os fundamentos das noções modernas da fenomenologia das percepções sensíveis, e certamente indicam a noção de inconsciente da psicologia contemporânea. Existe uma diferença crucial entre as mônadas clássicas e a concepção contemporânea aqui proposta: enquanto Leibniz fundamenta as correlações psicofísicas ultimamente na sabedoria de Deus, o monadismo contemporâneo fundamentaria tal correlação (mesmo sobre relações causais metafísicas) em leis causais naturais psicofísicas, tal como é argumentado por muitos filósofos da mente contemporâneos.

Outra passagem segue-se à anterior e se refere à relevância das substâncias simples ou mônadas para a psicologia e para a teoria do movimento dos corpos:

Em uma palavra, as percepções insensíveis são de uso tão vasto na pneumática quanto os corpúsculos insensíveis o são na ciência natural, sendo igualmente irracional rejeitar uns e outros, sob o pretexto de que estão fora do alcance dos nossos sentidos. Nada se faz de repente, e uma das minhas grandes máximas, e das mais comprovadas, é que a natureza nunca faz saltos: o que eu denominei Lei da Continuidade, quando dela falei nas primeiras Notícas da República das Letras. O uso dessa lei é muito considerável na física; ela significa que se passa sempre do pequeno ao grande, e vice-versa, através do médio, tanto nos degraus como nas partes, e que jamais um movimento nasce imediatamente do repouso nem se reduz, a não ser por um movimento menor, assim como não se chega jamais a percorrer nenhuma linha ou comprimento antes de ter antes percorrido uma linha menor, se bem que até agora os que elaboraram as leis do movimento não tenham observado esta lei, acreditando que um corpo possa receber em um instante um movimento contrário ao 
precedente. Tudo isto mostra mais uma vez que as percepções grandes e notáveis provêm por graus daquelas que são excessivamente insignificantes para serem notadas. Não concordar com isto equivale a conhecer pouco a imensa sutilidade das coisas, que envolve um infinito atual, em toda parte e sempre (Leibniz, [1704] 1996, Prefácio, p. 7).

A passagem dereve uma das doutrinas mais notáveis de Leibniz, isto é, a doutrina da continuidade e das infinidades atuais como aspectos da realidade. Pode-se notar que estas doutrinas foram relevantes para o desenvolvimento das ciências modernas. Assim, ambas doutrinas foram cruciais para o desenvolvimento do monadismo clássico e foram referenciais para a origem da doutrina contemporânea de mente, que inclui a versão contemporânea do monadismo.

Como uma comparação entre os monadismos moderno e contemporâneo, pode-se destacar a passagem sobre a lei da indiscernibilidade de Leibniz, que tem sido muito citado na filosofia da mente:

Eu tenho também salientado uma conseqüência das variações imperceptíveis, isto é, que não há dois indivíduos perfeitamente iguais. Duas coisas quaisquer devem diferir mais do que numericamente. Isto coloca um fim em: a alma como uma página vazia; uma alma sem pensamento; uma substância sem ação; espaço vazio; átomos; repouso absoluto; partes completamente uniformes do tempo, da posição, ou da matéria, e centenas de outras ficções que tem surgido da incompletude das noções dos filósofos. (Eu acrescentaria esta: em se rejeitando átomos, implica-se que toda porção de matéria poderia ser dividida. Minha tese sobre diferenças implica algo mais forte, isto é, que toda porção de matéria é atualmente divisível.) (Leibniz, [1704] 1996, Prefácio, p. 7)

Na afirmação descrita acima, a crítica de Leibniz parece ser situável no pensamento contemporâneo, mas ela ainda não foi explorada em todas as suas conseqüências. Algo importante é a diferença, a qual é enfatizada por Leibniz, entre o abstrato e o concreto e também entre realidade e ficção metafísicas. No monadismo clássico, as mônadas são relativas à realidade das coisas, enquanto que várias outras entidades, tais como aquelas que se encontram na matemática, são meras ficções hipotéticas sobre o que seja real. As 
mônadas, sejam elas classicamente ou contemporaneamente concebidas, dão a substância das coisas. Então, ideias como repouso absoluto, espaços vazios, coisas perfeitamente semelhantes, etc. são, na doutrina de Leibniz, apenas ficções (hipóteses), não obstante úteis que sejam nas ciências especiais.

Outra passagem alude à doutrina clássica das mônadas. Esta é relacionada com o princípio de identidade ou, seu inverso, o princípio de alteridade, ambos resultantes do princípio de individuação. A identidade ou a diferença não pode ser baseada na estrutura espaço-temporal somente, de acordo com a doutrina de Leibniz das denominações extrínsecas (estrutura) como opostas às denominações intrísecas (mônadas):

A mera organização ou estrutura sem uma força-vida permanente que eu chamo de mônada não seria suficiente para fazer algo permanecer o mesmo indivíduo. Porque a estrutura pode continuar especificamente sem continuar individualmente, isto é, o padrão pode continuar, mas se tornar um padrão de uma matéria diferente [...] Assim nós devemos reconhecer que os corpos orgânicos, bem como os inorgânicos, permanecem "os mesmos" somente na aparência, e não estritamente falando. Isto é muito semelhante a um rio cuja água está mudando continuamente ou ao navio de Teseu no qual os atenienses estavam constantemente fazendo reparos. Mas assim para as substâncias que possuem em si mesmas uma unidade real, genuína e substancial, substâncias que são capazes de ações que podem propriamente ser chamadas "vitais" e seres substanciais que são animados por um certo espírito indivisível, pode-se corretamente dizer que eles permanecem perfeitamente o mesmo indivíduo em virtude desta alma ou espírito que constitui o "eu" nas substâncias que pensam (Leibniz, [1704] 1996, II, xxvii, p. 108).

Portanto o princípio de individuação não pode ser ligado às denominações extrínsecas que estão sempre mudando, tal como argumenta Leibniz. Melhor, a mônada é a fonte da individuação e, no parágrafo acima referido, a mônada é comparada com a alma ou espírito, como fundamento para identidade pessoal. Nós podemos pensar que esta ideia possa permanecer a mesma no caso do monadismo interpretado contemporaneamente, mas isto permanece problemático no caso da prova da tese da imortalidade da alma, uma tese com a qual Leibniz concordou e incluiu em seu sistema filosófico. 
Argumentando em favor da tese de que a matéria não pode ser o ser supremo primeiro, Leibniz afirma:

Eu pronunciadamente concordo com a afirmação de que as partículas materiais, não obstante pequenas que sejam, não poderiam ser enformadas e reunidas de uma tal forma que produzam percepção: vendo que grandes partículas não poderiam fazer assim (como é óbvio), e que nas pequenas partículas tudo é proporcional ao que ocorre nas grandes. Locke faz aqui outro ponto importante sobre a matéria, quando ele diz que esta não deveria ser considerada como uma coisa, ou (na minha forma de colocar isto) como uma mônada verdadeira e perfeita, porque ela é somente uma massa contendo infinitamente muitos seres. Neste ponto, ele esteve somente a um passo do meu sistema. Porque o que eu faço é atribuir percepção a toda esta infinidade de seres: cada um deles é como um animal, provido com uma alma (ou algum princípio ativo comparável que faz uma verdadeira unidade), juntamente com o que precisar para ser passiva e ter um corpo orgânico. Estes seres têm recebido sua natureza ativa e sua natureza passiva, isto é, sua característica imaterial e material, da causa universal e suprema (Leibniz, [1704] 1996, IV, x, p. 220).

No caso de tal passagem, o monadismo clássico requer a teoria do dualismo de propriedades, um dualismo de propriedades ativa e passiva da substância simples ou mônada, que é comparável com uma alma. Nesta teoria, estas propriedades são de alguma forma recebidas de Deus, que tem um papel crucial nas relações mente-corpo, tal como lêse na passagem clássica sobre a harmonia pré-estabelecida entre as mônadas criadas.

Embora em minha opinião a dificuldade sobre a união entre a alma e o corpo foi agora removida, outras dificuldades permanecem. Eu tenho demonstrado a posteriori, através da harmonia pré-estabelecida, que todas as mônadas foram criadas por Deus como dependendo dele, ainda assim, não posso entender em detalhe como isto é feito; e basicamente a preservação das mônadas é nada mais do que uma criação contínua, como os Escolásticos bem sabiam (Leibniz, [1704] 1996, IV, x, p. 223).

Eu afirmaria que, no monadismo contemporâneo, estas propriedades seriam mais propriedades dos elementos, sendo os elementos postulados para fins de argumentação.

Contudo, no contexto da ontologia da mente, a postulação não tem compromisso com a existência de um Ser Supremo (este poderia ser perfeitamente o caso da 
argumentação a favor de uma teologia natural das mônadas). A harmonia a priori da relação psicofísica merece ser preservada na abordagem contemporânea do monadismo.

As observações descritas até aqui são suficientes para estabelecer algumas diferenças e semelhanças entre os monadismos clássico e contemporâneo. Existem outras diferenças para considerar, especialmente aquelas relacionadas com a fenomenologia e com o fechamento causal das mônadas, um ponto que tem sido questionado nos monadismos contemporâneos, os quais discutirei brevemente na seção V.4.

Seria mister salientar, por fim, outra diferença entre o monadismo clássico e qualquer consideração em prospecto de uma monadismo contemporâneo. Tal diferença é relativa à noção de representação, ou das capacidades representacionais das mônadas. Esta capacidade é concisamente explicada por Leibniz na seguinte passagem:

Nós aumentaríamos a semelhança postulando que existe uma tela neste quarto escuro que recebe imagens, e esta tela ou membrana não é uniforme mas diversificada em pastas representando itens do conhecimento inato; tal tela está sob tensão, dando uma espécie de elasticidade ou força ativa e age (ou reage) de maneiras que são adaptadas tanto a velhas pastas quanto às novas, surgidas com as imagens novas que chegam. Esta ação consistiria em certas vibrações ou oscilações, tais como aquelas que vemos quando uma corda que está sob tensão é tocada e dá uma espécie de som musical [...] Esta analogia explicaria razoavelmente o que acontece no cérebro. Quanto à alma, que é a substância simples ou mônada, sem ser estendida, ${ }^{73}$ ela representa estas diversas massas extensas e tem percepções delas (Leibniz, [1704] 1996, II, xi, p. 56).

Os poderes representacionais são ativos, o que é, em parte, contrário à imagem lockeana da sala escura para descrever o entendimento humano (tal como na imagem humeana), onde a faculdade de representação parece ser absolutamente passiva, tal como

\footnotetext{
${ }^{73}$ Neste ponto, Leibniz assere que a mônada não é extensa. Entretanto, dado que a mônada é composta de uma parte material, pode-se argumentar que ela tenha extensão, ainda que imperceptível. Portanto, a monadologia tem a ver com a questão da mente extensa ou mente estendida, proposta por Clark \& Chalmers (1998) na literatura de filosofia da mente recente. Pretendemos desenvolver este ponto em ulteriores trabalhos.
} 
numa apresentação interna de um objeto externo. Num certo sentido, o conceito moderno de mônada parece estar ligado ao poder ativo. No sentido contemporâneo, este poder de representação parece ser aumentado e também parece incluir o aspecto intersubjetivo da representação, o que pressupõe alguma abertura nas janelas fechadas das mônadas leibnizianas, ou seja, a habilidade de representar as representações de outras mônadas. Minha modesta contribuição para o debate sobre as mônadas diverge do monadismo leibniziano neste ponto.

Eu agora considero outra forma de monadismo que tem sido discutida em relação às ciências especiais: a teoria das entidades atuais de Whitehead, que são mônadas.

\section{2 - Whitehead}

Uma concepção de monadismo digna de nota, que é chamada de "cosmologia monádica", foi desenvolvida por Alfred North Whitehead, e é frequentemente mencionada por sua forte relação com os fundamentos da física, principalmente, com os fundamentos da mecânica quântica.

Whitehead parte de uma interessante filosofia especulativa por meio de uma doutrina ontológica que é definida por meio da noção de "esquema categorial", na tradição do pensamento filosófico por meio de categorias. Com relação a estas, Whitehead propôs três: a categoria dos últimos, categorias da existência ou ontológicas, e categorias da explicação ou metodológicas. A par das categorias, ele definiu as regras de aplicação das categorias à realidade, ou obrigações categoriais. Relevante para o propósito de caracterizar 
o seu monadismo clássico, abordardaremos brevemente o esquema categorial ontológico de sua teoria monadológica.

Para começar, é crucial examinar o conceito de substância na filosofia do organismo de Whitehead, de acordo com a qual o universo é composto de uma multiplicidade de unidades chamadas de "entidades atuais". De acordo com Whitehead:

Entidades atuais - também chamadas "ocasiões atuais" - são as coisas reais finais das quais o mundo é feito. Não há como ir além das entidades atuais para achar algo mais real [...] existem gradações de importância e diversidade de função, ainda que nos princípios, que a atualidade exemplifica, todos estão no mesmo nível. Os fatos finais são todos semelhantes, entidades atuais; e estas entidades atuais são gotas de experiência [drops of experience], complexas e interdependentes (Whitehead, [1929] 1985, p. 18).

As entidades fundamentais são também denominadas "res verae", um termo que

Whitehead emprestou de uma interpretação específica da teoria da mente de Descartes (surpreendentemente) $^{\mathbf{7 4}}$. Ao considerar as entidades atuais como as realidades finais, Whitehead compara sua doutrina monadista com a de Leibniz em muitas passagens. Por exemplo:

A filosofia do organismo, em seu esquema de um tipo de entidades atuais, adota a visão que a abordagem de Locke da substância mental incorpora, de uma forma muito especial, uma derivação filosófica mais penetrante do que a abordagem de Descartes da substância corporal. Não obstante, a abordagem de Descartes deve achar seu lugar no esquema filosófico. No conjunto, esta é a moral a ser tirada da monadologia de Leibniz. Suas mônadas são melhor concebidas como generalizações das noções contemporâneas de mentalidade. As noções contemporâneas de corpos físicos somente entram em sua filosofia subordinada e derivadamente. A filosofia do organismo empreende manter a balança mais

\footnotetext{
${ }^{74}$ Whitehead se refere à doutrina cartesiana da substância verdadeira, as res verae, inspirado nesta passagem do conhecido trabalho de Descartes, Meditações Metafísicas, que foi citado por Whitehead, e que eu cito aqui em parte: "Ao mesmo tempo, eu devo lembrar que sou um homem, e consequentemente tenho o hábito de dormir, e meus sonhos representam a mim as mesmas coisas ou algumas vezes coisas menos prováveis do que àqueles que são insanos em seus momentos de sanidade [...] ao mesmo tempo devemos pelo menos confessar que as coisas que são representadas em nós em sono são como representações pintadas que somente podem ter sido formadas como contrapartes de algo real e verdadeiro".
} 
equilibrada. Mas isto começa com a generalização da abordagem de Locke das operações mentais (Whitehead, [1929] 1985, p. 19).

De acordo com esta passagem, foi intenção de Whitehead "deixar a balança mais equilibrada", isto é, em minha visão, ele intentou salientar o importe ontológico da mentalidade (ou de sua contraparte real), como requer a tese de essencialismo real já abordada na defesa da tese ontológica que proponho, e da materialidade, isto é, o mental e o físico teriam o mesmo importe ontológico na constituição das entidades atuais.

Depois de definir a entidade ontológica básica, a entidade atual, Whitehead discorre sobre as categorias da explicação de seu sistema cosmológico, cujo aspecto básico está na relação entre as entidades atuais, o nexus, uma categoria básica da explicação, que é definida desta forma: "um nexus é um conjunto de entidades atuais na unidade da relação constituída por suas 'preensões' [prehensions] (representações subjetivas recíprocas) umas das outras" (Whitehead [1929] 1985, p. 24). O processo mais básico do universo é o do devir, ou vir-a-ser (becoming) uma entidade atual, um processo puramente criativo. Comentando sobre a teoria organísmica do continuum extensivo, Whitehead explica que:

O campo físico e, desta forma, atomizado com divisões definidas, ele se torna o nexus de atualidades. Tal quantum (isto é, cada divisão atual) do contínuo extensivo é uma fase primária da criatura. O quantum é constituído por sua totalidade de relações e não pode mover-se. A criatura também não tem quaisquer aventuras externas, mas somente a aventura interna de vir-a-ser [becoming]. Seu nascimento é seu fim. Esta é uma teoria de mônadas, mas esta difere da teoria de Leibniz no ponto em que se afirma que suas mônadas mudam. Na teoria orgânica, elas meramente vêm a ser. Cada criatura monádica é um modo do processo de sentimento [feeling] do mundo, de alojamento do mental em uma unidade de sentimento complexo, de todo modo determinado. Tal unidade é uma "ocasião atual": é o derivativo último do processo criativo (Whitehead, [1929] 1985, p. 80).

Convém observar, antes de prosseguir, que há algumas imprecisões nas afirmações de Whitehead sobre Leibniz. Primeiramente, deve-se observar que as monadas de Leibniz 
não "mudam", ao contrário dos fenômenos do mundo sensível, mas são condições de toda mudança fenomênica. Neste ponto, contrariamente ao que é afirmado no trecho acima, as propriedades monádicas concebidas por Whitehead são bastante semelhantes às de Leibniz.

Não obstante esta similaridade com a doutrina leibniziana, a teoria acima descrita é ressaltada na medida em que a monadologia inclui aspectos que merecem ser notados como adequados para o pensamento científico contemporâneo e absolutamente apropriado como uma pressuposição metafisica da física atual, uma metafísica que poderia ser baseada numa imagem do universo na qual as unidades básicas do campo relativístico quântico são unidades monádicas. Cada mônada whiteheadiana, a unidade básica do quantum extensivo, é uma entidade atual, unidade fundamental da realidade, as res verae, as verdadeiras substâncias do universo. A mônada whiteheadiana é definida para ter polos que são definidos como metades temporais, uma mental e outra física, tal como lemos nesta forma de dualismo polar: "O polo mental se origina como uma contraparte conceitual das operações no polo físico. Os dois polos são inseparáveis em sua origem. O polo mental começa com o registro conceitual do polo físico [...] Cada entidade atual está 'no tempo', na medida em que seu polo físico é considerado, e 'fora do tempo', na medida em que seu polo mental é considerado" (Whitehead, [1929] 1985, p. 65). E a teoria polar da relação do físico-para-o-mental na mônada whiteheadiana é expressa de tal forma que é contrastada com o dualismo cartesiano. Ele escreve:

Cada atualidade é essencialmente dipolar, física e mental, e a herança física é essencialmente acompanhada por uma reação conceitual parcialmente conformada a esta, e parcialmente introdutória de um contraste relevante novo, mas sempre introduzindo ênfase, valoração e propósito. A integração do lado físico e do lado mental numa unidade de experiência é uma auto-formação que é um processo de concrescência, e pelo qual o 
princípio de imortalidade objetiva caracteriza a criatividade que a transcende. Então, ainda que a mentalidade seja não-espacial, a mentalidade é sempre uma reação de, e integração com, a experiência física, que é espacial (Whitehead, [1929] 1985, p. 110).

Assim, cada mônada é composta de mentalidade e de fisicidade por meio de um processo contínuo do ser, isto é, o processo de vir-a-ser das mônadas ou entidades atuais, e o processo de vir-a-ser é chamado concrescência. Em outra passagem de suas explicações, a mônada whiteheadiana é concebida como tendo os polos físico e mental como sentidos (feelings) que são vistos como primários, originários.

Considerando aqui a teoria de Whitehead, talvez seja difícil classificá-la como uma teoria clássica de monadismo, pois existem muitas características que a fazem ser semelhante a uma teoria contemporânea de mônadas. A principal característica é a interrelação entre as entidades atuais, sendo a inter-relação entre as mônadas chamada por Whitehead de "solidariedade". De acordo com a teoria do contínuo físico, existe um contínuo que é explicado como se segue:

Um continuum extensivo e um complexo de entidades unidas por várias relações aliadas de todo e parte, e de entrelaçamento de tal modo a possuir partes comuns, e de contato e de outras relações derivadas destas relações primárias. A noção de um contínuo envolve tanto a propriedade de divisibilidade indefinida quanto a propriedade de extensão ilimitada [...] Este continuum extensivo exprime a solidariedade de todos os pontos de vista possíveis através de todo processo do mundo (Whitehead, [1929] 1985, pp. 66-7).

De acordo com tal passagem, existe a possibilidade da união solidária das entidades atuais que atomizam fisicamente o continuиm. O continuиm é preenchido com mônadas whiteheadianas solidárias entre si. Estas mônadas não estão, desta forma, "fechadas" sensivelmente $a b$ initio como as mônadas leibnizianas. A característica do mônadismo whiteheadiano a torna absolutamente contemporânea em comparação com o 
monadismo leibniziano. Existem conexões entre as entidades atuais e, portanto, existem claramente janelas nas mônadas whiteheadianas. Esta característica é adequada para tratar do fato filosófico contemporâneo da intersubjetividade fenomenológica. 


\section{Capítulo V}

\section{Objeções ao Monadismo}

Nesta parte, eu gostaria de colocar quatro grupos de objeções contra o argumento em favor do monadismo ou substancialismo esboçado neste ensaio. Tais objeções foram colhidas de "bouches des philosophes" (como já se afirmou nos ensaios de filósofos modernos, como Descartes e Spinoza), com os quais o autor tem se correspondido ao longo do período de pesquisa. Tais objeções atingem diversos pressupostos aceitos neste ensaio, pressupostos estes que destacarei ao logo das réplicas às objeções propostas. O primeiro grupo tem a ver com o debate sobre a existência e conhecimento dos universais, tal como este foi claramente explicado por Russell, em suas célebres notas sobre os problemas centrais da filosofia. O segundo grupo questiona a contemporaneidade da abordagem monadista das relações mente-corpo. O terceiro alude a uma distinção necessária entre elementos e propriedades, com o fito de responder a objeções que eu chamo de "lógicoempiricistas”. O quarto grupo refere-se à questão da abertura causal da mônada.

\section{1 - Objeções sobre as Formas ou Universais}

Para começar, pode-se questionar a aparente trivialidade da questão acerca do significado do termo "mônada" ou substâncias simples. Por "trivialidade" pode-se entender que a propriedade de ser uma mônada seria aplicável a toda espécie de indivíduo, em todo mundo possível e, neste sentido, uma mônada seria estritamente universal. A monadologia 
considerada como uma doutrina sobre universais já fora aludida por Russell ([1912] 1997, p. 40), o qual escreveu:

A primeira dessas objeções, defendida por Spinoza e sustentada até os dias de hoje por Bradley e muitos outros filósofos é chamada monadismo, porque cada uma dessas coisas isoladas é chamada mônada. Ambas filosofias, opostas como são, resultam, na minha opinião, de uma atenção indevida a uma espécie de universais, por exemplo, a variedade representada por adjetivos e substantivos, mais do que por verbos e preposições.

A questão dos universais é amplamente discutida na tradição analítica e certamente tem a ver com nossa discussão sobre as relações mente-corpo. Entendo aqui certamente a noção de "monada" como "individuum", em isolamento parcial sensível uns dos outros, mas apenas de um ponto de vista da sensibilidade empírica. Em se afirmando que a mônada seria um universal, estamos nos referindo não à situação puramente empírica pressuposta pela tradição analítica, mas como uma forma de ver o mundo por meio de universalidades, por meio de conceitos e categorias, não estando tais universais, por assim dizer, nas coisas. Tal modo de argumentar foi denominado "transcendental" por Strawson, e me parece bastante adequado à proposta monadista, uma vez que admite-se que o conhecimento provém não somente da experiência sensível, mas tambem de fontes a priori, fontes estas que podem ser denominadas "esquemas conceituais" subjetivos do mundo objetivo.

Dessa forma, conforme o trecho acima, podemos considerar a visão advogada neste ensaio - o monadismo - como uma teoria sobre a realidade dos universais - uma teoria realista e não-nominalista - com argumentação transcendental no sentido de Strawson e, também, de Goodman (isto é, não ignorando a contribuição de nosso próprio esquema conceitual na descrição do mundo). 
Em minha concepção de mônada, o indivíduo seria uma mônada em mundos definidos holisticamente, segundo lógicas modais nas quais o todo tem prioridade sobre as partes, isto é, lógicas nas quais não se aceita o princípio de extensionalidade mereológica clássica, tal como vimos nas premissas composicionais do argumento central em favor da tese monadista.

\section{2 - Dualismo Elementar: Categorias e Elementos}

Há objeções que atacam a ontologia dualista do argumento proposto e que envolve a noção de "erro de categoria". Tal classe de objeções, lideradas na tradição analítica na linha de Ryle (1949) e seus seguidores mais recentes, coloca a objeção nos seguintes termos:

Eu registro seu ponto que a assunção deste ponto de vista evita muitos problemas associados com a superveniência e com a emergência. Mas sua assunção bruta parece incoerente per se, ao herdar a problematica mente/materia (a qual Schopenhauer elegantemente denominou "nó mundial" [Weltknoten]). Como podem incompatibilidades categoriais - mente e matéria - serem relata?

Minha resposta à objeção acima, feita em correspondência pessoal por Gordon Globus (2006), que questiona a assunção de dualismo elementar, é que deve-se distinguir entre relações ontológicas de "elementos" e de "categorias", conforme alguns autores têm argumentado. Os elementos não são categorias que possam ser dispostas em pares contraditórios, tais como se argumenta a la Ryle, "mente inextensa / matéria extensa", sugerindo um dualismo substancial cartesiano, mas sim pares contrários na forma de suas propriedades mentais e físicas, constituindo, dessarte, um dualismo de propriedades. 
Semelhante objeção aparece em outro momento da crítica: "Tal como sua tese coloca, certas vexações filosóficas são dissolvidas [melt down] na estrutura monadológica [...] Isto não seria justificativa suficiente e não vejo como nossa vida filosófica tornar-se-ia mais fácil.”

O autor sugere que o monadismo seria uma forma de solução cabal, que resolve problemas filosóficos sem se apresentar como um sistema explicativo. Creio, porém, que este ensaio mostrou como diversos problemas filosóficos podem ser resolvidos com o dualismo elementar das mônadas.

\section{3 - Monadismos Clássico e Contemporâneo}

Uma objeção relevante contra o monadismo, que se pode imaginar inicialmente, tem a ver com a adequação da noção de mônada para o filosofar contemporâneo sobre o problema mente-corpo. Com relação a isto, é pertinente responder que a concepção aqui proposta difere consideravelmente das doutrinas que eu tenho chamado de "monadismos clássicos", que são representadas pela teoria de Leibniz e, parcialmente, a de Whitehead (sendo a teoria de Whitehead mais difícil de classificar como uma teoria clássica de mônadas).

Eu defini algumas diferenças sutis, principalmente as diferenças com relação à teoria da causação mental eficiente que, no meu caso, apóia um argumento para a inclusão causal eficiente da mente. Na visão esboçada aqui, as mônadas são concebidas como sendo causalmente correlacionadas, em oposição ao fechamento causal das mônadas clássicas. 
Ademais, como uma sugestão de que o monadismo pode ser revisitado contemporaneamente, é relevante responder que alguns autores têm explorado uma nova monadologia física, pode ser vista como fundante de uma visão paradigmática de mundo, a qual posso chamar de oculo vel conspicillum monadicum, de fato uma "cosmologia monádica" no dizer de matemáticos como Whitehead e Euler, visão esta que pode propor avanços metafísicos na abordagem de questões alusivas aos fundamentos da física contemporânea. ${ }^{75}$ Há também interpretações da Física Quântica que atribuem uma protomentalidade aos fenômenos atômicos, tal como propostos em vários argumentos das ainda controversas Quantum Mind Theories. Acredito, embora não tenha espaço para defender na íntegra aqui, que o monadismo pode assumir uma feição contemporânea e, talvez, contribuir com avanços significantes na compreensão de certos fenômenos naturais investigados pelas ciências especiais.

Posso ainda acrescentar como sugestivo da contemporaneização da monadologia clássica as teorias biológicas contemporâneas que debatem o que seriam os princípios da vitalidade dos seres vivos. Tal debate é amplamente discutido na Filosofia da Biologia Moderna. Em vários de seus escritos, muitos deles ainda inéditos, Leibniz, descreve as mônadas como vires, ou enteléquias vitais, ou princípios vitais, noções que foram posteriormente retomadas pela escola vitalista de Driesch $^{76}$ e outros biólogos

\footnotetext{
${ }^{75}$ Existem alguns trabalhos científicos contemporâneos que exploram esta questão. Ver, por exemplo, Nakagomi (2004).

${ }^{76}$ O leitor deve consultar a interessante obra Driesch (1908).
} 
contemporâneos do desenvolvimento dos seres vivos, como nas teorias dos campos mórficos que defendem a tese vitalista no campo da explicação dos fenômenos vitais ${ }^{77}$.

Por fim, para defender a importância contemporânea do monadismo como teoria ontológica contemporânea na filosofia da mente, podemos considerar a relevância do monadismo para as questões em psicologia, que é uma outra ciência especial. Em certos momentos de sua filosofia, Leibniz vê a mônada como elemento da subjetividade do "ego", ao que ele denominou de mônada-ego. Esta visão, de certa forma, lançou as bases do que se pode chamar contemporaneamente de ego ou de consciência subjetiva. Semelhante monadologia também, e de forma muito mais adequada à Psicologia contemporânea, foi desenvolvida por Husserl ([1931] 1988).

\section{4 - Discussão sobre a Janela das Mônadas}

Em correspondência pessoal, a filósofa Cristina Schneider, da Ludwig-Maxmilians Universität de Munique, apresentou mais algumas objeções à proposta do monadismo elementar.

Sua objeção principal refere-se à questão da abertura causal da mônada (a questão leibniziana da "janela da mônada"), isto é, da possibilidade das mônadas estarem não somente no plano suprasensível (entre os planos inteligível e sensível), mas também em relação causal com o mundo físico. Segundo Schneider (2009), a minha noção de

\footnotetext{
${ }^{77}$ O leitor que atua no campo da filosofia da biologia, da medicina ou ainda o biólogo ou mesmo o médico vitalista, homeopata ou não, pode consultar a recentemente lançada obra sobre a filosofia leibniziana da medicina, em Smith (2011).
} 
causalidade (apresentada na seção IV.2, no item referente à Harmonia Estabelecida) não é clara, obscuridade esta que ela atribui também a muitas das discussões contemporâneas.

Segundo ela, é preciso distinguir um sentido de causa como relação nomológica (lawlike) de um sentido como capacidade de geração (bringing about). Leibniz defenderia apenas a primeira espécie de causalidade, que seria uma forma de causa final. Segundo ressaltado por ela, no sistema leibniziano, as mônadas estariam em relação causal umas com as outras, mas não se trata de uma causalidade eficiente, mas sim de uma causalidade final. Concordo com esta interpretação. Por causa final, entende-se uma relação de mudança de propriedades que ocorre apenas no mundo inteligível, o qual está fora do mundo sensível. Ela também lembra que Leibniz não tem um discurso de instanciação de propriedades (do geral para o particular), uma vez que todo indivíduo é universal. Segundo ela, "qualquer coisa é individual", e eu estaria dando muita importância ao aspecto genérico.

Em minha resposta, concordo parcialmente com a teoria da relação de instanciação, posto que a concepção de mônada que proponho, como abertura causal sensível, permite a alegação de que a mônada seja particular, uma vez que o sensível restringe-se ao particular e não ao universal (não existe percepção sensível universal, conforme argumentou Russell).

Uma segunda crítica de Schneider à minha versão anterior desta tese foi a presença excessiva de fórmulas lógicas, sem que elas funcionassem para a derivação de um teorema. A sua presença não reforçava a minha argumentação, e elas seriam apenas paráfrases das minhas intuições, já expostas em linguagem natural. Aceitei esta crítica, formulada também por minha banca de qualificação, e eliminei este recurso à notação lógica, deixando para um trabalho futuro a formulação lógica das teses de ontologia e mereologia que descrevem a relação mente-corpo. 


\section{Considerações Finais}

Neste ensaio, consideramos detidamente o debate contemporâneo sobre o problema mente-corpo no contexto da tradição analítica, relativo às dificuldades da emergência e da causação mental, tão preciosas para o fisicismo não-reducionista. Elaborando algumas conclusões para esta discussão, gostaria de afirmar que a teoria de mônadas e o atual fisicismo não-reducionista são doutrinas reconciliáveis (em parte). Tal reconciliação é possível se se questionar o conceito de matéria física pressuposto por muitos fisicistas, dando ao conceito resultante uma imagem que é compatível com as recentes explorações efetuadas nos fundamentos da física quântica.

A noção e o significado do termo "físico" desempenham um papel central na discussão do problema mente-corpo. Tal como ela figura no fisicismo contemporâneo, esta noção pressupõe uma concepção extensiva de substancialidade, ou seja, a concepção de matéria física é atualmente muito semelhante à concepção cartesiana de fisicidade, que excluiu a noção de mental. Os argumentos de superveniência e de emergência não podem evitar diretamente o problema da exclusão causal porque a mente está excluída. Este me parece ser o ponto crucial dos debates contemporâneos sobre mente e corpo.

Alego, em contrapartida, que o fisicismo é compatível com uma noção intensiva de substância, tal como é pressuposta pelo monadismo. Tal seria um fisicismo "neutro", compatível com monadismo por meio de uma teoria de múltipla atualização da forma monádica das mônadas fundamentais que são, segundo nossa proposta, os constituintes últimos da realidade. 


\section{Referências Bibliográficas}

Aristóteles (2001), The Basic Works of Aristotle. Org. por R. McKeon. New York: Modern Library.

Armstrong, D.M. (1989), Universals: An Opinionated Introduction. Boulder: Westview Press, 1989.

Block, N. (1990), "Can the Mind Change the World?", in Boolos, G. (org.), Meaning and Method. Cambridge: Cambridge University Press.

(2003), "Do Causal Powers Drain Away?", Philosophy and Phenomenological Research 67: 133-50.

Bochman, A. (1990), "Mereology as a Theory of Part-Whole", Logique et Analyse 129130: 75-101.

Bontly, T.D. (2002), “The Supervenience Argument Generalized”, Philosophical Studies 109: 75-96.

Broad, C.D. (1925), “The Mind and its Place in Nature”. London: Routledge and Kegan Paul.

Bruno, G. (1591). De monade, numero et figura liber, Frankfurt: Wechelum \& Fischerum.

Burkhardt, H. \& Degen, W. (1990), "Mereology in Leibniz's Logic and Philosophy", Topoi 9: 3-13.

Byrne, A. (1999), “Cosmic Hermeneutics”, Philosophical Perspective 13: 347-84.

Chalmers, D.J. (1996), The Conscious Mind: In Search of a Fundamental Theory. Oxford: Oxford University Press.

Clark, A. \& Chalmers, D.J. (1998), “The Extended Mind”, Analysis 58: 10-23.

Clay, R.E. (1974), "Relation of Leśniewski’s Mereology to Boolean Algebra”, Journal of Symbolic Logic 39: 638-48.

Cooper, W. (2010), Loosing Our Mind: Some Challenges Confronting the Explanation of Mental Autonomy in the Physical World. Lexington: Verlag Dr. Muller.

Crane, T. (2003), "Mental Causation", Philosophy of Mind: Lecture Notes at the University College London.

Crisp, T.M. \& Warfield, T.A. (2001), “Kim’s Master Argument”, Noûs 35: 304-16. 
Davidson, D. (1970) "Mental events", in Foster, L. \& Swanson J.W. (orgs), Experience and Theory. Amherst: University of Massachussets Press, pp. 79-101. Republicado em Davidson, Essays on Action and Events. Oxford, Clarendon Press, 1980, pp. 207-27. (1985), "Replies to Essays X-XII”, in: Verzeman, B. \& Hintikka, M.B. (orgs). Essays on Davidson: Action and Events. Oxford: Clarendon Press, pp. 242-52.

(1999), "The Emergence of Thought”, Erkentnis 51:7-17.

Drai, D. (1999), Supervenience and Reality. Farnham (England): Ashgate.

Driesh, H.A.E. (1908), The Science and the Philosophy of Organism. Gifford Lectures for 1907. London: Adam \& Charles Black.

Eliot, T.S. (1916), “The Development of Leibniz’s Monadism”. Monist 26: 534-56.

Endicott, D. (1994), “Constructival Plasticity”, Philosophical Studies 74: 51-75.

Esfeld, M. (1998), "Holism and Analytic Philosophy", Mind 107: 365-80.

(2001), Holism in Philosophy of Mind and the Philosophy of Physics. Dordrecht: Kluwer.

Fodor, J.A. (1989), “Making Mind Matter More”, Philosophical Topics 17: 59-79.

Garber, D. (2009), Leibniz: Body, Substance and Monad. New York: Oxford University Press.

Gibbard, A. (2003), “Thoughts and Norms”, Philosophical Issues 13: 83-98.

Gillett, C. (2002), "Strong Emergence as a Defence of Non-Reductive Physicalism: A Physicalist Metaphysics of 'Downward Determination"”, Principia 6: 89-120.

Hare, R.M. (1984), “Supervenience”, Proceedings of the Aristotelian Society 58: 1-16.

Haugeland, J. (1982), "Weak Supervenience”, American Philosophical Quarterly 19: 93103.

Hawthorne, J.P. (2002), "Blocking Definitions of Materialism”, Philosophical Studies 110: $103-13$.

Heil, J. (1992), The Nature of True Minds. Cambridge: Cambridge University Press.

Horgan, T. (1993), "From Supervenience to Superdupervenience: Attending the Demands of a Material World", Mind 102: 555-86. 
(1982), "Supervenience and Microphysics", Pacific Philosophical Quarterly 63: $28-43$.

Humphreys, O. (1997a), "Emergence, not Supervenience", Philosophy of Science 64 (Proceedings): S337-S354.

(1997b), "How Properties Emerge", Philosophy of Science 64: 1-17.

Husserl, E. ([1931] 1988), Cartesian Meditations. Trad. D. Cairns. Dordrecht: Kluwer.

Jackson, F. (1994), "Armchair Metaphysics", in O'Leary-Hawthorne, J. \& Michael, M. (orgs.), Philosophy in Mind. Dordrecht: Kluwer, pp. 23-42.

Jackson, F. \& Pettit, P. (1990), "Program Explanation: A General Perspective", Analysis 50: 107-17. Republicado in Jackson, F.; Pettit, P. \& Smith, M. (2004), Mind, Morality, and Explanation: Selected Collaborations. Oxford: Oxfrod University Press.

Kant, I. ([1785] 1980), Fundamentação da Metafísica dos Costumes, in Os Pensadores: Kant (II), trad. de P. Quintela. São Paulo: Abril Cultural, pp. 101-62.

(2003), "Physical Monadology", trad. D. Walford \& R. Meerbote, in Theoretical Philosophy (1755-1770). The Cambridge Edition of the Works of Immanuel Kant in Translation. Cambridge: Cambridge University Press.

Kim, J. (1976), "Causality, Identity and Supervenience in the Mind-Body Problem", Midwest Studies in Philosophy 4: 31-76.

(1982), "Psychophysical Supervenience as a Mind-Body Theory", Cognition and Brain Theory 5(2): 129-47.

(1992), “'Downward Causation' in Emergentism and Non-Reductive Physicalism", in Beckermann, A.; Flohr, H. \& Kim, J. (orgs.), Emergence or Reduction? Essays on the Prospects of Nonredutive Physicalism. Berlin: Walter de Gruyter, pp. 119-38.

(1993), Supervenience and Mind: Selected Philosophical Essays. Cambridge: Cambridge University Press.

(1998), Mind in a Physical World: An Essay on the Mind-Body Problem and Mental Causation. Cambridge (EUA): MIT Press.

- (1999), "Making Sense of Emergence", Philosophical Studies 95: 3-36.

(2000), "How Can my Mind Move my Limbs? Mental Causation from Descartes to Contemporary Physicalism", Philosophical Exchange 30: 5-16. 
(2003), "Blocking Causal Drainage and Other Maintenance Chores with Mental Causation", Philosophy and Phenomenological Research 67: 151-76.

(2005), Physicalism or Something Near Enough. Princeton: Princeton University Press.

Latta, R. (1898), "Introduction", in Leibniz, G.W. The Monadology and other Philosphical Writings, trad. R. Latta. Oxford: Clarendon Press, pp. 1-211.

Leibniz, G.W. ([1704] 1996), New Essays on Human Understanding, trad. F. Remanat \& J.F. Bennett. Cambridge: Cambridge U. Press. Em português: Novos Ensaios sobre $o$ Entendimento Humano, in Os Pensadores, trad. L.J. Baraúna. São Paulo: Abril Cultural, 1974.

([1714] 1974), Monadologia, in Os Pensadores, trad. M.S. Chauí Berlinck. São Paulo: Abril Cultural.

(1966), Opuscules et Fragments Inédits de Leibniz, org. por L. Couturat. Munich: Georg Olms.

(1969), Philosophical Papers and Letters, org. por L. Loemker. Dordrecht: Reidel.

Levine, J. (1983), "Materialism and Qualia: The Explanatory Gap", Pacific Philosophical Quarterly 64: 354-61.

Lewis, D. (1966), “An Argument of Identity Theory”, Journal of Philosophy 63: 17-25. (1986) On the Plurality of Worlds. Oxford: Blackwell. (1991), Parts of Classes. Oxford: Blackwell.

Lotze, H. (1885), Microcosmus: An Essay Concerning Man and His Relation to the World, trad. E. Hamilton \& E.E.C. Jones. Edinburgh: T. \& T. Clark.

Mates, B. (1994), The Philosophy of Leibniz: Metaphysics and Language. Oxford: Oxford University Press.

MacLennan, B.J. (1996), "The Elements of Consciousness and Their Neurodynamical Correlates". In: Journal of Consciousness Studies 3: 409-24. Republicado in: Shear, J. (org.) (1998), Explaining Conciousness: The "Hard" Problem. Cambridge (EUA): MIT Press, pp. 249-66.

McLaughlin, B. (1996), "Varieties of Supervenience", in Savellos, E. \& Yalçin, U. (orgs.), Supervenience: New Essays. Cambridge: Cambridge University Press, pp. 16-59. 
Mill, J.S. ([1843] 1979), Sistema de Lógica Dedutiva e Indutiva, tradução incompleta in Os Pensadores, trad. J.M. Coelho. São Paulo: Abril Cultural.

Miller, R.B. (1990), "Supervenience is a Two-Way Street”, Journal of Philosophy 87: 685701.

Nagel, E. (1961), The Structure of Science. New York: Routledge \& Kegan Paul, New York.

Nagel, T. (1986), The View from Nowhere. Oxford: Oxford University Press.

Nakagomi, T. (2004), "Quantum Monadology and Consciousness", in Globus, G.; Pribram, K. \& Vitiello, G. (orgs.), Brain and Being: At the Boundary between science, philosophy, language and arts. Amsterdam: John Benjamins, pp. 111-26.

Nasrin, M. (2000), “Multiple Realizationism: Also a Difficult of Functionalism”, Journal of Coniousness Studies 7: 25-34.

Oderberg, D. (2007), Real Essentialism. New York: Routledge.

Osei, J. (1994), "Karl Popper Proposed Solution to the Freewill-Determinism Paradox: Freewill or Compatibilism?", International Journal of Applied Philosophy 8: 39-48.

Papineau, D. (2001), "The Rise of Physicalism", in Gillett, C. \& Lower, B. (orgs.), Physicalism and its Discontents. Cambridge: Cambridge University Press, pp. 3-36. (2003), "Aspects of the Mind-Body Problem". Philosophy of Mind Seminars at King's College London.

Pessoa Jr., O. (2010), "Reducionismo e o Experimento Mental de Duplicação Humana", Revista de Filosofia Aurora 22: 69-81.

Pihlström, S. (2002), “The Re-Emergence of the Emergence Debate”, Principia 6: 131-81.

Putnam, H. (1967), "Psychological Predicates", in Capitan, W.H. \& D.D. Merrill, D.D. (orgs.), Art, Mind, and Religion. Pittsburgh: Pittsburgh University Press, pp. 37-48. Republicado como "The Nature of Mental States", in Putnam (1975), Mind, Language, and Reality: Philosophical Papers, vol. 2. Cambridge: Cambridge University Press, pp. 429-40.

(1975), "Philosophy and our Mental Life", in Putnam (1975), Mind, Language, and Reality: Philosophical Papers, vol. 2. Cambridge: Cambridge University Press, pp. 134-43.

(1999), The Threefold Cord: Mind, Body and World. New York: Columbia University Press. 
Rutherford, D. (1995), Leibniz and the Rational Order of Nature. Cambridge: Cambridge University Press.

Russell, B. (1912), "The World of Universals", in Russell, The Problems of Philosophy. Oxford: Oxford University Press, cap. IX. Republicado in Mellor, A.D. \& Oliver, A. (orgs), Properties. New York, Oxford University Press, 1997, pp. 45-50.

Ryle, G. (1949), The Concept of Mind. London: Hutchinson.

Savellos, E. \& Yalçin, U. (orgs.) (1996), Supervenience: New Essays. Cambridge: Cambridge University Press.

Savile, A. (2000), Leibniz and the Monadology. Routledge Philosophy Guidebooks. London: Routledge.

Schneider, C. (2009), “Comments to Elementary Monadism”. Correspondência pessoal.

Schröder, J. (2007), "Mental Causation and the Supervenience Argument", Erkenntnis 67: 221-37.

Seager, W. (1995), "Conciousness, Information, and Panpsychism", Journal of Consciousness Studies 2: 272-88. Republicado in: Shear, J. (org.) (1998), Explaining Conciousness: The "Hard" Problem. Cambridge (EUA): MIT Press, pp. 269-96.

Shoemaker, S. (1980), "Causality and Properties", in van Inwagen, P. (org.), Time and Cause. Dordrecht: Reidel, pp. 109-35.

Sider, T. (2003), "What's So Bad About Overdermination?", Philosophy and Phenomenological Research 67: 719-26.

Simons, P. (2003), Parts: A Study in Ontology. Oxford: Oxford University Press.

Smith, E.H.J. (2011), Divine Machines: Leibniz and the Sciences of Life. Princeton: Princeton University Press.

Smuts, I. (1926), Holism and Evolution. London: Macmillan.

Stephan, A. (1992), "Emergence: A Systematic View of its Historical Faces", in Beckermann, A.; Flohr, H. \& Kim, J. (orgs.), Emergence or Reduction? Essays on the Prospects of Nonredutive Physicalism. Berlin: Walter de Gruyter, pp. 25-48.

_ (1999), "Varieties of Emergence", Evolution and Cognition 5: 49-59.

Sturgeon, S. (1998), "Physicalism and Overdetermination", Mind 107: 411-32. 
Teller, P. (1992), “A Contemporary Look at Emergence”, in Beckermann, A.; Flohr, H. \& Kim, J. (orgs.), Emergence or Reduction? Essays on the Prospects of Nonredutive Physicalism. Berlin: Walter de Gruyter, pp. 139-53.

Varzi, A. (2009), "Mereology", in Stanford Encyclopedia of Philosophy, http://plato.stanford.edu/ entries/mereology.

Wedin, M.V. (2000), Aristotle's Theory of Substance: The Categories and Metaphysics Zeta. Oxford Aristotle Studies. Oxford: Oxford University Press.

Wertheimer, M. (1938), "Gestalt Theory”, in Ellis, W.D. (org.), A Source Book of Gestalt Psychology. New York: Harcourt, Brace \& Co., pp. 1-11. Original em alemão: 1925.

Whitehead, A.N. ([1929] 1985), Process and Reality. New York: Free Press.

Wimsatt, W. (1997), "Aggregativity: Reductive Heuristics for Finding Emergence", Philosophy of Science 64 (Proceedings): S372-S384.

Yablo, S. (1992), “Mental Causation”, Philosophical Review 101: 245-80. (2003), “Causal Relevance”, Philosophical Issues 13: 316-28.

Yoo, J. (2008), “New Hope for Non-Reductive Physicalism”, in Hieke, A. \& Leitget, H. (orgs.), Reduction and Elimination in Philosophy and the Sciences: Papers of the 31st International Wittgenstein Symposium. Kirchberg am Wechsel: Austrian Ludwig Wittgenstein Society, pp. 408-11. 